\title{
Malaria and anaemia : the impact on maternal and perinatal outcomes
}

Citation for published version (APA):

Adam, I. (2008). Malaria and anaemia : the impact on maternal and perinatal outcomes. [Doctoral Thesis, Maastricht University]. Datawyse / Universitaire Pers Maastricht. https://doi.org/10.26481/dis.20081106ia

Document status and date:

Published: 01/01/2008

DOI:

10.26481/dis.20081106ia

Document Version:

Publisher's PDF, also known as Version of record

\section{Please check the document version of this publication:}

- A submitted manuscript is the version of the article upon submission and before peer-review. There can be important differences between the submitted version and the official published version of record.

People interested in the research are advised to contact the author for the final version of the publication, or visit the DOI to the publisher's website.

- The final author version and the galley proof are versions of the publication after peer review.

- The final published version features the final layout of the paper including the volume, issue and page numbers.

Link to publication

\footnotetext{
General rights rights.

- You may freely distribute the URL identifying the publication in the public portal. please follow below link for the End User Agreement:

www.umlib.nl/taverne-license

Take down policy

If you believe that this document breaches copyright please contact us at:

repository@maastrichtuniversity.nl

providing details and we will investigate your claim.
}

Copyright and moral rights for the publications made accessible in the public portal are retained by the authors and/or other copyright owners and it is a condition of accessing publications that users recognise and abide by the legal requirements associated with these

- Users may download and print one copy of any publication from the public portal for the purpose of private study or research.

- You may not further distribute the material or use it for any profit-making activity or commercial gain

If the publication is distributed under the terms of Article $25 \mathrm{fa}$ of the Dutch Copyright Act, indicated by the "Taverne" license above, 
MALARIA AND ANAEMIA

THE IMPACT ON MATERNAL AND PERINATAL OUTCOMES

Ishag Adam 
MALARIA AND ANAEMIA. THE IMPACT ON MATERNAL AND PERINATAL OUTCOMES

\section{Ishag Adam}

ISBN 978-90-5278-778-7

Universitaire Pers Maastricht

๑) Copyright Ishag Adam, Sudan 2008 


\section{THE IMPACT ON MATERNAL AND PERINATAL OUTCOMES}

\section{DISSERTATION}

to obtain the degree of Doctor at the Maastricht University, on the authority of the Rector Magnificus, Prof. dr. G.P.M.F. Mols, in accordance with the decision of the Board of Deans, to be defended in public on Thursday, November 6 2008, at 12.00 hours

Ishag Adam

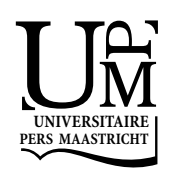




\section{Supervisors:}

Prof. dr. Martin H. Prins

Prof. dr. Mustafa I. Elbashir, Khartoum, Sudan

\section{Assessment Committee:}

Prof. dr. G. Essed (chairman)

Prof. dr. F. Nosten, Oxford, UK

Dr. L. Peeters

Prof. dr. C.P. van Schayck

Prof. dr. N. de Vries

The studies presented in this $\mathrm{PhD}$ dissertation were conducted at Department of Gynaecology of the Medical Faculty of the University of Khartoum, in collaboration with the Department of Epidemiology, Care and Public Health Research Institute, Maastricht University, The Netherlands. 
For the soul of my father, Adam, mercy be upon him, and for my beloved mother, Khadija 



\section{TABLE OF CONTENTS}

$\begin{array}{lll}\text { Chapter } 1 & \text { Introduction }\end{array}$

$\begin{array}{lll}\text { Chapter } 2 & \text { Plasmodium falciparum infection during pregnancy } & 15\end{array}$ in an unstable transmission area in eastern Sudan

$\begin{array}{lll}\text { Chapter } 3 & \text { Prevalence and risk factors for Plasmodium falciparum } & \mathbf{2 5}\end{array}$ malaria in pregnant women of eastern Sudan

Chapter 4 Prevalence and risk factors for anaemia in pregnant women of eastern Sudan

Chapter $5 \quad A B O$ blood group system and placental malaria in an area of unstable malaria transmission in eastern Sudan

Chapter 6 Low body mass index, anaemia and poor perinatal outcome in a rural hospital in eastern Sudan

Chapter 7 Malaria susceptibility and cortisol levels in pregnant women of eastern Sudan

Chapter 8 Perceptions of the causes of malaria and of its complications, treatment and prevention among midwives and pregnant women of eastern Sudan

Chapter 9 General discussion

Summary

Samenvatting

Curriculum vitae

List of publications 

Chapter 1

Introduction 
Around 50 million pregnancies occur in malaria endemic areas every year and approximately half of them occur in sub-Saharan Africa (Steketee et al., 2001). Malaria during pregnancy poses a substantial risk to the mother, her fetus, and the neonate; the infection contributes to maternal anemia, low birth weight infants, and infant mortality (Cot and Deloron, 2003).

Malaria is the major health problem in Sudan (Malik and Khalafalla, 2004). It has been reported that, pregnant Sudanese women are more attractive to the main malaria vector (Himedian et al., 2004a). Malaria is the leading cause of maternal and perinatal mortality in Sudan (Taha et al., 1993; Dafalla et al., 2003; Adam et al., 2004a, Adam and Elbashir, 2004).

Increased susceptibility to malaria in pregnancy is well recognized, and has generally been assumed to be due to hormonal changes resulting in altered immunity (Tian et al; 1998). Just as cerebral malaria results from parasite sequestration in the brain, maternal malaria results from parasite sequestration in the placenta. Parasites adhere to the surface of trophoblastic villi, eliciting the accumulation of inflammatory leukocytes in the intervillous space, and the necrosis of adjacent placental tissue. Maternal malaria results in poor pregnancy outcomes, although the responsible mechanisms have not been defined.

In areas with stable malaria transmission both placental infection and poor outcome decrease in frequency with successive pregnancies; protection may result from control of parasite adhesion, suggesting an attractive target for new therapies/vaccine (Fried and Ouffy, 1998).

Massive chronic intervillositis is an infrequent placental lesion thought to be of immunologic origin composed mainly of monocytes and macrophages and can lead to poor fetal outcome. The villi are characteristically spared; the intervillous spaces appear to be largely obliterated. Increased fibrin deposition and prominent syncytial knots are frequently associated findings. Malaria affect predominantly primigravid women, and is associated with reduced birth weight (Menedez et al., 2001).

While P. falciparum commonly causes anemia in the mother (McGregort 1984; Beeson et al; 2001; Adam et al., 2005a), the frequency of other complications depends on a woman's pre-existing immunity to malaria.

Women in stable malaria transmission (and therefore high immunity) areas are typically asymptomatic (Beeson et al; 2001); among women with incomplete immunity, severe syndromes, such as cerebral malaria and pulmonary edema, frequently occur ( Rasheed et al; 1995; Adam et al., 2004c; Adam and Elbashir, 2004; Adam et al., 2005a; Adam et al., 2005b).

Since the clinical, epidemiological and immunopathological features of malaria during pregnancy vary according to the level of transmission in the area, so the pattern may be different from the results obtained from areas with high transmission.

The presentation of malaria during pregnancy varies according to the pre-existing immunity of the mother. Women living in areas of low transmission have little immunity to malaria which can cause severe syndromes, such as cerebral malaria and pulmonary oedema. In contrast, those who live in areas of stable malaria transmission enjoy greater immunity and experience fewer symptoms during episodes of malaria, although they commonly develop severe anaemia (Brabin, 1983).

Understanding the epidemiology and pathogenesis of malaria during pregnancy provides important insight into relevant immunological processes and facilitates decision on control strategies. Although there are extensive studies in highly endemic African countries, there is no proper published data available for Sudan, which is the biggest African country with a forty million population and $P$. falciparum malaria transmission is unstable in the eastern region (Himedian et al., 2005a; Himedian et al., 2005b). 


\section{OUTLINE OF THIS THESIS}

A longitudinal community- based study was conducted in which pregnant women and nonpregnant controls were followed for one year. In this study we investigated the susceptibility of pregnant women to P. Falciparum malaria in comparison to their non-pregnant counterparts (Chapter 2).

A cross sectional study was conducted, where antenatal clinical attendants were investigated for malaria and anaemia and risk factors for these conditions were assessed.. In this group of patients both the prevalence of malaria and its risk factors (Chapter 3 ) and the prevalence of anemia was and tits risk factors (Chapter 4 ) were descibed.

In a next study, that was cross-sectional, parturient women were investigated for anaemia, peripheral and placental malaria. The prevalence and risk factors for placental malaria in eastern Sudan were descibed (Chapter 5), as well as the effect of malaria and anaemia on maternal and perinatal outcomes (Chapter 6).

A case control study was conducted to investigate the role of cortisol and prolactin in the pathogenesis of malaria (Chapter 7). Finally, in a community- based survey the perceptions among midwives and pregnant women of the causes of malaria, its complications, its treatment and methods of prevention were assessed (Chapter 8 ).

\section{Study area}

The study was performed in New Halfa area in the eastern Sudan. The New Halfa area was constructed in 1964 to settle the inhabitants of old Halfa in the northern border of Sudan who were displaced after construction of the High Dam on the Nile in Southern Egypt. The area itself is made up of similar villages constituting 400000 inhabitants. It is an agricultural area, $500 \mathrm{~km}$ east from Khartoum and $450 \mathrm{~m}$ above sea level, located around $15^{\circ} \mathrm{N} 35^{\circ} \mathrm{E}$. The average annual rainfall is $238 \mathrm{~mm}$ and the average annual relative humidity is $35 \%$. Cotton, sorghum, groundnut, sugar cane and various vegetables are cultivated in about $1700 \mathrm{~km}^{2}$ of the area. There is a permanent irrigation system. The area is characterized by unstable malaria transmission, with peak transmission following the rainy season, which extend usually from September to January (Himeidan et al., 2005a; Himeidan et al., 2005b). The predominant malaria parasite species is $\mathrm{P}$. falciparum, with P. vivax and P. malariae occasionally seen. Anopheles arabiensis is the sole malaria vector in the area (Himeidan et al., 2004b). The incidence of malaria varies considerably from year to year depending on the rainfall (Himedian et al., 2007). There is one teaching hospital, 40 dispensaries and one single-doctor hospital. Bed nets and malaria chemoprophylaxis are not used routinely in the area. 
Figure 1: The map of Sudan including the study area.

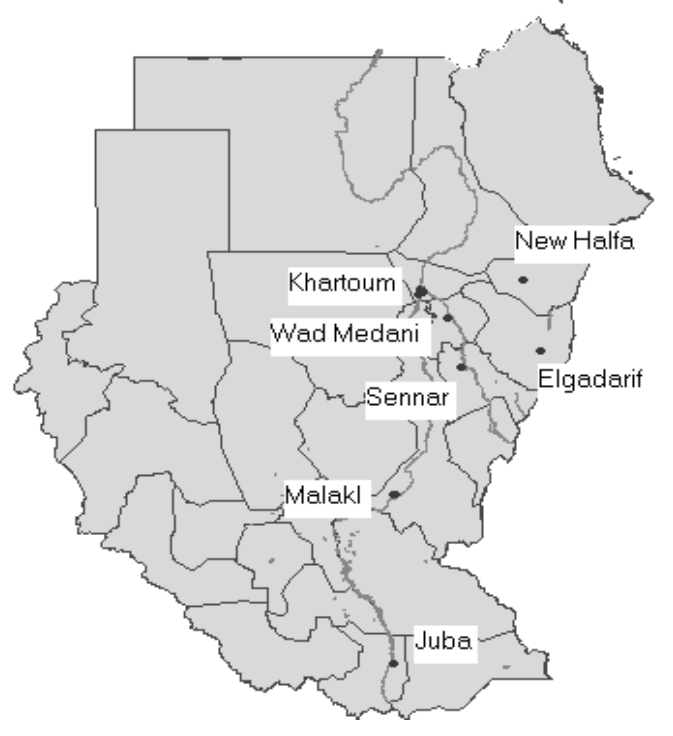




\section{REFERENCES}

Adam I, Ibashir M I. (2004). Maternal death due to severe pulmonary edema caused by falciparum malaria: Case report. East Mediterr Health J, 10: 685-688.

Adam I, Ali DM, Elbashir MI. (2004a). Manifestations of falciparum malaria among pregnant of Eastern Sudan. Saudi Med J, 25: 947-951

Adam I, Mirghani OM, Saed OK, Ahmed SM, Mohamadani AA, Ahmed HM, Mackenzie CD, Homeida MM, Elbashir MI. (2004b). Quinine therapy in severe Plasmodium falciparum malaria during pregnancy in Sudan. East Mediterr Health J, 10: 159-166.

Adam I, Khamis AH, Elbashir MI. (2005a). Prevalence and risk factors for malaria in pregnant women of eastern Sudan. Malar J, 4: 8.

Adam I, Khamis AH, Elbashir MI. (2005b). Prevalence and risk factors for anaemia in pregnant women of eastern Sudan. Trans R Soc Trop Med Hyg, 90: 739-743.

Beeson JG, Reeder JC, Rogerson SJ, Brown GV. (2001). Parasite adhesion and immune evasion in placental malaria. Trends Parasitol, 17:331.

Brabin BJ. (1983). Analysis of malaria in pregnancy in Africa. Bull World Health Organ, 611: 10051016.

Cot M, Deloron P. (2003). Malaria during pregnancy: consequences and interventional perspectives. Med Trop, 63: 369-380.

Dafallah SE, EL-Agib FH, Bushra GO. (2003). Maternal mortality in a teaching hospital in Sudan. Saudi Med J, 24: 369-373.

Fried M, Ouffy PE. (1998). Maternal malaria and parasite adhesion. J Mol Med, 76: 162-171.

Himiedan YE, Elbashir MI, Adam I. (2004a). Attractiveness of pregnant Sudanese women to malarial vector-Anopheles arabiansis. Ann Trop Med Parasitol, 98: 631-633.

Himeidan Y, El-Rayah E, Adam I. (2004b). Anopheles arabiensis: and insecticide resistance status in an irrigated area of eastern Sudan. East Mediterr Health J, 10: 166-175.

Himeidan YE, Elbashir MI, ELRayah E, Adam I. (2005a). Epidemiology of malaria in an irrigated area in the eastern Sudan. East Mediterr Health J, 11: 499-504.

Himeidan YE, Malik EM, Adam I. (2005b). Epidemiology and seasonal pattern of malaria in an irrigated area of eastern Sudan. Am J Infect Dis, 1: 75-78.

Himeidan YE, Hamid E, Rayah E, Elbashir MI, Adam I. (2007). Climatic variables and transmission of malaria: A 17-years data analysis in New Halfa Area in the Eastern Sudan. East Mediterr Health J, 13: 17-24.

Malik EM, Khalafalla OM. (2004). Malaria in Sudan: past, present and the future. Gezira J Heal Scien 1: (suppl) 47-51.

McGregor I A. (1984). Epidemiology, malaria and pregnancy. Am J Trop Med Hyg, 33: 517.

Menendez C, Ordi J, Ismail MR, Ventura PJ, Aponte JJ, Kahigwa E, Font F, Alonso PL, Ordi J. (2001). Placental malaria is associated with cell-mediated inflammatory responses with selective absence of natural killer cells. J Infect Dis, 183: 1100-1107.

Rasheed FN, Bulmer J, De Francisco NA, Jawla MF, Jakobsen PH, Jepson A, GreenWood BM. (1995). Relationships between maternal malaria and malarial immune responses in mothers and neonates. Parasite Immunology, 17: 1.

Steketee RW, Nahlen BL, Parise MF, Menendez C. ( 2001). The burden of malaria in pregnancy in malaria-endemic areas. Am J Trop Med Hyg, 64 (Suppl): 28-35.

Taha ET, Ronald HG, Abdullah A M. (1993). Malaria and low birth weight in central Sudan. Am J Epidemiol, 138: 315-325.

Tian LP, Nelson EA, Senok AC, Yu LM, Oppenheimer SJ, Li K. (1998). Red cell age and susceptibility to malaria during pregnancy. Act Obstet Gynecol Scand, 77: 717-721. 

Chapter 2

Plasmodium falciparum infection during pregnancy in an unstable transmission area in eastern Sudan

Published as: ElGhazali G, Adam I, Hamad AA, Elbashir M I. (2003). Malaria and pregnancy in an area of unstable transmission in eastern Sudan. East Mediterr Health J, 9: 571-580. 


\section{ABSTRACT}

\section{Background}

While the epidemiology of malaria during pregnancy has been extensively studied in highly endemic areas, very little data are available from areas with seasonal and unstable malaria transmission.

\section{Aims}

The study was conducted to investigate the susceptibility of pregnant women to P. falciparum malaria in comparison to non- pregnant women controls.

\section{Methods}

A one-year prospective community-based study of malaria during pregnancy was conducted in an area of unstable malaria transmission in eastern Sudan. At a village antenatal clinic, 89 nonpregnant controls and 86 pregnant women were enrolled and followed every 2 weeks until 6 weeks after delivery.

\section{Results}

The incidence of P. falciparum infection was significantly higher among pregnant than control women $(17.4 \%$ versus $5.6 \%)$ with no difference between primigravidae and multigravidae $(22.2 \%$ versus $15.2 \%$ ). There was a significant difference in the mean (SD) haemoglobin concentration between infected and uninfected mothers, $9.1(1.3)$ versus $9.5(0.6) \mathrm{g} / \mathrm{dL}, \mathrm{P}=0.001$. The mean (SD) birth weight of their babies was significantly lower in women infected with malaria, $2.72(0.26)$ versus $2.95(0.05) \mathrm{kg}$ ) despite prompt case management of infected women.

\section{Conclusion}

Thus in this area, pregnant women were found to be more susceptible to malaria than their nonpregnant ones. Malaria had adverse effects on pregnant women. Further studies are needed. 


\section{BACKGROUND}

In Africa each year around 24 million women become pregnant in malaria-endemic areas. Pregnancy increases susceptibility to malaria and pregnant women are more likely to develop clinical attacks of malaria and serious complications than non-pregnant women of the same age. The increased susceptibility of pregnant women to malaria is thought to be, in part, the result of a certain degree of immune suppression during pregnancy required for retention of the fetal allograft (Vleugels et al., 1987; Fievet et al., 1997).

The increased risk of malaria in pregnant women is associated with serious adverse effects in pregnancy, leading to miscarriage, preterm labour (Menon, 1976), intrauterine growth restriction (Brabin, 1991), intrauterine fetal death and low birth weight (McGregor, 1984). In addition to the effect of malaria on the fetus, malaria causes maternal anaemia, which contributes significantly to maternal morbidity and may be a risk factor for maternal death by increasing the case fatality rate in postpartum haemorrhage (Brabin and Piper, 1990). Malaria infection in the mother is also a risk factor for perinatal mortality and morbidity by reducing the baby's birth weight (Brabin, 1991).

There are some distinctive features of the epidemiology of malaria during pregnancy that are important in terms of raising relevant research questions about the basic immunological processes, as well as in deciding the control strategies to be applied. First, the susceptibility to malaria infection and severity of clinical manifestations of malaria are determined by the level of prepregnancy immunity, which largely depends on the intensity and stability of malaria transmission (McGregor et al., 1983). Secondly, an important epidemiological aspect is the effect of parity of the pregnant woman on susceptibility to and severity of malaria infection.

In areas that are highly endemic for P. falciparum infection, adult women have acquired substantial protective immunity to malaria through repeated prior infections (McGregor et al., 1983). Although the prevalence and density of $P$. falciparum parasites are higher in pregnant women than in non-pregnant women, most infections remain asymptomatic (Greenwood et al., 1988; Greenwood et al., 1994; Menendez, 1995), with little clinical consequences at least among multigravidae. The only clearly established beneficial effects of malaria chemoprophylaxis during pregnancy are to reduce maternal anaemia and increase the baby's birth weight in primigravidae (Garner and Brabin, 1994). Primigravidae in particular are an exception and suffer deleterious effects of malaria (particularly during the second trimester) whereas complications are less frequent in multigravidae women, indicating that the protective immunity in pregnancy is a function of parity (Brabin, 1983). The reason for this is unclear; immune suppression is probably more marked in primigravidae but it is also possible that protective immunity may be acquired in the reproductive tract through malaria infection during the first pregnancy, reducing susceptibility in later pregnancies (Greenwood et al., 1994).

In areas where malaria transmission is seasonal and unstable, both the mother and her fetus can suffer the most severe consequences of the infection (Menendez, 1995). In these areas, it is believed the degree of acquired immunity of the women prior to pregnancy is likely to be low or poorly developed and the epidemiological profile and clinical pattern of disease are different from that seen in highly endemic areas (Snow et al., 1977). While the epidemiology of malaria during pregnancy has been extensively studied in highly endemic areas, very little data are available from areas with seasonal and unstable malaria (Nosten et al., 1991). The present study was conducted to investigate the pattern of malaria morbidity during pregnancy among women living in unstable malaria transmission in eastern Sudan (Himeidan et al., 2005a; Himeidan et al., 2005b).

\section{METHODS}

\section{Study area}

The study was performed in Elhara Eloula, a village in the New Halfa area in the eastern Sudan. The population in the last census in 2001 was 1841. The New Halfa town was constructed in 1964 to settle the inhabitants of old Halfa in the northern border of Sudan who were displaced after 
construction of the High Dam on the Nile in Egypt. The area is characterized by unstable malaria transmission with peak transmission following the rainy season (September to January). The predominant malaria parasite species is P. falciparum, with P. vivax and P. malariae occasionally seen. Anopheles arabiensis is the sole malaria vector in the area (Himeidan et al., 2004). The incidence of malaria varies considerably from year to year depending on the rainfall (Himeidan et al., 2007). Bed nets and malaria chemoprophylaxis are not used routinely in the area.

\section{Study design and population}

This was a prospective community-based study that was timed to begin before the malaria transmission season (late June) and continue for one year. An antenatal clinic was initiated in the health centre in the village. Our aim was to enroll and follow-up all pregnant women in the village, an average of 6-10 women per day. All pregnant women were encouraged to attend the antenatal clinic. Free medical care (including free medication) was provided, so it was unlikely that the women sought medical advice elsewhere. For each pregnant woman the nearest non-pregnant woman neighbour, matched for age and socioeconomic status, was asked to participate in the study as part of a control group.

\section{Data collection}

The clinical and obstetric history of the women was recorded in detail, including last menstrual period, gravidity, parity and history of miscarriage or preterm labour.

Obstetric and physical examinations were carried out on pregnant women (blood pressure, pallor, and fundal level). The pregnancy and its duration were calculated from the last menstrual period and confirmed by ultrasound, which also used to exclude pregnancy in the controls. After enrolment, pregnant women were requested to present to the antenatal clinic once every 2 weeks until 6 weeks after delivery. Control women also attended every 2 weeks. Our team (medical officer and a microscope technician) was available daily to take care of those presenting with complaints. Initially and at every visit women were asked specifically about symptoms suggestive of malaria (fever, headache, sweating, joint pain and vomiting). Parasitological and detailed medical examinations were carried out in cases presenting to the medical staff complaining of fever or giving a recent history of fever (within the past 3 days). Due to the high rate of chloroquine resistance in the area (Adam et al., 2004), confirmed P. falciparum infections were treated with quinine $10 \mathrm{mg} / \mathrm{kg}$ body weight 3 times/day for 7 days.

At every visit, pregnant women were supplied with ferrous sulfate $(200 \mathrm{mg} / 1$ tablet per day) and folic acid ( $0.5 \mathrm{mg} / 1$ tablet per day). Deliveries were conducted by trained midwifes and the birth weight was recorded (to the near $50 \mathrm{~g}$ ) within 24 hours of delivery. High-risk patients were advised to deliver in New Halfa hospital under the supervision of an obstetrician.

\section{Parasitology and clinical tests}

Blood was taken by finger prick from subjects complaining of fever and thick and thin blood films were prepared and stained with Giemsa ( $\mathrm{pH} 7.0$, diluted with phosphate buffered saline). The thick blood films were used to detect the malaria parasite and the thin films for defining the parasite species. For parasite detection, 100 fields were examined irrespective of the parasites encountered. The parasitological data were crosschecked by another technician, blind to the results and verified by the supervisor if there was any controversy. The number of asexual parasites per 200 leukocytes was counted and parasite densities (asexual parasites/ $\mu \mathrm{L}$ ) were calculated assuming a normal value of 6000 leukocytes/ $\mu \mathrm{L}$ blood. The haemoglobin concentration was measured using a modified Sahli method (Barduagni, 2003).

A malaria episode was defined by a positive parasitology result, regardless of symptoms. An episode of symptomatic malaria was fever (oral temperature $>37.5^{\circ} \mathrm{C}$ ) or a history of fever together with parasitaemia. Anaemia was defined as a haemoglobin concentration $<11 \mathrm{~g} / \mathrm{dL}$ and severe anaemia as $<7 \mathrm{~g} / \mathrm{dL}$. Miscarriage was defined as expulsion of a dead fetus before 28 weeks gestation. Premature labour was labour before completion of 37 weeks of gestation. Perinatal death was death from 28 weeks in utero until the age of 1 week. Low birth weight was defined as birth weight less than $2500 \mathrm{~kg}$. 


\section{Statistical analysis}

Data were entered into a computer database and were analyzed using the statistical program SPSS for Windows, version 11.5. Student's t-test, chi-squared and Fisher exact test were used as appropriate. $\mathrm{P}<0.05$ was regarded as significant.

\section{Ethical considerations}

Women consented to participate in the study after being given adequate information on the objectives and benefits of the project. The study was monitored and supervised by qualified medical personnel whose first responsibility was the welfare of the patients enrolled in the study. At all times, proper patient management took priority over continuation of the study. The study was carried out following WHO Guidelines for good clinical practice (WHO, 1995). To maintain the privacy of women participating in the study, patient data were treated as confidential and each woman was coded in the computer database.

\section{RESULTS}

Out of 209 women enrolled, 175 completed the study ( 86 pregnant and 89 control women) during 2 dry seasons and one wet season (June 2001 to May 2002). The remaining 34 were excluded because of their absence from the village for more than 4 consecutive visits or they delivered before the rainy season. As shown in Table 1, no significant differences were seen between the 2 groups of women (pregnant and non-pregnant controls) in basic characteristics. None of the women in the control group became pregnant during the study period. The mean gestational age (SD) of pregnant women at the time of enrolment was 22.2 (9.1) weeks.

\section{Malaria during pregnancy}

All infections occurred during the transmission season following the rainy season. All infections were due to P. falciparum and no P. vivax or P. malariae was detected. Fifteen (17.4\%) out of 86 pregnant women became infected with P. falciparum versus $5(5.6 \%)$ out of 89 in the control group, $\mathrm{P}=0.014$. Table 1 .

Malaria infections were detected in $6(22.2 \%)$ out of the 27 primigravidae, one $(8.3 \%)$ of 12 secundigravidae and $8(17.0 \%)$ of 47 of multigravidae. $P=0.4$. Women were infected at mean (SD) $29.9(0.8)$ weeks gestational age. Eleven $(73.3 \%)$ of the infected 15 cases occurred in the third trimester of pregnancy, while only $4 / 15(26.7 \%)$ were in the second trimester and none in the first trimester. Most of the infections (66.6\%) were symptomatic (e.g. fever, headache, joint pain) at presentation.

Table 1 comparison of variable between pregnant and control (non-pregnant) women*

\begin{tabular}{llllll}
\hline Variable & \multicolumn{2}{l}{$\begin{array}{l}\text { Pregnant women } \\
(\mathrm{n}=86)\end{array}$} & \multicolumn{2}{l}{$\begin{array}{l}\text { Control women } \\
(\mathrm{n}=89)\end{array}$} & $\mathrm{P}$ \\
\hline Age, years & 25.4 & $(5.9)$ & 24.4 & $(4.9)$ & 0.2 \\
Parity & 2.1 & $(2.2)$ & 2.4 & $(2.9)$ & 0.4 \\
Weight, Kg & 58.5 & $(9.7)$ & 56.5 & $(8.7)$ & 0.08 \\
History of miscarriage & 27 & $(31)$ & 21 & $(34.7)$ & 0.2 \\
Antennal visits & 8.1 & $(3.4)$ & 8.9 & $(3.8)$ & 0.1 \\
Incidence of malaria & 15 & $(17.4)$ & 5 & $(5.6)$ & 0.01
\end{tabular}

* Data were shown as mean (SD) or $\mathrm{n}(\%)$ as applicable. 


\section{Malaria and haemoglobin levels}

Table 2 compares different variables among the infected $(n=15)$ and non-infected $(n=71)$ pregnant women. The mean (SD) haemoglobin levels at enrolment were not statistically different in pregnant patients who developed malaria infection compared with those who did not: 9.35 $(0.80) \mathrm{g} / \mathrm{dL}$ versus $9.32(1.10) \mathrm{g} / \mathrm{dL}(P=0.8)$. However, at term, the mean haemoglobin levels were significantly lower among those who developed malaria during pregnancy: 9.10 (1.30) $\mathrm{g} / \mathrm{dL}$ versus $9.50(0.60) \mathrm{g} / \mathrm{dL}(P=0.001$ (Table 2$)$. One of the infected pregnant women presented with severe anaemia (haemoglobin level $4.5 \mathrm{~g} / \mathrm{dL}$ ).

Table 2 comparison of the mean (SD) of the different variables between women who developed malaria and those who did not.

\begin{tabular}{llllll}
\hline Variable & \multicolumn{2}{l}{$\begin{array}{l}\text { Infected women } \\
(\mathrm{N}=15)\end{array}$} & \multicolumn{2}{l}{$\begin{array}{l}\text { Non- infected women } \\
(\mathrm{N}=71)\end{array}$} & $\mathrm{P}$ \\
\hline Age, years & 24.5 & $(6.2)$ & 26.7 & $(6.2)$ & 0.2 \\
Haemoglobin at enrollment, $\mathrm{g} / \mathrm{dl}$ & 9.35 & $(0.8)$ & 9.32 & $(1.1)$ & 0.8 \\
Haemoglobin at term, g/dl & 9.1 & $(1.3)$ & 9.5 & $(0.6)$ & 0.001 \\
Birth weight, $\mathrm{Kg}$ & 2.72 & $(0.26)$ & 2.95 & $(0.05)$ & 0.001 \\
\hline
\end{tabular}

\section{Malaria and birth weight}

The mean (SD) birth weight of babies born to malaria-infected women ( $\mathrm{n}=13,2$ cases not determined) was significantly lower compared with those born to non-infected women: $2.72(0.26)$ $\mathrm{kg}$ versus $2.95(0.05) \mathrm{kg}, \mathrm{P}=0.04$, Table 2 . The mean (SD) birth weight of babies born to primigravidae was not statistically different from those born to multiparae, $2.73(0.56) \mathrm{kg}$ versus $2.97(0.53) \mathrm{kg}, \mathrm{P}=0.7$.

\section{Pregnancy outcome}

One maternal death was reported as a complication of septicaemia following obstructed labour. Four perinatal deaths occurred, all in the non-infected group, and no clear reason was identified. One of the non-infected women aborted her fetus at 10 weeks gestational age. Four of the pregnant women (4/86) delivered prematurely $(2 / 15$ in the infected group and 2/71 in the noninfected group).

\section{Treatment response}

P. falciparum-infected patients (pregnant and controls) received prompt, adequate treatment according to the Sudanese national drug policy and response to treatment was assessed. All the infected women responded satisfactory to quinine therapy; all were symptom-free by day 3 and their blood films were negative on days 7, 14, 21 and 28.

\section{DISCUSSION}

This was a prospective study of $P$. falciparum malaria during pregnancy in an area of unstable malaria transmission in the eastern Sudan. The infection rate was significantly higher in the pregnant compared with the non-pregnant women. This finding was supported by data from areas where malaria is hyperendemic (McGregor, 1984). The incidence of infection in pregnant women during the study year was surprisingly lower than expected compared with the preceding years (Adam unpublished). This can be explained by two factors. First, the rainfall during the study period was low. The incidence of malaria in eastern Sudan varies considerably from year to year depending on the rainfall (Himedan et al., 2007). Secondly, for the first time, a vector control strategy was applied in the area and all houses in the province were sprayed with deltamethrin. 
In contrast to studies conducted in areas where malaria transmission is stable (McGregor, 1984; Shulman et al., 2001), this study showed that the infection rate was not different between primigravidae and multigravidae. Studies from an area with perennial malaria transmission in Africa showed a higher prevalence of infection in all pregnant women but highest in primigravidae (McGregor, 1984; (Shulman et al., 2001), with both gravidity influencing susceptibility to malaria infection (Mutabingwa et al., 1993; Cot et al., 1995; Bouvier et al,. 1997). In addition, there was no significant difference in age between infected and non-infected pregnant women. Giha et al. observed that in eastern Sudan the incidence of malaria was significantly higher in individuals aged 5 to 19 years compared with older age groups (> 20 years); however, pregnant women were not included in that study (Giha, 2000). Bouyou-Akotet et al. (2003) showed that primigravidae and young pregnant women are most susceptible to malaria infection.

In this study, there was strong tendency for a lower mean haemoglobin concentration near delivery in those pregnant women who developed malaria. Data from an area of unstable malaria transmission in Thailand (Nosten et al., 1991) showed significantly lower haemoglobin concentrations in pregnant women who became infected despite prompt diagnosis and antimalarial treatment, and the study was further confirmed by another study from areas of unstable malaria transmission in Ethiopia (Newman et al., 2003).

The mean birth weight of babies in our study was significantly lower in the mothers who became infected during pregnancy. The finding is consistent with the observation by Nosten et al., where the birth weight was significantly lower in the pregnant women who developed malaria despite early diagnosis and treatment (Nosten et al., 1991). Studies from areas of stable malaria transmission (Mutabingwa et al., 1994), including areas of Ethiopia (Newman et al., 2003), also found a significant association between malaria and reduced birth weights. However, in areas of unstable malaria in Ethiopia (Newman et al., 2003), Newman found no significant association between malaria and decreased birth weight and this contrasts with our own observation and Nosten's (Nosten et al., 1991). Malaria was a known cause of low birth weight in the central Sudan, as well as in the other African countries (Taha et al., 1993; Guyatt and Snow, 2001).

In our study the reduction in the birth weight of babies born to pregnant women who became infected occurred in spite of active diagnosis and effective therapy with the standard quinine regime. Low birth weight has been closely linked with 'placental' rather than 'peripheral' parasitaemia (Galbraith et al., 1989). The parasite sequestration in the placenta is considered to be the main pathological mechanism (Shulman and Dorman, 2003) and the placenta is often heavily infected with P. falciparum (Diagne et al., 1997). Placental infection leads to thickening of the syncytiotrophoblasts, abnormal utero/placental blood flow and placental insufficiency. As low birth weight is the leading cause of infant mortality (Menendez et al., 2000), prevention of this should be a major goal.

In areas of moderate or high malaria transmission, including large parts of Africa, malaria in pregnancy is a common cause of severe maternal anaemia and reduced birth weight of babies, these complications being more common in primigravidae than multigravidae (Fried and Duffy, 1996). In our study, there was no significant difference between the birth weight of babies born to primigravidae or multigravidae.

Pregnancy is known to induce a state of immune suppression. Timing of peak suppression and increased susceptibility to infection is of importance for timing of possible intervention to reduce severe adverse effects of malaria on both the mother and the baby. In our study, over $70 \%$ of the infections were in the third trimester and no infections were reported during the first trimester. This may be because pregnant women presented to the antenatal care clinic for the first time during the second trimester, as the mean gestational at enrolment was 22 weeks. A peak incidence rate of malaria attacks during the second trimester was observed in areas with perennial transmission (Luxemburger et al., 2001). In this study, all infections occurred during the narrow transmission season following the rainy season. Almost two-thirds of infections were symptomatic which may suggest that the level of immunity is low and inadequate. This is in contrast to data from 
areas where malaria is stable and hyper-endemic, malaria is still frequently asymptomatic, and may go unsuspected and undetectable, but may be associated with placental parasitization (Shulman et al., 2001). In spite of the fact that most of the infections were detected actively after development of clinical malaria, no mortality was associated with malaria.

Thus, in these areas, the prevention of low birth weight could be possible by measurements such as reduction of exposure to the vector, and effective preventive treatment with sulphadoxine/pyrimethamine provided in 2 single doses during and at the end of the transmission season to all pregnant women (during the second and third trimester) irrespective of parity. In addition, routine hospital data such as birth weight and number of malaria cases can provide information on the level of malaria transmission useful for the health services to target appropriate malaria interventions and allocate resources to control outbreaks of malaria epidemics.

\section{ACKNOWLEDGEMENTS}

We wish to thank all pregnant women and their families who participated in the study and we are very grateful to the local health authorities in Kassala State. Thanks are also extended to $\mathrm{Mr}$ Abdalla Ahmed Hufazalla and Mr Tarig Elfaki for their excellent technical assistance. This investigation received technical and financial support from the joint WHO Eastern Mediterranean Region (EMRO), Division of Communicable Diseases (DCD) and the WHO Special Programme for Research and Training in Tropical Diseases (TDR): the EMRO/DCD/TDR Small Grants Scheme for Operational Research in Tropical and Communicable Diseases. 


\section{REFERENCES}

Adam I, Osman ME, ElGhazali G, Ahmed GI, Gustafson LL, Elbashir M I. (2004). Efficacies of chloroquine, sulphadoxine-pyrimethamine and quinine for the treatment of uncomplicated Plasmodium falciparum malaria in Eastern Sudan. Ann Trop Med Parasitol, 98: 661-666.

Brabin BJ. (1983). Analysis of malaria in pregnancy in Africa. Bull World Health Organ, 611: 10051016.

Brabin B. (1991). The risks and severity of malaria in pregnant women. Applied filed research in malaria, Report No.1Geneva, World Health Organization.

Brabin B, Piper C. (1997). Anaemia and malaria attributable low birth weight in two populations in Papua New Guinea. Ann Hum Biol, 24: 547-555.

Brabin B. (1991). An assessment of low birthweight risk in primiparae as an indicator of malaria control in pregnancy. Inter J Epidemiol, 20: 276-283.

Barduagni P, Ahmed AS, Curtale F, Raafat M, Soliman L. (2003). Performance of Sahli and colour scale methods in diagnosing anaemia among school children in low prevalence areas. Trop Med Inter Heal, 8: 615-618.

Bouyou-Akotet MK, lonete-Collard DE, Mabika-Manfoumbi M, Kendjo E, Matsiegui P-B, Mavoungou E, Kombila M. (2003). Prevalence of Plasmodium falciparum infection in pregnant women in Gabon. Malar J, 2: 18.

Bouvier P, Breslow N, Doumbo O, Robert CF, Picquet M, Mauris A, Dolo A, Dembele HK, Delley V, Rougemont A. (1997). Seasonality, malaria, and impact of prophylaxis in a West African village. II. Effect on birthweight. Am J Trop Med Hyg, 56:384-389.

Cot M, Le Hesran JY, Miailhes P, Esveld M, Etya'ale D, Breart G. (1995). Increase of birth weight following chloroquine chemoprophylaxis during the first pregnancy: results of a randomized trial in Cameroon. Am J Trop Med Hyg, 53: 581-585.

Diagne N, Rogier C, Cisse B, Trape JF. (1997). Incidence of clinical malaria in pregnant women exposed to intense perennial transmission. Trans R Soc Trop Med Hyg, 91:166-170.

Fievet N, Cot M, Ringwald P, Bickii J, Dubois B, Le Hesran JY, Migot F, Deloron P. (1997). Immune response to Plasmodium falciparum antigens in Cameroonian primigravidae: evolution after delivery and during second pregnancy. Clin Exper Immunol, 107: 462-467.

Fried M, Duffy PE. (1996). Adherence of Plasmoduim falciparum to chondrotin sulphate $A$ in human placenta. Science, 272:1502-1504.

Galbraith RM. (1989). The human materno-foetal relationship in malaria: I. Identification of pigment and parasites in the placenta. Trans R Soc Trop Med Hyg, 74:52-60.

Garner P, Brabin B. (1994). A review of randomised controlled trials of routine antimalarial drug prophylaxis during pregnancy in endemic malarious areas. Bull World Health Organ, 72: 8999.

Giha HA, Rosthoj S, Dodoo D, Hviid L, Satti GM, Scheike T, Arnot DE, Theander TG. (2000). The epidemiology of febrile malaria episodes in an area of unstable and seasonal transmission. Trans R Soc Trop Med Hyg, 94: 645-651.

Greenwood BM, Greenwood AM, Snow RW, Byass P, Bennett S, Hatib-N'Jie AB. (1989). The effects of malaria chemoprophylaxis given by traditional birth attendants on the course and outcome of pregnancy. Trans R Soc Trop Med Hyg, 83:589-594.

Greenwood AM, Menendez C, Todd J, Greenwood BM. (1994). The distribution of birth weights in Gambian women who received malaria chemoprophylaxis during their first pregnancy and in control women. Trans R Soc Trop Med Hyg, 88:311-312.

Guyatt $\mathrm{HI}$, Snow RW. (2001). Malaria in pregnancy as indirect cause of infant mortality in subSaharan Africa. Trans R Soc Trop Med Hyg, 95:569-576.

Himeidan YE, Elbashir MI, ELRayah E, Adam I. (2005a). Epidemiology of malaria in an irrigated area in the eastern Sudan. East Mediterr Health J, 11: 499-504. 
Himeidan YE, Malik EM, Adam I. (2005b). Epidemiology and seasonal pattern of malaria in an irrigated area of eastern Sudan. Am J Infect Dis, 1: 75-78.

Himeidan YE, Hamid E, Rayah E, Elbashir MI, Adam I. (2007). Climatic variables and transmission of malaria: A 17-years data analysis in New Halfa Area in the Eastern Sudan. East Mediterr Health J, 13: 17-24.

Luxemburger C, Ricci F, Nosten F, Raimond D, Bathet S, White NJ. (1997). The epidemiology of severe malaria in an area of unstable and low transmission in Thailand. Trans R Soc Trop Med Hyg, 91: 256-262.

McGregor IA, Wilson ME, Billewicz WZ. (1983). Malaria infection of the placenta in the Gambia, West Africa; its incidence and relationship to stillbirth, birthweight and placental weight. Trans R Soc Trop Med Hyg, 77: 232-244.

McGregor IA. (1984). Epidemiology, malaria and pregnancy. Am J Trop Med Hyg, 33: 517-525.

Menendez C. (1995). Malaria during pregnancy: A priority area of malaria research and control. Parasitol Today, 11: 178-183.

Menendez C, Ordi J, Ismail MR, Ventura PJ, Aponte JJ, Kahigwa E, Font F, Alonso PL. (2000). The impact of placental malaria on gestational age and birth weight. J infect dis, 181:1740-1745.

Newman RD, Hailemariam A, Jimma D, Degefie A, Kebede D, Rietveld AC, Nahlen BL, Barnwell JW, Steketee RW, Parise ME. (2003). Burden of malaria during pregnancy in areas of stable and unstable transmission in Ethiopia during a nonepidemic year. J Infect Dis, 187: 1765-1772.

Nosten F, Ter Kuile FO, Maelankirri L, Decludt B, White NJ. (1991). Malaria during pregnancy in an area of unstable endemicity. Trans R Soc Trop Med Hyg, 85: 424-429.

Menon R. (1972). Pregnancy and malaria. Medical Journal of Malaysia, 27:115-119.

Mutabingwa TK, Malle LN, Verhave JP, Eling WM, Meuwissen JH, de Geus A. (1993). Malaria chemo-suppression during pregnancy. IV. Its effects on the newborn's passive malaria immunity. Trop Geog Med, 45:150-156.

Mutabingwa TK, de Geus A, Meuwissen JH, Malle LN. (1994). Malaria chemosup-pression during pregnancy. VI. Some epidemiological aspects of malaria in infants. Trop Geog Med, 46:1-7.

Shulman CE, Marshall T, Dorman EK, Bulmer JN, Cutts F, Peshu N, Marsh K. (2001). Malaria in pregnancy: adverse effects on haemoglobin levels and birthweight in primigravidae and multigravidae. Trop Med Inter Heal, 6: 770-778.

Shulman CE, Dorman EK. (2003). Importance and prevention of malaria in pregnancy. Trans R Soc Trop Med Hyg, 97:30-35.

Snow RW. (1977). Relation between severe malaria mortality in children and level of Plasmodium falciparum transmission in Africa. Lancet, 349:1650-1654.

Taha ET, Ronald HG, Abdullah A M. (1993). Malaria and low birth weight in central Sudan. Am J Epidemiol, 138: 315-325.

Vleugels MP, Eling WM, Rolland R, de Graaf R. (1987). Cortisol and loss of malaria immunity in human pregnancy. Br J Obstet Gynaecol, 94: 758-764.

WHO, Guidelines for good clinical practice (GCP) for trials on pharmaceutical products. Geneva, World Health Organization, 1995 (WHO Technical Report Series, No. 850). 


\section{Chapter 3}

\section{Prevalence and risk factors for Plasmodium falciparum malaria in pregnant women of eastern Sudan}

Published as: Adam I, Khamis AH, Elbashir MI. (2005). Prevalence and risk factors for malaria in pregnant women of eastern Sudan. Malar J, 4: 8. 


\section{ABSTRACT}

\section{Background}

The presentation of malaria during pregnancy varies according to the level of transmission in the area. While much data available form areas of stable malaria transmission, few data are available from areas characterized by unstable malaria transmission.

\section{Aim}

The study aimed to demonstrate the prevalence and risk factors for malaria (age, parity and gestational age) among pregnant women of eastern Sudan, which is characterized by unstable malaria transmission.

\section{Methods}

A cross sectional study was conducted in the antenatal clinic of New Halfa Teaching Hospital, eastern Sudan, during October 2003-April 2004.

\section{Results}

A total 102 (13.7\%) of 744 women had P. falciparum malaria, 18 (17.6\%) of these were severe cases (jaundice and severe anaemia). Univariate and multivariate analysis showed that, age and parity were not associated with malaria. Women who attended the antenatal clinic in the third trimester were at highest risk for malaria $(O R=1.58,95 \% \mathrm{Cl}=1.02-2.4 ; \mathrm{P}<0.05)$.

Women with malaria had significantly lower mean haemoglobin $(9.4 \mathrm{~g} / \mathrm{dl}, 95 \% \mathrm{Cl} 9.1-9.7$ versus 10.7, $\mathrm{Cl} 10.6-10.8, \mathrm{P}<0.05)$. A significantly lower haemoglobin was observed in those with severe $\mathrm{P}$. falciparum malaria compared to those with non-severe form $(8.3 \mathrm{~g} / \mathrm{dl}, 95 \% \mathrm{Cl} 7.6-9.1$ versus 9.4 , 95\% Cl 9.1-9.7, $\mathrm{P}=<0.05)$.

\section{Conclusion}

The results suggest that $\mathrm{P}$. falciparum malaria is common in pregnant women attending antenatal care and that anaemia is an important complication. Preventive measures (chemoprophylaxis and insecticide-treated bednets) may be beneficial in this area for all women irrespective of age or parity. 


\section{BACKGROUND}

Pregnant women are more susceptible to malaria, which causes serious adverse effects including miscarriage, low birth weight and maternal anaemia (Brabin, 1983; McGregor, 1984; Nosten et al., 1991; Menendez, 1995; Newman et al., 2003). It is the leading cause maternal mortality in Sudan (Dafallah et al., 2003; Adam and Elbashir, 2004).

The presentation of malaria during pregnancy varies according to the pre-existing immunity of the mother. Women living in areas of unstable malaria transmission have little immunity to malaria which can cause severe syndromes, such as cerebral malaria and pulmonary oedema (Adam et al., 2004). In contrast, those who live in areas of stable malaria transmission enjoy greater immunity and experience fewer symptoms during episodes of malaria, although they commonly develop severe anaemia as consequence of the infection (Brabin, 1983; McGregor, 1984; Nosten et al., 1991; Menendez, 1995; Okoko et al., 2003; Shulman and Dorman, 2003).

Understanding the epidemiology of malaria during pregnancy provides important insight into relevant immunological processes and facilitates decision on control strategies. Although there are extensive studies in highly endemic African countries (Brabin, 1983; McGregor, 1984; Rogerson et al., 2000; Bouyou-Akotet et al., 2003; Dicko et al., 2003; Newman et al., 2003), there is little published data available for Sudan, an African country where P. falciparum malaria transmission is unstable in the eastern region (Himiedan et al., 2005). This study was conducted to investigate the prevalence and associated risk factors for P. falciparum malaria in pregnant women from eastern Sudan.

\section{PATIENTS AND METHODS}

\section{Data collection}

Pregnant women attending antenatal clinic (booking visit) of the New Halfa Teaching Hospital, eastern Sudan, during the period October 2003-April 2004 were approached to participate in the study. After consent, questionnaires were administered requesting demographic informations on age, parity, gestational age and history of maternal illness. Gestational age was calculated from the last menstrual period and confirmed by ultrasound, when clinically indicated. Physical examination was completed to identify signs of severe malaria (WHO, 2000) and also obstetrical examination (blood pressure, pallor, fundal level and foetal heart sound).

\section{Laboratory methods}

Thick and thin blood films were prepared from capillary blood, stained with Giemsa and 100 oil immersion fields were examined. Parasite density was determined by counting parasites and 200 leucocytes, assuming each woman has 6,000 leucocytes/ $\mu$ l. All the slides were double-checked blindly.

The haemoglobin concentration was estimated by the haematic acid method (Sahli , 1984) in the first two months and, subsequently, using Haemocure haemoglobinometer (HemCue $A B$, Angelhom, Sweden). Ferrous sulfate $(200 \mathrm{mg} /$ day $)$ and folic acid tablets (0.25 mg/day) were supplied.

\section{Ethical clearance}

The study received ethical clearance from the Research Board of the Faculty of Medicine, University of Khartoum.

\section{Statistical analysis}

Data were entered in a computer using SPSS for windows. Comparisons between means and percentages were done by Students' t-test, ANOVA, X2 and Fisher's exact tests as appropriate. P < 0.05 was regarded as significant. Multivariate logistic regression was performed with malaria as the dependent variable, using age, parity and gestation as independent variables. These variables were 
categorized and used as follows: median age, < 25 years versus $>25$ years); gravidae as primigravidae, secundigravidae, multigravidae (3-5)or grandmultigravidae >5; gestation as first (< 14 weeks), second (14-28 weeks) and third (> 28 weeks) trimester.

\section{RESULTS}

\section{Malaria and pregnancy}

A total of 744 pregnant women attended the antenatal clinic of New Halfa Teaching Hospital during the study, $29.5 \%$ were primigravidae.

Table 1 summarizes patient characteristics for all sub-groups. 102 (13.7\%) of women were infected with P. falciparum, 18(17.6\%) of these were severe cases (jaundice and severe anaemia). Malaria prevalence and intensity (parasite count) were not significantly different amongst the different gravidity sub-groups $(P>0.05)$. The highest prevalence $(18.3 \%)$ occurred in grandmultigravidae and the highest intensity $(11,511$ parasites/ $\mu \mathrm{l})$ was observed in primigravidae, Table 1.

Mean (SD) age, 26.2 (5.7) versus 25.9 (5.3) years, $\mathrm{P}>0.05)$ and parity, 2.4 (2.4) versus 2.1 (2.1), P > 0.05) were not significantly different between infected and non-infected women. Two of 18 (11.1\%), 29 of $290(10 \%)$ and 71 of $436(16.3 \%)$ women were infected in the first, second and third trimester respectively $(P=0.05)$.

Table 1 characteristics of pregnant women in the study subjects *

\begin{tabular}{|c|c|c|c|c|c|c|c|c|c|c|c|}
\hline \multirow{2}{*}{$\begin{array}{l}\text { Characteristics } \\
\text { Age, years }\end{array}$} & \multicolumn{2}{|c|}{$\begin{array}{l}\text { Total } \\
(\mathrm{N}=744)\end{array}$} & \multicolumn{2}{|c|}{$\begin{array}{l}\text { Primi- } \\
\text { gravidae } \\
(\mathrm{N}=220)\end{array}$} & \multicolumn{2}{|c|}{$\begin{array}{l}\text { Secundi- } \\
\text { gravidae } \\
(\mathrm{N}=131)\end{array}$} & \multicolumn{2}{|c|}{$\begin{array}{l}\text { Multi- } \\
\text { gravidae } \\
(\mathrm{N}=322)\end{array}$} & \multicolumn{2}{|c|}{$\begin{array}{l}\text { Grand- } \\
\text { multigravidae } \\
(\mathrm{N}=71)\end{array}$} & \multirow{2}{*}{$\begin{array}{l}\text { PValue } \\
<0.001\end{array}$} \\
\hline & 26.6 & (9.9) & 21.2 & (2.9) & 25.7 & (2.3) & 28.2 & (3.8) & 34.9 & (3.2) & \\
\hline $\begin{array}{l}\text { Gestation, } \\
\text { weeks }\end{array}$ & 27.7 & (7.7) & 27.3 & (8.09) & 28.1 & (6.9) & 27.6 & (7.6) & 28.3 & $(28.3)$ & 0.18 \\
\hline $\begin{array}{l}\text { Haemoglobin } \\
(g / d l)\end{array}$ & 10.5 & (1.4) & 10.5 & (1.3) & 10.3 & (1.6) & 10.6 & (1.3) & 10.3 & (1.2) & 0.2 \\
\hline Malaria (total) & 102 & (13.7) & 32 & (14.5) & 14 & (10.7) & 43 & (13.4) & 13 & $(18.3)$ & 0.4 \\
\hline Non-severe & 84 & (11.3) & 28 & (12.7) & 9 & (6.9) & 34 & (10.6) & 13 & (18.3) & 0.08 \\
\hline Severe & 18 & (2.4) & 4 & (1.8) & 5 & (3.8) & 9 & (2.8) & 0 & & 0.3 \\
\hline $\begin{array}{l}\text { Parasite count } \\
\text { (parasites/ } / \mu \mathrm{l})\end{array}$ & 6.5 & (19.6) & 11.5 & (3.2) & 6.8 & (14.3) & 3.5 & (7.7) & 4.4 & (7.7) & 0.4 \\
\hline
\end{tabular}

*Data as mean (SD) or number (\%) as appropriate

\section{Factors associated with malaria infection}

Univariate and multivariate analysis indicated that, age and parity were not significantly associated with malaria infection. The third trimester was significantly associated with malaria infection $(O R=$ $1.58,95 \% \mathrm{Cl}=1.02-2.4 ; \mathrm{P}<0.05)$, Table 2 .

\section{Malaria and haemoglobin}

Mean haemoglobin was significantly lower in infected women $(9.4 \mathrm{~g} / \mathrm{dl}, 95 \% \mathrm{Cl}$ 9.1-9.7versus 10.7 , $\mathrm{Cl} 10.6-10.8, \mathrm{P}<0.05)$. A lower haemoglobin also occurred in women with severe malaria $(9.4 \mathrm{~g} / \mathrm{dl}$, $95 \% \mathrm{Cl}$ 9.1-9.7 versus $8.3,95 \% \mathrm{Cl} 7.6-9.1, \mathrm{P}<0.05$. 
Table 2 risk factor analysis

\begin{tabular}{|c|c|c|c|c|c|c|}
\hline \multirow[b]{2}{*}{ Variable } & \multicolumn{3}{|c|}{ Univariate } & \multicolumn{3}{|c|}{ Multivariate } \\
\hline & OR & $95 \% \mathrm{Cl}$ & $P$ & OR & $95 \% \mathrm{Cl}$ & $P$ \\
\hline Age $\leq 25$ years & 1.03 & $0.68-1.5$ & 0.40 & 0.90 & $0.52-1.6$ & 0.74 \\
\hline \multicolumn{7}{|l|}{ Parity } \\
\hline Primigravidae & 1.10 & $0.70-1.7$ & 0.60 & 0.76 & $0.32-1.8$ & 0.55 \\
\hline Secundigravidae & 0.72 & $0.39-1.3$ & 0.20 & 0.50 & $0.21-1.4$ & 0.22 \\
\hline Multigravidae & 0.96 & $0.62-1.4$ & 0.80 & 0.74 & $0.37-1.4$ & 0.41 \\
\hline Grandmultigravidae & 1.40 & $0.77-2.7$ & 0.20 & 3.20 & $0.27-46.2$ & 0.30 \\
\hline \multicolumn{7}{|l|}{ Gestational age } \\
\hline First trimester & 0.61 & $0.27-1.3$ & 0.15 & 0.51 & $0.22-1.1$ & 0.11 \\
\hline Second Trimester & 0.71 & $0.45-1.3$ & 0.09 & 0.67 & $0.41-1.08$ & 0.10 \\
\hline Third trimester & 1.50 & $1.02-2.4$ & 0.02 & 1.58 & $1.02-2.4$ & 0.03 \\
\hline
\end{tabular}

OR: odds ratio

\section{DISCUSSION}

This study investigated the morbidity pattern of $\mathrm{P}$. falciparum malaria during pregnancy in an area of New Halfa, which is characterized by unstable transmission (Himeidan et al., 2005). The malaria prevalence was $13.7 \%$ and 18 women $(17.6 \%)$ were severe cases. With the exception of the neighboring country Ethiopia (Newman et al., 2003), malaria prevalence was much lower than in other African countries characterized by intense malaria transmission (Rogerson et al., 2000; Bouyou-Akotet et al., 2003; Dicko et al., 2003). Several severe cases occurred in areas of unstable transmission, pregnant women are more susceptible to severe falciparum malaria than their nonpregnant peers (Luxemburger, 1997) and different manifestations of severe falciparum malaria including cerebral malaria have been reported among pregnant women of central Sudan (Adam et al., 2004).

The study showed no significant association between malaria and parity, which is also reported from other areas and locations with intense malaria transmission (Rogerson et al., 2000; Lander et al., 2002; Dicko et al., 2003). In areas where transmission is high and the level of acquired pregnancy immunity against malaria is expected to be significant, primigravidae will be more affected (Brabin, 1983; McGregor, 1984; Bouyou-Akotet et al., 2003).

In contrast to the previous observations (Rogerson et al., 2000; Bouyou-Akotet et al., 2003; Dicko et al., 2003), age was not significantly associated with malaria in the present study. Lander et al., have also reported no significant association between malaria infection and maternal age (Lander et al., 2002).

Women who attended the antenatal clinic in the third trimester had about a 1.5-fold higher risk of malaria parasitaemia. This is in line with some observations, although several studies report the second and early third trimesters as the time of peak prevalence (Brabin, 1983; Nosten et al., 1991; Menendez, 1995; Rogerson et al., 2000; Bouyou-Akotet et al., 2003; Dicko et al., 2003). Dicko et al., reported the first trimester as the main risk period ( Adam and Elbashir, 2005).

The mean haemoglobin was significantly lower in women with malaria infection and significantly lower in severe cases. Reduction of haemoglobin has been reported in areas of unstable transmission in Thailand and in Ethiopia, as well as in areas with stable transmission (Nosten et al., 1991; Newman et al., 2003). Regardless of transmission level and pre-pregnancy level of malaria immunity, maternal anaemia remains the most frequent consequence of malaria during pregnancy (Menendez, 1995).

\section{CONCLUSION}

The results suggest that prevalence of $P$. falciparum malaria is considerable in pregnant women in this part of Sudan and severe cases do occur. Preventive measures (chemoprophylaxis and 
insecticide-treated bednets) may be beneficial in this area for all women irrespective of their age or parity.

\section{ACKNOWLEDGMENTS}

We wish to thank all the patients for their excellent cooperation and we are very grateful to the local health authority in Kassala State and to the entire staff of New Halfa Teaching Hospital. Thanks are also extended to Mr. A. A. Hufazalla for his excellent technical assistance. 


\section{REFERENCES}

Adam I, Elbashir MI. (2004). Maternal death due to severe pulmonary edema caused by falciparum malaria: case report. East Mediterr Health J, 10: 685-688.

Adam I, Mirghani OM, Saed OK, Ahmed SM, Mohamadani AA, Ahmed HM, Mackenzie CD, Homeida MM, Elbashir MI. (2004a). Quinine therapy in severe Plasmodium falciparum malaria during pregnancy in Sudan. East Mediterr Health J, 10: 159-166.

Adam I, Elbashir MI. (2005). Comments on the article: Risk factors for malaria infection and anemia for pregnant women in the Sahel area of Bandiagara, Mali. Acta Trop, 96: 60-61.

Bouyou-Akotet MK, lonete-Collard DE, Mabika-Manfoumbi M, Kendjo E, Matsiegui P-B, Mavoungou E, Kombila M. (2003). Prevalence of Plasmodium falciparum infection in pregnant women in Gabon. Malar J, 2: 18.

Brabin BJ. (1983). Analysis of malaria in pregnancy in Africa. Bull World Health Organ, 61l: 10051016.

Dafallah SE, EL-Agib FH, Bushra GO. (2003). Maternal mortality in a teaching hospital in Sudan. Saudi Med J, 24: 369-373.

Dicko A, Mantel C, Aly Thera M, Doumbia S, Diallo M, Diakete M, Sagara I, Doumbo O. (2003). Risk factors for malaria infection and anemia for pregnant women in the Sahel area of Bandiagara, Mali. Acta Trop, 89: 17-23.

Himeidan YE, Elbashir MI, ELRayah E, Adam I. (2005). Epidemiology of malaria in an irrigated area in the eastern Sudan. East Mediterr Health J, 11: 499-504.

Lander J, Leroy V, Simonon A, Karita E, Bogaerats J, Clercq AD, Van de Perre P, Dabis F. (2002). HIV infection, malaria, and pregnancy: a prospective cohort study in Kigali, Rwanda. Am J Trop Med Hyg, 66: 56-60.

Luxemburger C, Ricci F, Nosten F, Raimond D, Bathet S, White NJ. (1997). The epidemiology of severe malaria in an area of unstable and low transmission in Thailand. Trans $R$ Soc Trop Med Hyg, 91: 256-262.

McGregor IA. (1984). Epidemiology, malaria and pregnancy. Am J Trop Med Hyg, 33: 517-525.

Menendez C. (1995). Malaria during pregnancy: A priority area of malaria research and control. Parasitol Today, 11: 178-183.

Newman RD, Hailemariam A, Jimma D, Degefie A, Kebede D, Rietveld AC, Nahlen BL, Barnwell JW, Steketee RW, Parise ME. (2003). Burden of malaria during pregnancy in areas of stable and unstable transmission in Ethiopia during a nonepidemic year. J Infect Dis, 187: 1765-1772.

Nosten F, Ter Kuile FO, Maelankirri L, Decludt B, White NJ. (1991). Malaria during pregnancy in an area of unstable endemicity. Trans R Soc Trop Med Hyg, 85: 424-429.

Okoko BJ, Enwere G, Ota MC. (2003). The epidemiology and consequences of maternal malaria: a review of immunological basis. Acta Trop, 87:193-205.

Rogerson SJ, Van den Broek NR, Chaluluka E, Qongwane C, Mhango CG, Molyneux ME. (2000). Malaria and anaemia in antenatal women in Blantyre, Malawi: a twelve- months survey. Am J Trop Med Hyg, 62: 335- 340.

Sahli H. (1984). Lehrbuch der Klinischen unter Suchungsmethoden. Leipzig: Deuticke

Shulman CE, Dorman EK. (2003). Importance and prevention for malaria in pregnancy. Trans R Soc Trop Med Hyg, 97: 30-35.

World Health Organization (2000). Severe falciparum malaria. Trans R Soc Trop Med Hyg, 94, (suppl 1). 



\section{Chapter 4}

Prevalence and risk factors for anaemia

in pregnant women of eastern Sudan

Published as: Adam I, Khamis AH, Elbashir MI. (2005). Prevalence and risk factors for anaemia in pregnant women of eastern Sudan. Trans R Soc Trop Med Hyg, 90: 739-743. 


\section{ABSTRACT}

\section{Background}

Pregnant women are more susceptible to anaemia, which is associated with adverse effects on pregnancy and poor maternal health. There is no published data concerning anaemia and pregnancy in Sudan.

\section{Aims}

The prevalence and possible risk factors for anaemia were investigated in 744 pregnant Sudanese women attending antenatal clinic of New Halfa teaching hospital, eastern Sudan between October 2003 and April 2004.

\section{Results}

466 (62.6\%) had anaemia (haemoglobin [Hb]: <11 gm/dl). 52.4\% had mild anaemia (Hb: 9.0-10.9 $\mathrm{gm} / \mathrm{dl}), 8.1 \%$ had moderate anemia $(\mathrm{Hb}: 7.0-8.9 \mathrm{gm} / \mathrm{dl})$, and $2.2 \%$ had severe anaemia $(\mathrm{Hb}:<$ $7 \mathrm{gm} / \mathrm{dl})$, respectively. The prevalence of anaemia $(73.2 \%)$ was significantly high in grandmultigravidae. Univariate and multivariate analysis showed that age and parity, were not significantly associated with anaemia. Malaria $(O R=4.5,95 \% \mathrm{Cl}=2.5-8.1 ; \mathrm{P}<0.0001)$ and pica $(O R$ $=1.6,95 \% \mathrm{Cl}=1.05-2.6 ; \mathrm{P}=0.03$ ) were the risk factors for anaemia.

\section{Conclusions}

Thus, preventive measures against malaria (chemoprophylaxis and insecticide-treated bednets) may be needed for all pregnant women irrespective to their age or parity. 


\section{BACKGROUND}

Over half of all women in the world experience anaemia during pregnancy with $95 \%$ occurring in the developing countries (DeMaeyer and Adiels-Tegman, 1985). Pregnant women are more susceptible to anaemia, which is associated with adverse effects on pregnancy and it has been reported as the risk factor for poor maternal health (Brabin, 1991; Brabin, 1992; Campbell and Abu Sham, 1995; Brabin and Piper, 1997; Santiso, 1997; Hagaz et al., 2003; Lone et al., 2004). The control of anaemia in women of reproductive age is one of the Safe Motherhood Initiatives (WHO, 1989).

Epidemiology of anaemia during pregnancy is important for deciding the control strategies. While this has been extensively studied in other African countries (Ndyomugyenyi and Magnussen, 1999; Rogerson et al., 2000; Bouyou-Akotet et al., 2003; Dicko et al., 2003; Newman et al., 2003) hardly any proper published data is available for Sudan, an African country with $\mathbf{4 0}$ million individuals and P. falciparum malaria with unstable transmission dominates its most parts including the eastern (Himeidan et al., 2005). The present study was conducted to investigate the prevalence and the risk factors for anaemia in pregnant women of eastern Sudan.

\section{METHODS}

The study was conducted between October 2003 and April 2004 at antenatal clinic (booking visit) of New Halfa teaching hospital, eastern Sudan. After taking the consent, a questionnaire form was used to gather relevant general informations and particularly on possible risk factors for anaemia: age, parity, pica (eating clay) and tonics use (ferrous /folic acid). Obstetrical examinations were performed and findings recorded (blood pressure, pallor, fundal level and fetal heart sound). The gestational age was calculated from the last menstrual period and confirmed by ultrasound in case of discrepancies.

\section{Haematology}

Thick and thin blood films were stained with Giemsa, examined using100 oil immersion fields and double-checked blindly. The haemoglobin concentration was estimated by the haematic acid method (Sahli, 1894) in the first two months and by Hemocue haemoglobinometer (HemoCue AB, Angelhom, Sweden) in the rest.

\section{Ethical clearance}

The study received ethical clearance from the Research Board at the Faculty of Medicine, University of Khartoum.

\section{Statistics}

Data were entered in computer using SPSS for windows and double-checked before analysis. Means and percentages were compared by Students' t-test, ANOVA, X2 and Fisher's exact tests as appropriate. $P<0.05$ was regarded as significant. Multivariate logistic regressions were performed with the presence of anaemia as a dependent variable and age, parity, pica, lack of tonics and malaria as possible influencing factors. The age and parity were categorized as follows: median age ( $\leq 25$ and $>25$ years), gravidity was categorized as primigravidae, secundigravidae, multigravidae (3-5) and grandmultigravidae ( $>5$ pregnancies).

\section{RESULTS}

\section{Anaemia and pregnancy}

A total of 744 pregnant women were investigated, 220 (29.5\%) were primigravidae, 144 (19.4\%) gave history of taking tonics, 108 (14.5\%) were practicing pica and $102(13.7 \%)$ had P. falciparum malaria.

Table (1) demonstrates the patients` presenting characteristics. 
A total 466 (62.6\%) had anaemia ([haemoglobin] $(\mathrm{Hb}):<11 \mathrm{gm} / \mathrm{dl} ; 52.4 \%, 8.1 \%$ and $2.2 \%$ had mild (Hb: 9-10.9 gm/dl), moderate $(7-8.9 \mathrm{gm} / \mathrm{dl}$ and severe anaemia $(\mathrm{Hb}:<7 \mathrm{gm} / \mathrm{dl})$, respectively. The prevalence $(73.2 \%)$ of anaemia was significantly high in grandmultigravidae and that of severe anaemia (6.1\%) was significantly high in secundigravidae, Table 1. There were no significant differences in the mean (SD) age [26.2 (5.6) vs. $25.6(4.8), P>0.05]$ and parity [2.3 (2.3) vs. 2.07 (1.9), $P>0.05]$ in the anaemic vs. non- anaemic women. $8(44.4 \%)$ of $18,163(56.2 \%)$ of 290 and $295(67.7 \%)$ of 436 women had anaemia in the first, second and third trimester, respectively, $P=$ 0.002 .

Table 1 characteristics of the study subjects and the prevalence of malaria and anaemia*

\begin{tabular}{llllllllllll}
\hline & & & \multicolumn{1}{l}{$\begin{array}{l}\text { The total } \\
\text { Variable }\end{array}$} & $\begin{array}{l}\text { Primi- } \\
\text { gravidae } \\
(N=220)\end{array}$ & $\begin{array}{l}\text { Secundi- } \\
\text { gravidae } \\
(N=131)\end{array}$ & $\begin{array}{l}\text { Multi- } \\
\text { gravidae } \\
(N=322)\end{array}$ & $\begin{array}{l}\text { Grand- } \\
\text { multigravidae } \\
(N=71)\end{array}$ & $P$. Value \\
\hline Age, years & 26.6 & $(9.9)$ & 21.2 & $(2.9)$ & 25.7 & $(2.3)$ & 28.2 & $(3.8)$ & 34.9 & $(3.2)$ & $<0.001$ \\
Gestation, weeks & 27.7 & $(7.7)$ & 27.3 & $(8.09)$ & 28.06 & $(6.9)$ & 27.6 & $(7.6)$ & 28.3 & $(28.3)$ & 0.18 \\
Haemoglobin, /dl & 10.5 & $(1.4)$ & 10.5 & $(1.3)$ & 10.3 & $(1.6)$ & 10.6 & $(1.3)$ & 10.3 & $(1.2)$ & 0.2 \\
Malaria & 102 & $(13.7)$ & 32 & $(14.5)$ & 14 & $(10.7)$ & 43 & $(13.4)$ & 13 & $(18.3)$ & 0.4 \\
Anaemia & 466 & $(62.6)$ & 141 & $(64.1)$ & 88 & $(67.2)$ & 185 & $(57.5)$ & 52 & $(73.2)$ & 0.03 \\
Mild & 390 & $(52.4)$ & 122 & $(55.5)$ & 66 & $(50.4)$ & 157 & $(48.8)$ & 45 & $(63.4)$ & 0.6 \\
Moderate & 60 & $(8.1)$ & 17 & $(7.7)$ & 14 & $(10.7)$ & 23 & $(7.1)$ & 6 & $(8.5)$ & 0.2 \\
Severe & 16 & $(2.2)$ & 2 & $(0.9)$ & 8 & $(6.1)$ & 5 & $(1.6)$ & 1 & $(1.4)$ & 0.01 \\
\hline
\end{tabular}

*Data as mean (SD) or number (\%) as appropriate.

\section{Risk factors for anaemia}

Univariate and multivariate analysis indicated that, age, parity, and lack of tonics were not significantly associated with anaemia. Grandmultigravidae was significantly associated with anaemia in univariate analysis, but this did not persist in multivariate analysis after removing the confounding factors.

Malaria $(O R=4.5,95 \% \mathrm{Cl}=2.5-8.1 ; \mathrm{P}<0.0001)$ and pica $(\mathrm{OR}=1.6,95 \% \mathrm{Cl}=1.05-2.6 ; \mathrm{P}=0.03$ were the risk factors for anaemia. The odds ratios and $95 \% \mathrm{Cl}$ of factors associated with anaemia using univariate and multivariate analysis were shown in Table2. 
Table 2 factors associated with anaemia in pregnant women of eastern Sudan using univariate or multivariate analysis.

\begin{tabular}{|c|c|c|c|c|c|c|}
\hline \multirow[b]{2}{*}{ The variable } & \multicolumn{3}{|c|}{ Univariate } & \multicolumn{3}{|c|}{ Multivariate } \\
\hline & OR & $95 \% \mathrm{Cl}$ & $P$ & OR & $95 \% \mathrm{Cl}$ & $P$ \\
\hline Age $\leq 25$ years & 1.38 & $0.75-2.5$ & 0.18 & 0.32 & $0.67-2.6$ & 0.4 \\
\hline \multicolumn{7}{|l|}{ Parity } \\
\hline Primigravidae & 1.09 & $0.79-1.52$ & 0.3 & 0.61 & $0.10-3.6$ & 0.59 \\
\hline Secundigravidae & 1.02 & $0.85-1.8$ & 0.14 & 0.76 & $0.13-4.5$ & 0.77 \\
\hline Multigravidae & 0.48 & $0.08-2.7$ & 0.41 & 0.74 & $0.37-1.4$ & 0.41 \\
\hline Grandmultigravidae & 1.73 & $1.002-2.9$ & 0.03 & 1.01 & $0.17-6.06$ & 0.9 \\
\hline Pica & 1.5 & $1.02-2.4$ & 0.02 & 1.65 & $1.05-2.6$ & 0.03 \\
\hline Lack of tonics & 1.09 & $0.74-1.58$ & 0.3 & 1.02 & $0.69-1.5$ & 0.9 \\
\hline Malaria & 4.47 & $2.4-7.9$ & 0.0001 & 4.5 & $2.5-8.1$ & 0.001 \\
\hline
\end{tabular}

\section{DISCUSSION}

The prevalence of anaemia in this study was $62.6 \%$ and $2.2 \%$ were severe cases; it might be less than this if the dry months were investigated as higher prevalence of anaemia was reported during wet seasons (Ndyomugyenyi and Magnussen, 1999; Rogerson et al., 2000; Dicko et al., 2003; Anya, 2004). With exception of the neighbor -Ethiopia- with its high altitude (Giles et al., 2003; Newman et al., 2003), the prevalence of anaemia in this study is comparable with that in other African countries (Ndyomugyenyi and Magnussen, 1999; Rogerson et al., 2000; Bouyou-Akotet et al., 2003; Dicko et al., 2003).

In this study there was no significant association between anaemia: age and gravidity; this goes with Dicko et al., 2003 findings. Grandmultigravidae was risk factor for anaemia in univariate analysis, but this did not persist in multivariate analysis after removing the confounding factors. Grandmultigravidae are expected to be older and repeated pregnancies/lactation would exhaust their iron storage. Interestingly, the prevalence of malaria in these women was not significantly different between the gravidity subgroups; this might be another explanation for the susceptibility of multigravidae to anaemia. This was not a community-based survey; and it is possible that women with problems (grandmultigravidae) were over represented in the antenatal clinic than their actual representation in the community. However, in other African countries with intense malaria transmission, primigravidae and secundigravidae were the risk factors for anaemia (Ndyomugyenyi and Magnussen, 1999; Rogerson et al., 2000; Bouyou-Akotet et al., 2003).

The study showed that, pica was significantly associated with anaemia, $(\mathrm{OR}=1.6,95 \% \mathrm{Cl}=1.05$ 2.6; $P=0.03$ ). Soil eating (pica) was reported as risk factor for maternal anaemia in the community of eastern Sudan (Adam et al., 2004a), African pregnant women practice pica widely, however; its effects on pregnancy outcomes were questioned (Geissler et al., 1998; Geissler et al., 1999; Rainville, 1998).

In this study women infected with P. falciparum malaria had 4.5-fold higher risk for anaemia. Several studies have reported malaria as primary reason for anaemia in pregnant women in other countries with unstable or stable malaria transmission (Nosten et al., 1991; Menendez, 1995; Ndyomugyenyi and Magnussen, 1999; Bouyou-Akotet et al., 2003; Dicko et al., 2003; Giles et al., 2003; Newman et al., 2003; Anya, 2004). In this study anaemia presented (co-exited) with malaria simultaneously. Interestingly, reduction of haemoglobin level followed malaria infection during pregnancy after sometime even if the malaria was effectively treated (Elghazali et al., 2004b), the explanation for this was unclear, although persistent placental parasitaemia after the clearance of peripheral one was a possibility (Sartelet et al., 1997). 
Malaria and pica were the major risk factors for anaemia; other possible risk factors for anaemia (education and income) were not investigated, if these were considered they might have influenced the results directly or as confounding factors.

Thus, preventive measures such as intermittant preventive therapy and insecticide treated nets may be needed in the area for all women irrespective to their age or parity especially during the rainy season

\section{ACKNOWLEDGEMENTS}

We wish to thank all the patients for their excellent co-operation and we are very grateful to the local health authority in Kassala State and to the entire Staff of New Halfa teaching hospital. Thanks are also extended to Mr. Abdalla A. Hufazalla for his excellent technical assistance. 


\section{REFERENCES}

Adam I, ElGhazali G, Mohamedin M, Elbashir MI. (2004a). Anaemia in Pregnant Sudanese Women: Community-Based Study. Saudi Med J, 25: 1119-1120.

Anya SE. (2004). Seasonal variation in the risk and causes of maternal death in the Gambia: malaria appears to be an important factor. Am J Trop Med Hyg, 70: 510-513.

Bouyou-Akotet MK, lonete-Collard DE, Mabika-Manfoumbi M, Kendjo E, Matsiegui P-B, Mavoungou E, Kombila M. (2003). Prevalence of Plasmodium falciparum infection in pregnant women in Gabon. Malaria J, 2: 18.

Brabin B. (1991). The risks and severity of malaria in pregnant women. Applied filed research in malaria, Report No.1 Geneva, World Health Organization.

Brabin B. (1992). Fetal anaemia in malarious area: its causes and significance. Ann Trop Med Ped, 12: 303-312.

Brabin B, Piper C. (1997). Anaemia and malaria attributable low birth weight in two populations in Papua New Guinea. Ann Hum Biol, 24: 547-555.

Campbell M, Abu Sham Z. (1995). Sudan: situational analysis of maternal health in Bara District, North Kordofan. World Health Stat Q, 48: 60-66.

DeMaeyer E, Adiels-Tegman M. (1985). The prevalence of anaemia in the world. World Health Stat Q, 85: 302-316.

Dicko A, Mantel C, Aly Thera M, Doumbia S, Diallo M, Diakete M, Sagara I, Doumbo O. (2003). Risk factors for malaria infection and anemia for pregnant women in the Sahel area of Bandiagara, Mali. Acta Tropica, 89: 17-23.

EIGhazali G, Adam I, Hamad AA, Elbashir M I. (2003). Malaria and pregnancy in an area of unstable transmission in eastern Sudan. East Mediterr Health J, 9: 571-580.

Geissler PW, Prince RJ, Levene M, Poda C, Beckerleg SE, Mutemi W, Shulman CE. (1999). Perceptions of soil- eating and anaemia among pregnant women on the Kenyan coast. Soc Sci Med, 48: 1069-1079.

Geissler PW, Shulman CE. Prince RJ, Mutemi W, Mnazi C, Friss HB. (1998). Geophagy, iron status and anaemia among pregnant women on the coast of Kenya. Trans R Soc Trop Med Hyg, 92: 549-553.

Giles S, Brabin BJ, Yassin MA, Cuevas LE. (2003). Comparison of screening method for anaemia in pregnant women in Awassa, Ethiopia. Trop Med Int Health, 8: 301-309.

Hagaz AA, Mirghani O, Adam I. (2003). Venous thromboembolism in pregnancy and puerperium in Sudanese women. Int J Gynecol Obstet, 83: 309-310.

Himeidan YE, Elbashir MI, ELRayah E, Adam I. (2005). Epidemiology of malaria in an irrigated area in the eastern Sudan. East Mediterr Health J, 11: 499-504.

Lone FW, Qureshi RN, Emanuel F. (2004). Maternal anaemia and its impact on perinatal outcome. Trop Med Int Health, 9: 486-490.

Menendez C. (1995). Malaria during pregnancy: A priority area of malaria research and control. Parasitology Today, 11: 178-183.

Ndyomugyenyi R, Magnussen P. (1999). Anaemia in pregnancy: Plasmodium falciparum infection is an important cause in primigravidae in Homina district, western Uganda. Ann Trop Med Parasitol, 93: 457-465.

Newman RD, Hailemariam A, Jimma D, Degefie A, Kebede D, Rietveld AC, Nahlen B L, Barnwell JW, Steketee RW, Parise ME. (2003). Burden of malaria during pregnancy in areas of stable and unstable transmission in Ethiopia during a nonepidemic year. J Infect Dis, 187: 1765-1772.

Nosten F, Ter Kuile FO, Maelankirri L, Decludt B, White NJ. (1991). Malaria during pregnancy in an area of unstable endimicity. Trans R Soc Trop Med Hyg, 85: 424-429.

Rainville AJ. (1998). Pica practices of pregnant women are associated with lower maternal haemoglobin level at delivery. J Am Diet Assoc, 98: 293-296. 
Rogerson SJ, Van den Broek NR, Chaluluka E, Qongwane C, Mhango CG, Molyneux ME. (2000). Malaria and anaemia in antenatal women in Blantyre, Malawi: A twelve- months survey. Am J Trop Med Hyg, 62: 335-340.

Sahli H. (1894). Lehrbuch der Klinischen unter Suchungsmethoden. Leipzig: Deuticke.

Santiso R. (1997). Effects of chronic parasitosis on women's health. Int J Gynecol Obstet, 58: 129136.

Sartelet H, Milko-Sartelet I, Garraud O, Picot S. (1997). Plasmodium falciparum persists in the placenta after three days' treatment with quinine. Trans R Soc Trop Med Hyg, 91: 431-435.

World Health Organization. (1989). Report of the African regional consultation on control of anaemia during pregnancy. Brazzaville: WHO Regional Office for Africa. 


\section{Chapter 5}

$A B O$ blood group system and placental malaria in an area of unstable malaria transmission in eastern Sudan

Published as: Adam I, Babiker S, Mohmmed AA, Salih MM, Prins MH, Zaki ZM. (2007). $A B O$ blood group system and placental malaria in an area of unstable malaria transmission in eastern Sudan. Malaria J, 10; 6(1):110 


\begin{abstract}
Background

Understanding the pathogenesis of malaria in pregnancy and its consequences for both the mother and the baby is fundamental for improving malaria control in pregnant women.
\end{abstract}

\title{
Aims
}

The study aimed to investigate the role of $A B O$ blood groups on pregnancy outcomes in an area of unstable malaria transmission in eastern Sudan.

\section{Methods}

A total of 293 women delivering in New Half teaching hospital, eastern Sudan during the period October 2006-March 2007 have been analyzed. ABO blood groups were determined and placental histopathology examinations for malaria were performed. Birth and placental weight were recorded and maternal haemoglobin was measured.

\section{Results}

114 (39.7\%), 61 (22.1\%) and 118 (38.2\%) women were primiparae, secundiparae and multiparae, respectively. The $A B O$ blood group distribution was $82(A), 59(B), 24(A B)$ and $128(O)$. Placental histopathology showed acute placental malaria infections in $6(2 \%)$, chronic infections in $6(2 \%), 82$ (28.0\%) of the placentae showed past infection and $199(68.0 \%)$ showed no infection. There was no association between the age $(O R=1.02,95 \% \mathrm{Cl}=0.45-2.2 ; \mathrm{P}=0.9)$, parity $(\mathrm{OR}=0.6,95 \% \mathrm{Cl}=0.3$ 1.2; $P=0.1$ ) and placental malaria infections. In all parity blood group $O$ was associated with a higher risk of past $(O R=1.9,95 \% \mathrm{Cl}=1.1-3.2 ; \mathrm{P}=0.01)$ placental malaria infection. This was also true when primiparae were considered separately $(\mathrm{OR}=2.6,95 \% \mathrm{Cl}=1.05-6.5, \mathrm{P}=0.03)$.

Among women with all placental infections / past placental infection, the mean haemoglobin was higher in women with the blood group $\mathrm{O}$, but the mean birth weight, feto-placental weight ratio was not different between these groups and the non- $O$ group.

\section{Conclusion}

These results indicate that women of eastern Sudan are at risk for placental malaria infection irrespective to their age or parity. Those women with blood group $\mathrm{O}$ were at higher risk of past placental malaria infection. 


\section{BACKGROUND}

It has been estimated that $90 \%$ of the global malaria burden occurs in sub-Saharan Africa, where $40 \%$ women are exposed to malaria infections during pregnancy (Steketee et al., 2001). Malaria during pregnancy poses a substantial risk to the mother, her foetus and the neonate (Cot et al., 2003): it is a major health problem in Sudan, where it has been reported to be associated with maternal anaemia, low birth weight infants and a major cause of maternal mortality (Taha et al., 1993; Dafallah et al., 2003; Adam et al., 2005a; Adam et al., 2005b).

Host genetic factors modulate the risk and severity of infection via specific mediators, which can be different in various epidemiological settings. Cell adhesion plays a fundamental role in placental malaria pathophysiology (Costa et al., 2003). Cell surface glycans, such as the $A B O$ and related antigens could modulate some of those specific cell interactions (Cserti et al., 2007). A century since the discovery of the $\mathrm{ABO}$ blood groups, numerous associations between $\mathrm{ABO}$ groups and disease have been reported. Interestingly, some strains of Plasmodium falciparum preferentially trigger rosette formation depending on the red blood cell blood group (Barragan et al., 2000). However, the rosette formation is not a feature of $P$. falciparum infections during pregnancy (Maubert et al., 1998).

Recently, $A B O$ blood groups have been reported to be one of the host risk factors for placental malaria infections and also to be associated with other materno-foetal outcomes (Loscertales and Brabin, 2006). The current study was conducted in eastern Sudan, an area that is characterized by unstable malaria transmission (Himeidan et al., 2005) and where malaria is a substantial burden affecting pregnant women irrespective to their age or parity (Adam et al., 2005a). The study aimed to investigate the epidemio-pathogical characteristics of placental malaria infections with special attention to blood groups and their association with materno-fetal outcomes and to add to the ongoing data on the pathogenesis of malaria during pregnancy in the area (Adam et al., 2007).

\section{METHODS}

\section{Patients}

The study was conducted between October 2006 and March 2007, at the labour ward of New Halfa Teaching Hospital, eastern Sudan. After informed consent, women with a singleton baby were approached to participate in the study. Those with antepartum haemorrhage, hypertensive disorder of pregnancy (diastolic blood pressure $>90 \mathrm{~mm} \mathrm{Hg}$ ) and diabetes mellitus were excluded. A structured questionnaire was administered to collect information about socio-demographic characteristics, mode of delivery and birth outcome. Obstetrical examinations were performed and the findings recorded (blood pressure, pallor, fundal level and foetal heart sound). The babies were weighted immediately following birth on a Salter scale to the nearest $10 \mathrm{~g}$; scales were checked for accuracy on a weekly basis.

\section{Haematology}

Maternal, placental and cord blood films were prepared, the slides were Giemsa-stained and the number of asexual P. falciparum parasites per 200 white blood cells was counted and doublechecked blindly by an expert microscopist. Maternal haemoglobin concentrations were estimated by HemoCue haemoglobinometer (HemoCue AB, Angelhom, Sweden). Maternal blood groups were investigated by the agglutination method.

\section{Histopathology}

Full thickness placental blocks of around $2-3 \mathrm{~cm}$ were taken from the placenta, kept in neutral buffer formalin for histopathology examinations. Placental malaria infections were characterized based on the classification of Bulmer et al., (1994): uninfected (no parasites or pigment), acute (parasites in intervillous spaces), chronic (parasites in maternal erythrocytes and pigment in fibrin 
or cells within fibrin and/or chorionic villous syncytiotrophoblast or stroma), past (no parasites and pigment confined to fibrin or cells within fibrin).

\section{Statistics}

Data were entered in computer using SPSS for windows and double-checked before analysis. Means and percentages were compared either by Students' t-test, ANOVA ( if data were normally distributed) or by the Mann-Whitney test (if the data were not normally distributed). $X^{2}$ and Fisher's exact tests as appropriate. Multiple linear regressions were used to analyze placental malaria infections as a dependent variable and age $<19$ years, parity (primiparae, secundiparae and multiparae) and maternal blood group ( $O$ versus non $O$ ) as possible influencing factors. The others factors included in the analyses were: maternal blood group ( $O$ versus non $O$ ), parity, placental infection, maternal haemoglobin, birth weight and foeto-placental ration. $P \leq 0.05$ was regarded as significant.

\section{Ethics}

The study received ethical clearance from the Research Board at the Faculty of Medicine, University of Khartoum.

\section{RESULTS}

During the study period, there were 578 deliveries. Of these, 24 were twins and four were triplets, 550 singleton deliveries. The data of placental histopathology, maternal haemoglobin, placental and birth weight were complete in 293 women; these data were included in the final analyses. Out of these 293 women, there were 114 (39.7\%), 61 (22.1\%) and 118 (38.2\%) primiparae, secundiparae and multiparae, respectively. The mean (SD) age was $25.6(6.4)$ years and $57(19.4 \%)$ of the women were teenagers (age $\leq 19$ years). Of the 293 women, $82(28.0 \%), 59(20.1 \%), 24$ (8.2\%) and $128(43.7 \%)$ had blood group A, B, AB and O, respectively. The mean (SD) haemoglobin was 11.4 (2.1) $\mathrm{gm} / \mathrm{dl}$. The mean (SD) birthweight was 3,063.4 (545.4) $\mathrm{gm}$, while the mean feto/placental ratio was 5.6 (1.2). Maternal and placental blood films were positive in four cases and the blood films for malaria were positive in one maternal, placental and cord setting.

Six (2\%), 6 (2\%) and $82(28.0 \%)$ of the placentae showed acute, chronic, past infection on histopathology examination respectively, while $199(68.0 \%)$ of them showed no infection. There were no associations between the age $(O R=1.02,95 \mathrm{Cl}=0.45-2.2 ; \mathrm{P}=0.9)$, parity $(\mathrm{OR}=0.6,95$ $\mathrm{Cl}=0.3-1.2 ; \mathrm{P}=0.1$ ) and placental infections (all or in subgroups).

Women who have blood group $O$ were at higher risk for past placental infections $(O R=1.9,95$ $\mathrm{Cl}=1.1-3.2 ; \mathrm{P}=0.01)$. This was also true when primiparae were considered separately $(\mathrm{OR}=2.6,95 \%$ $\mathrm{Cl}=1.05-6.5, \mathrm{P}=0.03$, Table 1 .

Past placental malaria infections were observed in 45 (35.2\%) of 128 women with blood group $O$ versus $37(22.4 \%)$ of 165 with non- $O$ group, $P=0.01$. This was also true when primiparae were considered separately, $16(31.4 \%)$ of 51 primiparae women with group $O$ versus $10(15.9 \%)$ of 63 with non- group $\mathrm{O}, \mathrm{P}=0.05$, (Table 2 ).

The mean birth weight and feto-placental ratio were not significantly different between those with and without placental malaria infections or those women with blood group $\mathrm{O}$ and non- $\mathrm{O}$ group, (Table 2).

Maternal haemoglobin concentration was significantly higher in $\mathrm{O}$ type mothers with all placental /past placental malaria (11.8 $\mathrm{g} / \mathrm{dl}$, versus $10.9 \mathrm{~g} / \mathrm{dl}, \mathrm{P}=0.02)$, this difference was statistically significant even when primiparae were considered separately $(12.0 \mathrm{~g} / \mathrm{dl}$, versus $10.4 \mathrm{~g} / \mathrm{dl}, \mathrm{P}=0.05)$, (Table 2). 
Table $1 \mathrm{ABO}$ phenotype by placental malaria category and parity group

\begin{tabular}{|c|c|c|c|c|c|c|c|c|c|c|}
\hline \multirow{3}{*}{ Parity } & \multicolumn{10}{|c|}{ Placental malaria } \\
\hline & \multirow[t]{2}{*}{ Type } & \multirow[t]{2}{*}{ number } & \multicolumn{7}{|c|}{ Blood group Phenotype } & \\
\hline & & & $A$ & & B & & $A B$ & & $\mathrm{O}$ & \\
\hline \multirow[t]{5}{*}{ Total } & Acute & 6 & 5 & $(6.1)$ & 1 & (1.7) & 0 & (0) & 0 & $(0)$ \\
\hline & Chronic & 6 & 2 & $(2.4)$ & 1 & (1.7) & 1 & $(4.2)$ & 2 & $(1.6)$ \\
\hline & Past & 82 & 19 & $(23.2)$ & 13 & $(22.0)$ & 5 & $(20.8)$ & 45 & $(35.2)^{*}$ \\
\hline & None & 199 & 56 & $(68.3)$ & 44 & $(74.6)$ & 18 & (75) & 81 & $(63.3)$ \\
\hline & Total & 293 & 82 & & 59 & & 24 & & 128 & \\
\hline Primi- & Acute & 2 & 2 & $(6.5)$ & 0 & $(0)$ & 0 & (0) & 0 & $(0)$ \\
\hline \multirow[t]{4}{*}{ parae } & Chronic & 1 & 0 & $(0)$ & 0 & (0) & 1 & $(12.5)$ & 0 & (0) \\
\hline & Past & 26 & 5 & $(16.1)$ & 3 & $(12.5)$ & 2 & $(25.0)$ & 16 & $(31.4)^{\star}$ \\
\hline & None & 85 & 24 & (77.4) & 21 & $(87.5)$ & 5 & $(62.5)$ & 35 & (68.6) \\
\hline & Total & 114 & 31 & & 24 & & 8 & & 51 & \\
\hline Secundi- & Acute & 2 & 1 & $(4.2)$ & 1 & (12.5) & 0 & (0) & 0 & (0) \\
\hline \multirow[t]{4}{*}{ parae } & Chronic & 0 & 0 & (0) & 0 & (0) & 0 & (0) & 0 & (0) \\
\hline & Past & 18 & 8 & (33.3) & 0 & (0) & 0 & (0) & 10 & (38.5) \\
\hline & None & 41 & 15 & (62.5) & 7 & (87.5) & 3 & $(100)$ & 16 & (61.5) \\
\hline & Total & 61 & 24 & & 8 & & 3 & & 26 & \\
\hline Multi- & Acute & 2 & 2 & (7.4) & 0 & & 0 & & 0 & \\
\hline \multirow[t]{4}{*}{ parae } & Chronic & 5 & 2 & (7.4) & 1 & (3.7) & 0 & & 2 & (3.9) \\
\hline & Past & 38 & 6 & (22.2) & 10 & (37) & 3 & $(23.1)$ & 19 & (37.3) \\
\hline & None & 73 & 17 & $(63.0)$ & 16 & (59.3) & 10 & (76.9) & 30 & (58.8) \\
\hline & Total & 118 & 27 & & 27 & & 13 & & 51 & \\
\hline
\end{tabular}

* Significant difference

Table 2 mean (SD) maternal and birth outcomes by parity and maternal blood group phenotype

\begin{tabular}{llllllll}
\hline Parity & \multicolumn{7}{l}{ Maternal and foetal parameters } \\
& $\begin{array}{l}\text { Placental } \\
\text { malaria type }\end{array}$ & $\begin{array}{l}\text { Blood } \\
\text { group }\end{array}$ & $\begin{array}{l}\text { num- } \\
\text { ber }\end{array}$ & Maternal Hb & Birth weight & $\begin{array}{l}\text { Foeto- } \\
\text { placental } \\
\text { ratio }\end{array}$ \\
\hline All parity & Infection & Group O & 47 & $11.8(2.1)^{\star}$ & $3060.1(370.0)$ & $5.4(1.0)$ \\
& & Non- O & 47 & $10.9(1.9)$ & $310.9(575.4)$ & $5.6(1.0)$ \\
& No infection & Group O & 81 & $11.5(2.1)$ & $3098.3(561.6)$ & $5.7(1.1)$ \\
& & Non- O & 118 & $11.6(2.2)$ & $3037.2(554.2)$ & $5.6(1.4)$ \\
\hline Primi- & Infection & Group O & 16 & $12.0(2.0)^{*}$ & $2946.4(367.2)$ & $5.6(0.8)$ \\
parae & & Non- O & 13 & $10.4(2.3)$ & $2898.3(409.7)$ & $5.7(0.9)$ \\
& No infection & Group O & 35 & $11.1(2.1)$ & $3065.4(462.4)$ & $5.8(1.0)$ \\
& & Non- O & 50 & $11.7(2.3)$ & $3019.8(593.9)$ & $5.8(1.8)$ \\
\hline Secundi- & Infection & Group O & 10 & $11.1(2.5)$ & $3150.1(348.4)$ & $5.7(0.3)$ \\
parae & & Non- O & 10 & $11.0(1.2)$ & $3298.6(655.0)$ & $5.5(1.3)$ \\
& No infection & Group O & 16 & $11.5(1.9)$ & $3251.2(570.5)$ & $6.0(1.2)$ \\
& & Non- O & 25 & $12.1(2.1)$ & $2947.4(529.9)$ & $5.4(1.0)$ \\
\hline Multi- & Infection & Group O & 21 & $12.0(2.0)$ & $3098.5(379.2)$ & 5.1 & $(0.98)$ \\
parae & & Non- O & 24 & $11.1(2.0)$ & $3038.0(604.4)$ & $5.5(1.3)$ \\
& \multirow{2}{*}{ No infection } & Group O & 30 & $11.9(2.1)$ & $3055.6(656.9)$ & $5.4(1.1)$ \\
& & Non- O & 43 & $11.2(2.0)$ & $3109.524 .8)$ & $5.3(0.9)$ \\
\hline
\end{tabular}

* Significant difference 


\section{DISCUSSION}

As in previous findings on the peripheral microscopically- and submicroscopically-detected parasitaemia and the pathogenesis of malaria during pregnancy in the same hospital (Adam et al., 2005a; Adam et al., 2005c; Adam et al., 2007), the histopathological placental malaria infections were not associated with age or parity in the current study. The explanation for this may be the low immunity in the area, which is characterized by unstable malaria transmission (Himeidan et al., 2005).

In this study around $32 \%$ of the placentae had been observed to have some degree of infections, few of these infections were acute while the vast majority was past infections. Women (even primiparae) with blood group $\mathrm{O}$ were at higher risk for past placental malaria infections. While significantly higher haemoglobin was observed in women with past placental malaria and blood group $\mathrm{O}$, the other parameters (birth weight and foeto-placental ration) were not different between the two groups. Surprisingly, in this study the birthweight was not associated with histopathological placental malaria infections and the explanation for this remains unclear. These women had very low prevalence of peripheral, placental and cord microscopically detected parasitaemia, hence the role of submicroscopic parasitaemia on low birthweight cannot be excluded. Previously, a large burden of submicroscopically-detected parasitaemia was observed to be associated with morbidity and mortality among pregnant and non-pregnant individuals in the same geographical area (Adam et al., 2005c; Giha et al., 2005).

Recently, Loscertales and Brabin (2006) have observed that; in primiparae, blood group $O$ was associated with a higher risk of acute infection and a lower risk of past infection, in contrary to multiparae in whom $O$ phenotype was associated with reduced prevalence of acute or past placental infection. However, findings from other studies suggested that individuals of blood group $O$ are relatively resistant to severe disease caused by $P$. falciparum infection. It was established that parasitized erythrocytes form rosettes more readily with red blood cells (RBCs) of $A$, $B$, or $A B$ groups than with blood group $O$ and this parasite-triggered $R B C$ rosette formation is associated with the severity of clinical disease and with the development of cerebral malaria (Pathirana et al., 2005; Uneke, 2007). Pregnant women are more attractive for the vector (Himiedan et al., 2004) - and a differential affinity of blood group $O$ for the vector has also been reported before (Wood, 1974). Furthermore, an antigen sharing between $A B O$ phenotypes and $P$. falciparum leading to changes in immune response (Athreya and Coriell L, 1976) or facilitating entry of the parasite into the red cell has been described recently (Podbielska et al., 2004).

In the current study, women with past placental infection had higher mean haemoglobin when they were of $O$ blood group. This correlates with the previous findings where non- pregnant patients with severe $\mathrm{P}$. falciparum malaria and non-O blood group had significantly lower haemoglobin levels compared with patients with group O blood (Fischer and Boone 1998). The higher Hb level associated with the $\mathrm{O}$ phenotype could relate to the development of improved malaria immunity in this particular group of women, following on from a preceding increased risk of malaria infection in this phenotype. Recently, Loscertales and Brabin (2006) have also reported higher (although, not statistically significant ) haemoglobin in women with blood group $\mathrm{O}$.

\section{CONCLUSIONS}

These results indicate that women of eastern Sudan are at risk for placental malaria infection irrespective to their age or parity. Those with blood group $\mathrm{O}$ were at higher risk of past -chronic placental malaria infection. Among women with past- chronic placental infection, the mean haemoglobin was higher in women with the $\mathrm{O}$ blood group, but the mean birthweight and foetoplacental weight ratio were not significantly different between these groups. 


\section{ACKNOWLEDGMENTS}

We wish to thank all the patients for their excellent cooperation and we are very grateful to the local health authority in Kassala State and to the entire staff of New Halfa Teaching Hospital.This work has been supported by Sudanese Sugar Company. 


\section{REFERENCES}

Adam I, Khamis AH, Elbashir MI. (2005a). Prevalence and risk factors for malaria in pregnant women of eastern Sudan. Malar J, 4: 8.

Adam I, Khamis AH, Elbashir MI. (2005b). Prevalence and risk factors for anaemia in pregnant women of eastern Sudan. Trans R Soc Trop Med Hyg, 90: 739-743.

Adam I, AlElbasit IE , Salih I, Elbashir MI. (2005c). Submicroscopic Plasmodium falciparum infections during pregnancy, in an area of Sudan with low malaria transmission. Ann Trop Med Parasitol, 99:339-344.

Adam I, Nour BY, Ibrahim EY, Almahi WA, Omer EM, Ali NY. (2007). Cortisol and susceptibility to malaria in pregnant women in an area of unstable malaria transmission in eastern Sudan, Intern J Gynecol Obstet, 98: 260-261.

Athreya BH, Coriell L. (1967). Relation of blood groups to infection. Survey and review of data suggesting possible relationship between malaria and blood groups. Am J Epidemiol ,86: 292 304.

Bulmer JN, Rasheed FN, Francis N, Morrison L, Greenwood BM. (1993). Placental malaria. I. Pathological classification. Histopathology, 22: 211-218.

Cot M, Deloron P. (2003). Malaria during pregnancy: consequences and interventional perspectives. Med Trop, 63: 369-380.

Costa FT, Fusai T, Parzy D, Sterkers Y, Torrentino M, Douki JB, Traore B, Petres S, Scherf A, Gysin J. (2003). Immunization with recombinant duffy binding-like-gamma3 induces pan-reactive and adhesion-blocking antibodies against placental chondroitin sulfate A-binding Plasmodium falciparum parasites. J Infect Dis, 188:153-164.

Cserti CM, Dzik WH. (2007). The ABO blood group system and Plasmodium falciparum malaria. Blood, 110: 2250-2258.

Dafallah SE, EL-Agib FH, Bushra GO. (2003). Maternal mortality in a teaching hospital in Sudan. Saudi Med J, 24: 369-373.

Fischer PR, Boone P. (1998). Short report: severe malaria associated with blood group. Am J Trop Med Hyg, 58: 122-123.

Giha HA, A-Elbasit IE, Elgadir TM, Adam I, Berzins K, Elghazali G, Ebashir M I. (2005). Cerebral malaria is frequently associated with latent parasitemia among the semi-immune population of eastern Sudan. Microbes Infect, 7:1196-1203.

Himiedan YE, Elbashir MI, Adam I. (2004). Attractiveness of pregnant Sudanese women to malarial vector-Anopheles arabiensis, Ann Trop Med Parasitol, 98: 631-633.

Himeidan YE, Malik EM, Adam I. (2005). Epidemiology and seasonal pattern of malaria in an irrigated area of eastern Sudan. Am J Inf Dis, 1: 75-78.

Loscertales MP, Brabin BJ. (2006). ABO phenotypes and malaria related outcomes in mothers and babies in The Gambia: a role for histo-blood groups in placental malaria. Malar J, 5: 72.

Maubert B, Fievet N, Tami G, Boudin C, Deloron P. (1998). Plasmodium falciparum-isolates from Cameroonian pregnant women do not rosette. Parasite, 5: 281-283.

Pathirana SL, Alles HK, Bandara S, Phone-Kyaw M, Perera MK, Wickremasinghe AR, Mendis KN, Handunnetti SM. (2005). ABO-blood-group types and protection against severe, Plasmodium falciparum malaria Ann Trop Med Parasitol, 99:119-124.

Podbielska M, Fredriksson SA, Nilsson B, Lisowska E, Krotkiewski H. (2004). ABH blood group antigens in O-glycans of human glycophorin A. Arch Biochem Biophys, 429:145-153.

Steketee RW, Nahlen BL, Parise MF, Menendez C. (2001). The burden of malaria in pregnancy in malaria-endemic areas. Am J Trop Med Hyg 64 (Suppl.): 28-35.

Taha ET, Ronald HG, Abdalla AM. (1993). Malaria and low birth weight in central Sudan. Am J Epidemiol, 138: 315-325.

Uneke CJ. (2007). Plasmodium falciparum malaria and ABO blood group: is there any relationship? Parasitol Res., 100: 759-765. 
Wood CS. (1974). Preferential feeding of Anopheles gambiae mosquitoes on human subjects of blood group O: A relationship between the $A B O$ polymorphism and malaria vectors. Hum Biol, 46: 385-404. 



\title{
Chapter 6
}

Low body mass index, anaemia and poor perinatal outcome in

\author{
a rural hospital in eastern Sudan
}

Published in part as: Adam I, Babiker S, Mohmmed A. A, Salih M.M, Martin H Prins M H, Zaki Z M. (2007). Low body mass index, anaemia and poor perinatal outcome in a rural hospital in eastern Sudan. Journal of Tropical pediatrics, in press. 


\section{ABSTRACT}

\section{Background}

Though there is an extensive literature on the perinatal outcome from several African countries, yet few reports have been published from the Sudan.

\section{Aims}

The study was conducted during October 2006-March 2007 at New Halfa teaching hospital, eastern Sudan to investigate the prevalence and possible risk factors for a poor perinatal outcome, defined as low birth weight (LBW), APGAR score $<5$ at $1 \mathrm{~min}$, fetal anaemia and perinatal mortality.

\section{Results}

LBW occurred in $15.3 \%$, the perinatal death occurred in $9.2 \%$.

Maternal low body mass index (BMI) was significantly associated with $\mathrm{LBW}(\mathrm{OR}=2.3,95 \% \mathrm{Cl}=1.0$ 5.1; $P=0.02)$, which was a risk factor for APGAR score $<5$ at $1 \mathrm{~min}(\mathrm{OR}=6.9,95 \% \mathrm{Cl}=2.8-16.8 ; P<$ $0.000)$ and perinatal mortality $(\mathrm{OR}=309,95 \% \mathrm{Cl}=29.2-3271.1, P<0.00001)$. Maternal anaemia was a risk factor for fetal anaemia $(O R=2.2,95 \% \mathrm{Cl}=1.2-3.9 ; P=0.006)$ and APGAR score $<5$ at 1 $\min (\mathrm{OR}=0.48,95 \% \mathrm{Cl}=0.23-0.99 ; P=0.04)$.

\section{Conclusion}

More attention to maternal nutrition in an attempt to prevent anaemia may lead to improvement in the perinatal outcome. 


\section{INTRODUCTION}

Perinatal outcome is an important indicator of overall level of obstetric care, health status and socio-economic development. It is estimated that annually four million infants die during the first month of life worldwide (SNL, 2001). The vast majority of these neonatal deaths occur in poor countries where standards of both maternal and neonatal care are low. One of the Millennium Development Goals is to reduce the number of childhood deaths under the age of five years by two thirds from 95 per 1000 to 31 per 1000 by 2015 (UN, 2001). If the Millennium Development Goal of significantly reducing childhood deaths is to be achieved, a substantial reduction in early neonatal deaths will be required, especially in poor countries. The first steps in improving early neonatal survival are to document the number and rate of deaths during the first week, identify the common causes and look for modifiable factors. These factors usually intermingle with each other and hence can influence perinatal outcome directly or indirectly (Verhoeff, et al., 2004; le Cessie et al., 2002; Brabin and Piper, 1997).

Addressing maternal and newborn health in rural parts of Africa offers particular challenges because of the inadequate public health infrastructure and the distance of communities from facilities providing skilled care. Also, program managers lack access to local data for basic indicators such as low birth weight (LBW), fetal anaemia and perinatal deaths. A local surveillance database to more accurately assess perinatal outcome would enhance our epidemiologic knowledge and could help health care managers to understand more fully the causes of poor pregnancy outcomes as well as identify areas to which interventions should be targeted, and monitor the effectiveness of these interventions over time. In addition it would provide indicators of underlying causes and suggests the types of prevention and interventions that should be implemented. An obvious example is preventing deaths of LBW babies which requires the use of technologically advanced treatment methods associated with neonatal intensive care. This level of care is clearly not feasible for such a population. Interventions therefore could focus on decreasing LBW preemptively by e.g. improving maternal nutrition and preventing malaria and anaemia.

The prevalence of perinatal outcomes (LBW, Low AGPAR score, fetal anaemia and perinatal death) and their risk factors are not well known in Sudan in general and in the eastern part of the country in particular. The aim of the current study was to identify and quantify risk factors for poor perinatal outcome in a rural hospital in eastern Sudan and to assess the role of socio-demographic factors and maternal illnesses such as malaria and anaemia.

\section{MATERIALS AND METHODS}

\section{Patients}

The study was conducted between October 2006 through March 2007 at the labour ward of New Halfa teaching hospital, eastern Sudan. After an informed consent, women with a singleton baby had been approached to participate in the study; those with antepartum hemorrhage, hypertensive disorder (diastolic blood pressure $>90 \mathrm{~mm} \mathrm{HG}$ ) and diabetes mellitus were excluded.

A structured questionnaire was administered to each woman to collect information on sociodemographic markers like residence, educational, age, parity, antenatal attendance, mode of delivery, birth outcome and condition of her baby. Maternal weight and height (in bare feet and with no head cover), were measured to the nearest centimeter after delivery and expressed as body mass index (BMI - weight $(\mathrm{kg}) /$ height $(\mathrm{m})^{2}$ ).

Babies were weighed immediately after birth on a Salter scale to the nearest $10 \mathrm{~g}$; scales were checked for accuracy on weekly basis. The APGAR score at $1 \mathrm{~min}$ was also recorded. In order to estimate the perinatal mortality, babies were followed until day seven postpartum.

\section{Haematology}

Maternal, placental and cord thick blood films were prepared. The slides were Giemsa stained and read counting the number of asexual Plasmodium falciparum parasites per 200 white blood cells 
and double checked blindly by an expert microscopist. Materernal and cord haemoglobin concentrations were estimated by Hemocue haemoglobinometer (HemoCue AB, Angelhom, Sweden).

\section{Histopathology}

Full thickness placental blocks of around $2-3 \mathrm{~cm}$ were taken from the placentae, kept in neutral buffer formalin for histopathology examinations. Placental malaria infections was based on the pathological classification of Bulmer et al (1997): uninfected (no parasites or pigment), acute (parasites in intervillous spaces), chronic (parasites in maternal erythrocytes and pigment in fibrin or cells within fibrin and/or chorionic villous syncytiotrophoblast or stroma), past (no parasites and pigment confined to fibrin or cells within fibrin).

\section{Definitions}

Maternal anaemia was defined as a haemoglobin concentration $<11 \mathrm{gm} / \mathrm{dl}$ and severe anaemia as a haemoglobin concentration $<7 \mathrm{gm} / \mathrm{dl}$. Fetal anaemia was defined as cord haemoglobin $<12.5$ $\mathrm{gm} / \mathrm{dl}$. LBW was defined as birth weight less than $2500 \mathrm{gm}$. Perinatal mortality was defined as death from 28-week gestational age (in-utero or outside) till 7 days after birth.

\section{Statistics}

Data were entered in computer using SPSS for windows and double-checked before analysis. Means and percentages were calculated. $P<0.05$ was regarded as significant. The main outcome variables were LBW, APGAR score $<5$ at $1 \mathrm{~min}$, fetal anaemia and perinatal mortality. For each of these variables the odds ratio for maternal (and fetal) risk factors was estimated at 95 per cent confidence interval and multiple logistic regression analysis using the perinatal outcome as independent and the maternal factors as described above as independent variables were performed. In case of incomplete data, analyses were performed on patients with complete datasets, as reported.

\section{Ethics}

The study received ethical clearance from the Research Board at the Faculty of Medicine, University of Khartoum.

\section{RESULTS}

During the study period, there were 578 deliveries. Out of these, 24 were twins and 4 were triplets; hence 550 singleton deliveries were available for analysis.

\section{Demographic and clinical characteristics of the women}

The mean (SD) age of the mothers was 25.6 (6.4) years, 76 (14.6) \% of 522 women, had their age less then 20 years. The mean (SD) parity was $2.7(2.3)$ and $234(44.1 \%)$ of 531 women were primiparae. Around one fifth, 113 (21.4) of 529 women resided in the town and the remainder 416 (78.6) resided out side the town in the villages. Of the women, 186 (35.9\%), 183 (35.3\%) and 149 (28.8\%) were illiterate, had elementary and secondary or higher education respectively. The majority, 423 (82.0\%) of 516 women attended an antenatal care clinic for two or more occasion.

The mean (SD) of the BMI was 23.0 (4.6), 253 (55.5\%) of 456 women had their BMI below this mean.

The mean (SD) maternal haemoglobin was 11.5 (2.1) g/dl, 174 (34.5\%) of 505 women were anaemic; eight of these women had severe anaemia.

\section{Perinatal outcomes}

The mean (SD) of the cord haemoglobin was 13.9 (2.7) g/dl, 147 (29.0\%) of 507 babies had fetal anaemia. Three (1.4\%) positive $P$. falciparum malaria had been detected in the maternal peripheral placental and cord blood. 
Eighty (15.3) of 524 babies who were weighed had LBW, mean (SD) of the birth weight was 3053.6 (559.3) gm. One hundred -thirty four babies (\%) had APGAR score $<5$ at $1 \mathrm{~min}$. There were 46 (9.2\%) perinatal deaths.

\section{Risk factors for poor perinatal outcome}

Level of education, residence, antenatal care attendance had no association with any the perinatal outcome (data not shown). Maternal LBMI was significantly associated with $\mathrm{LBW}(\mathrm{OR}=2.3,95 \% \mathrm{Cl}=$ 1.0-5.1; $P=0.02)$, which was a risk factor for APGAR score $<5$ at $1 \mathrm{~min}(\mathrm{OR}=6.9,95 \% \mathrm{Cl}=2.8-16.8$; $P<0.000)$ and perinatal mortality $(\mathrm{OR}=309,95 \% \mathrm{Cl}=29.2-3271.1, P<0.00001)$. Table 1 and table 2.

Maternal anaemia was a risk factor for fetal anaemia $(O R=2.2,95 \% \mathrm{Cl}=1.2-3.9 ; \mathrm{P}=0.006)$ and APGAR score $<5$ at $1 \mathrm{~min}(\mathrm{OR}=0.48,95 \% \mathrm{Cl}=0.23-0.99 ; P=0.04)$. Table 1 and table 2 .

Table 1 factors associated with low birth weight and fetal anaemia in parturient women of eastern Sudan using multivariate analysis.

\begin{tabular}{lllllll}
\hline Variable & Low birth weight & Fetal anaemia & \\
& OR & $95 \% \mathrm{Cl}$ & $\mathrm{P}$ & OR & $95 \% \mathrm{Cl}$ & $P$ \\
\hline Teenager & 1.3 & $0.47-3.7$ & 0.5 & 0.45 & $0.16-1.2$ & 0.1 \\
Primiparae & 0.8 & $0.35-1.8$ & 0.6 & 1.1 & $0.64-2.0$ & 0.6 \\
Anaemia & 0.7 & $0.37-1.6$ & 0.5 & 2.2 & $1.2-3.9$ & 0.006 \\
Malaria & 0.6 & $0.28-1.3$ & 0.2 & 1.0 & $0.56-1.8$ & 0.94 \\
Low BMI & 2.3 & $1.0-5.1$ & 0.02 & 1.7 & $0.98-3.1$ & 0.05 \\
Low birth weight & - & - & - & 0.8 & $0.34-1.9$ & 0.6 \\
\hline
\end{tabular}

Table 2 factors associated with low APGAR score and perinatal death in parturient women of eastern Sudan using multivariate analysis.

\begin{tabular}{lllllll}
\hline Variable & & low APGAR & \multicolumn{3}{c}{ Perinatal death } \\
& OR & $95 \% \mathrm{Cl}$ & $\mathrm{P}$ & $\mathrm{OR}$ & $95 \% \mathrm{Cl}$ & $\mathrm{P}$ \\
\hline Teenager & 0.56 & $0.21-1.5$ & 0.25 & 0.9 & $0.18-4.4$ & 0.9 \\
Primiparae & 2.1 & $1.0-4.1$ & 0.03 & 1.1 & $0.36-3.7$ & 0.8 \\
Anaemia & 0.48 & $0.23-0.99$ & 0.04 & 1.0 & $0.35-2.9$ & 0.9 \\
Malaria & 0.88 & $0.46-1.6$ & 0.7 & 1.0 & $0.34-2.9$ & 0.9 \\
Low BMI & 1.0 & $0.55-1.8$ & 0.9 & 2.0 & $0.64-6.7$ & 0.2 \\
Low birth weight & 6.9 & $2.8-16.8$ & 0.000 & 4.8 & $1.6-14.2$ & 0.005 \\
Fetal anaemia & 0.96 & $0.45-2.0$ & 0.9 & 0.6 & $0.19-2.4$ & 0.5 \\
Low APGAR & - & - & - & 1.2 & $0.41-4.0$ & 0.6 \\
\hline
\end{tabular}

\section{DISCUSSION}

This hospital-based study in rural eastern Sudan has shown that low BMI had a very strong effect on LBW, which has a significant association on perinatal mortality. Maternal anaemia was a risk factor for fetal anaemia and low APGAR score. Maternal socio-demographic (with exception of primiparae) factors and placental malaria on the other hand, were not associated with any of the perinatal outcomes in this study. Actually we planned to conduct this study based on our previous observations on malaria and anemia among pregnant women and we aimed to explore their influence on perinatal outcome. Surprisingly no association between malaria and perinatal outcome was detected and this remain to be investigated in the future. The prevalence of malaria among these parturient women was unexpectedly low in comparison with our previous records (Adam et al., 2005) among the antenatal attendants in the same hospital; this could be one of the explanations. The other possibility is that, the epidemiology of the malaria and its related anaemia might have been interrupted by the recent vigorous - and hopefully sustainable- implementation of the preventive measures (bed nets and prophylactic sulphadoxine-pyremethamine) in the area (Adam et al., 2007). 
Malaria during pregnancy can have serious consequences for the newborn baby- regardless of the level of malaria transmission - and constant association between placental infection and low birth weight had been reported in central Sudan and in the neighboring Ethiopia (Taha et al., 1993; Newman et al., 2003). Furthermore, $P$. falciparum malaria had been reported to be association with poor perinatal outcome (especially the severe form) in eastern central Sudan (Adam et al., 2004). However, few studies have revealed no association between malaria and LBW (Sule-Odu et al., 2002; Weiner et al., 2003). The study was conducted at the labour ward in the main hospital. The sample was not representative to whole community and allows the analysis in relation to specific risk factors for those delivering in the hospital only.

In this study the maternal anaemia was associated with poor perinatal outcome mainly low APGAR score and fetal anaemia. This goes with the previous observations from other African countries (Brabin and Piper, 1997; Malhotra etal., 2002). Levy and others had reported an association between anaemia, LBW and preterm labour (Levy et al., 2005). Comparison between these two studies should be taken cautiously because unlike our current study the other one considered the level of $10 \mathrm{gm} / \mathrm{dl}$ as a cut off point for maternal anaemia. Recently it had been reported that, maternal anemia was the main risk factor for fetal anaemia (Brabin, et al., 2004). The iron status of babies born to iron-deficient mothers is compromised and fetal iron stores are reduced in LBW and preterm infants (Ahmad et al., 1983; Siimes et al., 1985).

In the current study, around half of the women had low BMI (< the mean) and these women were at double risk of delivering LBW infant. Low BMI was associated with poor perinatal outcome in other setting (Osman et al., 2001; Lasker et al., 2005). We feel that, the issue low BMI together with other anthropometric measures and nutrition and their influence on maternal and perinatal outcome needs to be investigated in this area in more depth in the near future.

An important point in this study is that, primiparae were at higher risk for low APGAR score infants $(\mathrm{OR}, 2.1,95 \% \mathrm{Cl}=1.0-4.1)$. This might be a signal to another important but different public health issue, the labour and its management in the area and the association between labour and the perinatal outcome. The current study was designed to explore the influence of malaria and anaemia on perinatal outcome mainly, hence could not investigate the influence on labour management on perinatal outcome. In neighboring Kenya, where the management of labor was addressed directly, the association with perinatal outcome was significant to an extent of masking other important confounding factors such as malaria and HIV (Weiner et al., 2003).

Importantly, HIV which has a significant impact on maternal and perinatal outcome in Africa was not investigated in the current study. According to our previous records, HIV has a low prevalence (1\%) among pregnant Sudanese and Sudanese women had low intake of HIV counseling and testing (Gassmelseed et al., 2006; Mahmoud et al., 2007). These points need to be mentioned when comparing these data with that data from other African countries.

\section{CONCLUSION}

Thus, more work is needed in the area of nutritional status, anthropometrics measures, labour and its management in the area. Malaria, anaemia perinatal outcome need to be explored in more depth. 


\section{REFERENCES}

Adam I, Ali D M, Elbashir MI. (2004). Manifestations of falciparum malaria among pregnant of Eastern Sudan. Saudi Med J, 25: 947-951.

Adam I, Khamis AH, Elbashir M. (2005). Prevalence and risk factors for anaemia in pregnant women of eastern Sudan. Trans R Soc Trop Med Hyg, 90 :739-743.

Adam I, Omer EM, Salih A, Khamis, Malik EM. (2007). Perceptions of the causes of malaria and of its complications, treatment and prevention among midwives and pregnant women of Eastern Sudan. Journal of Public Health, in press.

Ahmad SH, Amir M, Ansari Z, Ahmed KN. (1983). Influence of maternal iron deficiency anemia on the fetal total body iron. Indian Pediatr, 20: 643-646.

Brabin B, Piper C. (1997). Anaemia and malaria attributable low birth weight in two populations in Papua New Guinea. Ann Hum Biol, 24: 547-555

Brabin BJ, Kalanda BF, Verhoeff FH, Chimsuku LH, Broadhead RL. (2004). Risk factors for fetal anaemia in a malarious area of Malawi. Ann Trop Paediatr, 24: 311-321.

Bulmer JN, Rasheed FN, Francis N, Morrison L, Greenwood BM. (1993). Placental malaria. I. Pathological classification. Histopathology, 22: 211-218.

Gassmelseed DE, Nasr AM, Homeida SM, Elsheikh MA, Adam I. (2006). Prevalence of HIV infection among pregnant women of the central Sudan. J Med Virol, 78:1269-1270.

Lasker JN, Coyle B, Li K, Ortynsky M. (2005). Assessment of risk factors for low birth weight deliveries. Health Care Women Int, 26: 262-280.

le Cessie S, Verhoeff FH, Mengistie G, Kazembe P, Broadhead R, Brabin BJ le Cessie S, Verhoeff FH. (2002). Changes in haemoglobin levels in infants in Malawi: effect of low birth weight and fetal anaemia. Arch Dis Child Fetal Neonatal Ed, 86:182-187.

Levy A, Fraser D, Katz M,Mazor M, Sheiner E. (2005). Maternal anemia during pregnancy is an independent risk factor for low birthweight and preterm delivery. Eur J Obstet Gynecol Reprod Biol, 122:182-186.

Mahmoud MM, Naser AM, Gassmelseed DA, Abdalelhafiz MA, Elsheikh MA, Adam I. (2007). Attitude towards HIV and HIV voluntary counselling and testing among pregnant Sudanese women. J Med Virol, 79: 469-473

Malhotra M, Sharma JB, Batra S, Sharma S, Murthy NS, Arora R. (2002). Maternal and perinatal outcome in varying degrees of anemia. Intern J Gynecol Obstet; 79: 93-100.

Newman RD, Hailemariam A, Jimma D, Degefie A, Kebede D, Rietveld AC, Nahlen B L, Barnwell JW, Steketee RW, Parise ME. (2003). Burden of malaria during pregnancy in areas of stable and unstable transmission in Ethiopia during a nonepidemic year. J Infect Dis, 187: 1765-1772.

Osman NB, Challis K, Cotiro M, Nordahl G, Bergstrom S. (2001). Perinatal outcome in an obstetric cohort of Mozambican women. J Trop Pediatr, 47: 30-38.

Saving Newborn Lives. (2001). The state of the world's newborns: a report from saving Newborn Lives. Washington DC: Save the Children;:14.

Siimes, MA. Iron nutrition in low - birthweight infants. In: Stekel A, ed. Iron deficiency in infancy and childhood. New York: Nestle Nutrition Workshops Series, vol 4, 1985.

Sule-Odu AO, Ogunledun A, Olatunji AO. (2002). Impact of asymptomatic maternal malaria parasitaemia at parturition on perinatal outcome. J Obstet Gynaecol, 22: 25-8.

Taha ET, Ronald HG, Abdalla AM. (1993). Malaria and low birth weight in central Sudan. Am J Epidemiol, 138, 315-325.

United Nations, General Assembly, 56th session. Road map towards the implementation of the United Nations Millenium Declaration: report of the Secretary-General. New York: United Nations; 2001.

Verhoeff FH, Le Cessie S, Kalanda BF, Kazembe PN, Broadhead RL, Brabin BJ. (2004). Post-neonatal infant mortality in Malawi: the importance of maternal health. Ann Trop Paediatr, 24:161-169 
Weiner R, Ronsmans C, Dorman E, Jilo H, Muhoro A, Shulman C. (2003). Labour complications remain the most important risk factors for perinatal mortality in rural Kenya. Bull World Health Organ, 81: 561-566. 


\title{
Chapter 7
}

\section{Malaria susceptibility and cortisol levels in}

\author{
pregnant women of eastern Sudan
}

Published in apart as: Adam I, Nour BY, Ibrahim EY, Almahi W A, Omer EM, Ali NY. (2007). Cortisol and susceptibility to malaria in pregnant women in an area of unstable malaria transmission in eastern Sudan, Intern J Gynecol Obstet, 98: 260-261. 


\section{ABSTRACT}

\section{Background}

While much data exists on pathogenesis of malaria during pregnancy in areas of intense malaria transmission, probably no or little data are available in the areas of unstable malaria transmission.

\section{Aims}

The study was conducted to investigate the role of cortisol and prolactin in the pathogenesis of $P$. falciparum malaria during pregnancy.

\section{Methods}

The concentrations of both cortisol and prolactin were measured in sera from two groups of pregnant women in eastern Sudan. One group consisted of 50 pregnant women (18 primigravidae and 32 multigravidae) presenting with uncomplicated $P$. falciparum malaria and the other group comprised 49 healthy volunteer pregnant women (13 primigravidae and 36 multigravidae).

\section{Results}

There was no significant difference in concentration of total cortisol in pregnant women with malaria in comparison with the control group, and this is true for both primigravidae and multigravidae. In women with uncomplicated malaria cortisol concentration did not differ significantly between primigravidae and multigravidae. Cortisol was not correlated with the gravidity, gestational age or initial temperature, but positive correlation was observed in cortisol and parasite count. The total serum prolactin was not significantly different between the infected and non-infected group for both primigravidae and multigravidae.

\section{Conclusion}

Although, this was small sample sized study, cortisol and prolactin levels were not significantly different between the infected and non-infected women, even in primigravidae and multigravidae. 


\section{BACKGROUND}

It has been estimated that, $40 \%$ of the pregnant women are exposed to malaria infection during pregnancy and most of this burden is in Sub Saharan Africa where $90 \%$ of the global malaria burden occurs (Steketee et al., 2001). Malaria during pregnancy poses a substantial risk to the mother, her fetus, and the neonate; the infection contributes to maternal anemia, low birth weight infants, and infant mortality (Cot and Deloron, 2003). Malaria is the major health problem in the Sudan and it has been reported that, pregnant Sudanese women are more attractive to the main malaria vector and more susceptible to malaria than their non-pregnant counterparts (Elghazali et al., 2003; Himeidan et al., 2004; Malik and Khalafalla, 2004). It is associated with maternal anaemia, low birth weight infants and it is the main cause of maternal mortality (Dafallah,et al., 2003; Adam et al., 2005a; Adam et al., 2005b).

Understanding the pathogenesis of malaria during pregnancy is fundamental- yet not completely understood- for the understanding of the disease as whole and may be essential for the development of the future vaccine for these vulnerable groups. There are many hypotheses that could explain susceptibility of pregnant women to the malaria. Indications were obtained that higher cortisol levels cause loss of malaria immunity during pregnancy (Vleugels et al., 1987; Vleugels et al., 1989; Bouyou-Akotet et al., 2005). These reports are compatible with recent findings of interactions between natural killer cells, cortisol and prolactin in malaria during pregnancy (Mavoungou, 2006). The present work was conducted to investigate the serum cortisol and prolactin among pregnant women of eastern Sudan. The area is characterized by unstable malaria (Himeidan et al., 2005a; Himeidan et al., 2005b). Malaria during pregnancy is big burden in the area and pregnant women are more susceptible to falciparum malaria irrespective to their age and parity (Adam et al., 2005a).

\section{MATERIALS AND METHODS}

The study was conducted in New Half, eastern Sudan during the period of September-November 2006, where consecutive pregnant women presented (before the midday) with uncomplicated $P$. falciparum malaria were approached to participate in the study. Healthy pregnant volunteers that matched for age, parity and gestational age were taken as control. After an informed consent was taken, pre-tested questionnaires were filled to gather the socio-demographic charters, the basic medical and obstetrical history (including the parity and gestational age). The women were examined clinically, where their temperature was taken and the fundal level was determined. Blood films were prepared, stained with Giemsa and 100x oil immersion fields were examined. The parasite density was counted against 200 leucocytes, assuming 6000 leucocytes/ $\mu$ l. All the slides were double-checked blindly and only considered negative if no parasites were detected in 100 oil immersion fields. Then $5 \mathrm{ml}$ of blood was taken-after haemoglobin level was determined centrifuged immediately and kept at $-200 \mathrm{C}$ till analyzed by radioimmunoassay gamma counter (Riostad, Germany). IRMA KIT (RK-780MACE040501) and RIA KIT (RK-240MACED040501) of IZOTOP (Budapest) were used for analysis of prolactin and cortisol levels respectively. The entire samples were analyzed by the same person, who is blind about the clinical findings of the patients.

\section{Ethical clearance}

The study received ethical clearance from the Research Board at the Faculty of Medicine, University of Khartoum, Sudan.

\section{Statistical analysis}

Data were entered into a computer database and SPSS software (SPSS Inc., Chicago, IL, USA) was used for statistical analysis. The means (age, weight, temperature, and hemoglobin) were calculated for all the patients and were compared between the patients in the two arms of the study subgroups using student t-test, when the data was normally distributed and by Mann- 
Whitney test if the data was not normally distributed. The mean (SD) of cortisol and prolactin levels were calculated and compared between the patients in the two arm of the study groups and subgroups using student t-test. Correlations between parasitemia, temperature, gestational age, gravidity and cortisol levels (and prolactin) were determined. A $P$-value 0.05 was considered to be significant.

\section{RESULTS}

During the study period, 50 pregnant women presented with uncomplicated $P$. falciparum malaria. Forty-nine healthy pregnant women were taken as control. With exception of haemoglobin, the two groups were well matched and the there was no difference between them, table1.

Table 1 comparison of different variable between the pregnant women with uncomplicated falciparum malaria and the controls.

\begin{tabular}{llllll}
\hline Variable & \multicolumn{7}{c}{ Infected women } & & control & $P$ Value \\
& \multicolumn{7}{l}{} & & \\
\hline Age in years & 26.0 & $(7.1)$ & 26.1 & $(6.7)$ & 0.925 \\
Gravidity & 3.5 & $(2.5)$ & 2.8 & $(2.0)$ & 0.18 \\
Weight, Kg & 58.7 & $(12.0)$ & 57.5 & $(12.2)$ & 0.632 \\
Gestational age, weeks & 24.6 & $(8.5)$ & 26.6 & $(6.2)$ & 0.185 \\
Haemoglobin, g/dl & 9.1 & $(1.3)$ & 9.9 & $(.8)$ & 0.001 \\
\hline
\end{tabular}

The mean (SD) of the total cortisol level was not significantly different between women with uncomplicated $P$. falciparum malaria and the control; $646.3(1512.9) \mathrm{ng} / \mathrm{ml}$ vs. 434.7(173.08) ng/ml, $P=0.333$. This is also true in infected primigravidae (12) and non-infected primigravidae (18); $474.0(151.04) \mathrm{ng} / \mathrm{ml}$ vs. $463.6(197.9) \mathrm{ng} / \mathrm{ml}, P=0.897$ or multigravidae in both groups, table 2. In all the patients (infected and non-infected), there was no significant difference in cortisol level between the primigravidae (31) and multigravidae (68); $469.6(169.1)$ vs $574.3(1302.2) \mathrm{ng} / \mathrm{ml}, P=$ 0.657. In women with uncomplicated $P$. falciparum malaria, the mean (SD) of the total cortisol levels were not different in primigravidae (12) and multigravidae (38), table 2.

Table 2 showing mean (SD) of the cortisol level in the different subgroups of pregnant women of eastern Sudan.

\begin{tabular}{llllllll}
\hline & \multicolumn{2}{c}{ Total } & \multicolumn{2}{c}{ Primigravidae } & Multigravidae & $P$ value \\
\hline Infected women & 646.3 & $(1512.9)$ & 474.0 & $(151.04)$ & 743.3 & $(1891.7)$ & 0.097 \\
Control & 434.7 & $(173.08)$ & 463.6 & $(197.9)$ & 424.2 & $(165.0)$ & 0.487 \\
$P$ value & 0.333 & & 0.897 & & 0.317 & & \\
\hline
\end{tabular}

In infected group of women; a positive correlation was observed in cortisol level and parasite count ( $r=0.332, P=0.02$ ), but there were no significant correlations between the total cortisol levels and temperature $(r=0.069, P=0.64)$, gravidity $(r=0.174, P=0.233)$, or the gestational age $(r=0.087, P$ $=0.552$ ). Likewise, there was no significant difference in prolactin levels between the infected and non infected groups, or subgroups and primigravidae (31) and multigravidae (68), 8445.9 (5648.8) mu/lvs. 7103 (5402.6) $\mathrm{mu} / \mathrm{l}, P=0.261$, table 3.

In infected group of women: a positive correlation was observed in prolactin levels and the gestational age $(\mathrm{r}=0.472, P=0.001)$, but there were no significant correlations between the total prolactin levels and temperature $(r=0.005, P=0.971)$, parasite count $(r=0.126, P=0.390)$, or gravidity $(r=0.150, P=0.303)$. 
Table 3 showing mean (SD) of the prolactin level in the different subgroups of pregnant women of eastern Sudan

\begin{tabular}{llllllll}
\hline & Total & & \multicolumn{2}{c}{ Primigravidae } & \multicolumn{2}{c}{ Multigravidae } & \multicolumn{2}{c}{$P$ value } \\
\hline Infected women & 8123.9 & $(5310.9)$ & 9788.2 & $(5182.7)$ & 7187.2 & $(5228.8)$ & 0.551 \\
Control & 6911.2 & $(5650.9)$ & 6587.3 & $(5939.2)$ & 7028.2 & $(5625.4)$ & 0.812 \\
$P$ value & 0.274 & & 0.121 & & 0.904 & & \\
\hline
\end{tabular}

\section{DISCUSSION}

The study showed that, the cortisol levels were not significantly different between pregnant women infected with $P$. falciparum malaria and the controls. This contradicts previous findings, where cortisol level was significantly higher in pregnant women infected with $P$. falciparum malaria in comparison to the control group (Vleugels et al., 1987; Vleugels et al., 1989) and also in nonpregnant populations with uncomplicated $P$. falciparum malaria than in the control (Shwe et al., 1998). The significantly higher level of serum cortisol in the infected patients previously reported indicated and intact hypothalamous/pituitary/ adrenal axis in these reports. Activation of this axis in malaria might be due to release of cytokines and/ or results of stress generated by the disease; it had been observed earlier that cytokines level was associated with basal and peak levels of ACTH (Wilson et al., 2001). Interestingly in this study, the serum cortisol levels were not significantly different between primigravidae and multigravidae infected with uncomplicated $P$. falciparum malaria. We have recently found that, pregnant Sudanese women in the same hospital are at risk for $P$.falciparum malaria irrespective to their age or parity (Adam et al., 2005a). However, significantly higher cortisol levels were found in primigravidae compared with multigravidae (Vleugels et al., 1986).

In the present study, cortisol was not correlated with the gravidity, gestational age or initial temperature, but a positive correlation was observed between cortisol and parasite count. This goes with previous findings reporting, a positive correlation between cortisol levels and parasite load in primigravidae infected with P. falciparum malaria (Vleugels et al., 1989). Yet, recently Libonati and colleagues had found no correlation between cortisol and the parasite count in nonpregnant population infected with falciparum malaria (Libonati et al., 2006). This is expected as pregnancy is a unique situation where the immunomodulation is mediated by cortisol and other steroidal hormones as estrogen and progesterone (Roberts et al., 1996).

Even in healthy pregnant women, the serum concentration of total cortisol increased linearly with progression of amenorrhea. Significantly higher cortisol levels were found in nulliparas compared to multiparas and independent of amenorrhea (Vleugels et al., 1986). Recently, Bouyou-Akotet and colleagues observed that, cortisol concentrations increased with gestational age (Bouyou-Akotet et al., 2005). This study showed that, prolactin was not significantly different between the infected women and control. However, a positive correlation was observed between prolactin levels and the gestational age. This is in agreement with the previous study (Bouyou-Akotet et al., 2005). The Interactions between natural killer cells, cortisol and prolactin in malaria during pregnancy were recently discussed (Mavoungou , 2006).

The present study has many limitations; it is small sample sized, cortisol and prolactin levels were measured from different patients only once. Ideally these hormones need to be analyzed in the same pregnant women at different intervals and at different gestational age and according to the parasitemia. However, our findings are totally different from the previous reports. So larger studies in this area and other areas of unstable malaria transmission are recommended. 


\section{ACKNOWLEDGMENTS}

We wish to thank all the patients for their excellent co-operation and we are very grateful to the local health authority in Kassala State, Sudan and to the entire Staff of New Halfa teaching hospital. Thanks are also extended to Mr. Abdalla A. Hufazalla for his excellent technical assistance. 


\section{REFERENCES}

Adam I, Khamis AH, Elbashir MI. (2005a). Prevalence and risk factors for malaria in pregnant women of eastern Sudan. Malar J, 4: 8.

Adam I, Khamis AH, Elbashir MI. (2005b). Prevalence and risk factors for anaemia in pregnant women of eastern Sudan. Trans R Soc Trop Med Hyg, 90: 739-743.

Bouyou-Akotet MK, Adegnika AA, Agnandji ST, Ngou-Milama E, Kombila M, Kremsner PG, Mavoungou E. (2005). Cortisol and susceptibility to malaria during pregnancy. Microbes Infect, 7: 1217-1223.

Cot M, Deloron P. (2003). Malaria during pregnancy: consequences and interventional perspectives. Med Trop, 63: 369-380.

Dafallah SE, EL-Agib FH, Bushra GO. (2003). Maternal mortality in a teaching hospital in Sudan. Saudi Med J, 24: 369-373.

EIGhazali G, Adam I, Hamad AA, Elbashir M I. (2003). Malaria and pregnancy in an area of unstable transmission in eastern Sudan. East Mediterr Health J, 9: 571-580

Himiedan YE, Elbashir MI, Adam I. (2004). Attractiveness of pregnant Sudanese women to malarial vector-Anopheles arabiensis, Ann Trop Med Parasitol, 98: 631-633.

Himeidan YE, Malik EM, Adam I. (2005). Epidemiology and seasonal pattern of malaria in an irrigated area of eastern Sudan. Am J Inf Dis, 1: 75-78.

Himeidan YE, Elbashir MI, El-Rayah el-A, Adam I. (2005). Epidemiology of malaria in New Halfa, an irrigated area in eastern Sudan. East Mediterr Health J, 11: 499-504.

Mavoungou E. (2006). Interactions between natural killer cells, cortisol and prolactin in malaria during pregnancy. Clin Med Res, 4: 33-41.

Libonati RM, de Mendonca BB, Maues JA, Quaresma JA, de Souza JM. (2006). Some aspects of the behavior of the hypothalamus-pituitary-adrenal axis in patients with uncomplicated Plasmodium falciparum malaria: Cortisol and dehydro-epiandrosterone levels. Acta Trop, 98: 270-276.

Malik EM, Khalafalla OM. (2004). Malaria in Sudan: past, present and the future. Gezira Journal of Health Sciences 1, (suppl): 47-51.

Roberts CW, Satoskar A, Alexender J. (1996). Sex steroids, pregnancy associated hormones and immunity to parasite infections. Parasitology Today, 12: 382-388.

Shwe T, Khin M, Min H, Hla KK, Win YY, Htwe K, Thu TM. (1998). Serum cortisol levels in patients with uncomplicated and cerebral malaria. Southeast Asian J Trop Med Public Health, 29: 4649.

Steketee R W, Nahlen BL, Parise MF, Menendez C. ( 2001). The burden of malaria in pregnancy in malaria-endemic areas. Am J Trop Med Hyg, 64 (Suppl): 28-35.

Vleugels MP, Eling WM, Rolland R, de Graaf R. (1986). Cortisol levels in human pregnancy in relation to parity and age. Am J Obstet Gynecol, 155:118-121

Vleugels MP, Eling WM, Rolland R, de Graaf R. (1987). Cortisol and loss of malaria immunity in human pregnancy. BrJ Obstet Gynaecol, 94: 758-764.

Vleugels MP, Brabin B, Eling WM, de Graaf R. (1989). Cortisol and Plasmodium falciparum infection in pregnant women in Kenya. Trans $R$ Soc Trop Med Hyg, 83: 173-177.

Wilson M, Davis TM, Binh TQ, Long TT, Danh PT, Robertson K. ( 2001). Pituitary-adrenal function in uncomplicated falciparum malaria. Southeast Asian J Trop Med Public Health, 32: 689-695. 



\title{
Chapter 8
}

Perceptions of the causes of malaria and of its complications, treatment and prevention among midwives and pregnant

\author{
women of eastern Sudan
}

Published as: Adam I, Omer EM, Salih A, Khamis Malik. EM. (2007). Perceptions of the causes of malaria and of its complications, treatment and prevention among midwives and pregnant women of Eastern Sudan. Journal of Public Health, online. 


\section{ABSTRACT}

\section{Background}

Malaria infection during pregnancy is a big burden in Sudan and has many adverse effects on both mother and fetus. There are no data concerning the local socio-cultural knowledge on malaria, its complications and prevention during pregnancy.

\section{Aim}

This study was conducted to assess the perceptions of the causes of malaria, its complications, treatment and prevention among midwives and pregnant women of eastern Sudan, so as to provide policy makers and malaria programme managers with information needed to improve the design of malaria control.

\section{Methods}

Eighty-seven midwives and 168 pregnant women were interviewed.

\section{Results}

More than three quarters $(78.2 \%)$ of the midwives and $(82.7 \%)$ pregnant women perceived that mosquitoes were the transmitters of malaria. The coverage of ITNs was $65.5 \%$ among the interviewed pregnant women.

There was poor knowledge about the complications of malaria during pregnancy, and the effect of malaria treatment on the fetus among the interviewed midwives and pregnant women. More than sixty percent, $59(67.8 \%)$ of the midwives and almost all the pregnant women $162(96.4 \%)$ had no knowledge towards the IPT.

\section{Conclusion}

Thus, inspite of good knowledge towards symptoms of malaria during pregnancy, there was lack of perception on the prevention and the safety of intermittent preventive treatment. 


\section{BACKGROUND}

It has been estimated that $40 \%$ of the pregnant women are exposed to malaria infection during pregnancy and most of this burden is in Sub- Saharan Africa, where $90 \%$ of the global malaria burden occurs (Steketee et al., 2001). Malaria during pregnancy poses a substantial risk to the mother, her fetus, and the neonate. Malaria infection contributes to maternal anemia, low birth weight, and infant mortality (Cot and Deloron, 2003). Malaria is a major health problem in Sudan (Malik and Khalafalla, 2004). It has been reported that pregnant women are more attractive to the main malaria vector and more susceptible to malaria than their non-pregnant counterparts (ElGhazali et al., 2003; Himeidan et al., 2004; Adam et al., 2005a). In Sudan: malaria during pregnancy has been reported to be associated with maternal anaemia, low birth weight infants and as the main cause of maternal mortality (Dafallah et al, 2004; Adam et al., 2005b).

Sleeping under an insecticide-treated bednet (ITN) can reduce the risk of a pregnant woman being infected with malaria and reduce the risks of maternal anaemia and low birth weight (Ter Kuile et al., 2003). Another preventive measure against the adverse effects of malaria during pregnancy is intermittent preventive treatment (IPT) with two doses of sulphadoxine-pyrimethamine (SP). IPT with SP has been reported to reduce low birth weight deliveries in malarious areas (Parise et al., 1998; Verhoeff et al., 1998).

On 25 April 2000, 44 African heads of state and government delegations adopted the Abuja Declaration on Roll Back Malaria in Africa (AFRO, 2002). Among other goals, they pledged that by 2005, 'at least $60 \%$ of all pregnant women who are at risk of malaria, especially those in their first pregnancies, will have access to chemoprophylaxis or presumptive intermittent treatment. Thus far, this promising intervention, named IPT has not been widely implemented in malaria-endemic areas of Africa. Following this recommendation, many researchers and the Sudanese Federal ministry of health recommended IPT and ITN for pregnant women in areas of stable malaria transmission and irrigated areas-the study area (Adam et al., 2005a; b). Only $13 \%$ and $1.8 \%$ of pregnant Sudanese women have used ITNs and IPT respectively (Malik, unpublished), thus far from the recommendations.

It has been shown that acceptance of IPT and ITN depends on cultural, behavioural and demographic factors (Govere et al., 2000). The perception and attitude towards malaria and its prevention during pregnancy has been extensively studied in other African countries with stable malaria transmission (Launiala et al., 2006; Mbonye et al., 2006a; Mbonye et al., 2006b) The aim of this study was to explore knowledge, perception, beliefs and practices associated with malaria, its complication, treatment and prevention among midwives and pregnant women of eastern Sudan since no proper published data exist.

\section{METHODS}

The study was conducted during July 2006 in New Halfa area, eastern Sudan which is characterized by unstable malaria transmission (Himeidan et al., 2005). After obtaining an informed consent, all the midwives in the area and all the pregnant women in 21 villages- out of 176 villages- were interviewed. Pre-tested structured questionnaires were administered to collect the sociodemographic characteristics including residence, age, parity, gestational age and the level of education (Govere et al., 2000). Then the interviews began with broad unstructured and nondirective questions about pregnancy, delivery and health of pregnant women and gradually focused towards malaria during pregnancy, its causes, symptoms, complications (miscarriage, preterm labour, anemia and maternal death), treatment seeking behaviors and the safety of antimalarials. Special questions were raised regarding their perception of the preventive measures (ITN and IPT) during pregnancy and the women's willingness to use these preventive packages in the future. 


\section{Ethical clearance}

The study received ethical clearance from the Sudanese National Committee of the Federal ministry of Health.

\section{RESULTS}

During the study period, 87 midwives and 168 pregnant women were interviewed. The mean (SD) of the age and parity of the pregnant women were 25.6 (9.4) years and 2.5 (2.8) respectively. More than three quarters, $68(78.2 \%)$ and $139(82.7 \%)$ of the midwives and pregnant women respectively had knowledge that mosquitoes were the cause of malaria. While, $10(6.0 \%)$ of the pregnant women did not know the cause of malaria and 5 (3.0\%) of them mentioned stagnant water as the cause of malaria, table 1 . Above ninety percent of the midwives, $83(95.4 \%)$ and pregnant women, $163(97.0 \%)$ mentioned two or more symptoms of malaria. The majority, 137 (81.5\%) of the pregnant women would go to the doctor and $15(8.9 \%)$ would go to the midwife if they felt unwell or had symptoms suggestive of malaria, while the rest $(9.5 \%)$ would take medicine by themselves or just take good food.

Anaemia was mentioned as a complication of malaria during pregnancy by $31(35.6 \%)$ and $87(51.8 \%)$ of the midwives and the pregnant women respectively. More than one quarter, 27 $(31.0 \%)$ and $15(8.9 \%)$ of the midwives and pregnant women respectively mentioned miscarriage as a complication of malaria. Low birth weight as a complication of malaria was mentioned by 24 $(27.6 \%)$ and $11(6.5 \%)$ of the midwives and pregnant women respectively, table1. More than one quarter, 48 (28.6\%) of the pregnant women did not mention any complication of malaria on pregnancy. Around one fifth, $19(21.8 \%)$ and $65(38.7 \%)$ of the interviewed midwives and pregnant women mentioned that malaria treatment is harmful for the fetus. More than two fifth, 73 (43. 5\%) of the pregnant women were not using bed nets; either because it was not available (21), hot (7), nasty (1), unpleasant (18), restrict their movement (13), they were lazy (13) or it would not be protective (1). Around two thirds 95 (65.5\%) of the pregnant women using nets, did not use it last night.

More than sixty percent, $59(67.8 \%)$ of the midwives and almost all the pregnant women 162 (96.4\%) had no knowledge towards the IPT. More than one third, $29(33.3 \%)$ and $14(8.3 \%)$ of the interviewed midwives and pregnant women mentioned that SP was harmful and unsafe to be used during pregnancy.

Table 1 component of the knowledge score among interviewed midwives and pregnant Sudanese women

\begin{tabular}{lllll}
\hline Statement & \multicolumn{2}{l}{$\begin{array}{l}\text { Number (\%) of the midwives } \\
\text { Total number }=87\end{array}$} & $\begin{array}{l}\text { Number (\%) of the pregnant women } \\
\text { Total number = 168 }\end{array}$ \\
\hline $\begin{array}{c}\text { Malaria transmission } \\
\text { Mosquitoes }\end{array}$ & 68 & $(78.2 \%)$ & 139 & $(82.7 \%)$ \\
$\quad \begin{array}{l}\text { Flies } \\
\text { Stagnant water }\end{array}$ & 7 & $(8)$ & 14 & $(8.3)$ \\
No cause & 6 & $(7)$ & 5 & $(3.0 \%)$ \\
& & $(7)$ & 10 & $(6.0 \%)$ \\
Consequences & & & & \\
Maternal anemia & 31 & $(35.6)$ & 87 & $(51.8)$ \\
Low birth weight & 24 & $(27.6)$ & 11 & $(6.5)$ \\
Miscarriage & 27 & $(31)$ & 15 & $(8.9)$ \\
Others & 3 & $(3.4)$ & 7 & $(4.1)$ \\
No answer & 2 & $(2.3)$ & 48 & $(28.6)$ \\
\hline
\end{tabular}




\section{DISCUSSION}

Probably, this is the first published data investigating the perceptions of the causes of malaria and of its complications, treatment and prevention among midwives and pregnant women of eastern Sudan. The study showed that, the interviewed midwives and pregnant women had good knowledge towards malaria symptoms; perceived mosquitoes as the cause of malaria and the coverage of ITNs was $65.5 \%$. The main reasons for not using ITNs were; not available, hot, smelly, and unpleasant and restrict the movement. Previously, women of the central Sudan were less likely to be involved in drying mosquito breeding sites and spraying activities of insecticides because of fear of allergy and bad odour of these materials (A/Rahman et al., 1996). In the neighboring Uganda, mosquitoes were perceived as the cause of malaria but as the same time use of ITNs was only $26 \%$. People who did not use ITNs cited discomfort due to heat and humidity; and the high cost of ITNs as reasons for non-use (Nuwaha, 2002; Mbonye et al., 2006a). In Kenya, although malaria was perceived to be an important disease, ITNs were believed to be partially beneficial because of the perception that malaria has multiple causes and the belief that chemicals used to treat ITNs were associated with family planning (Alaii et al., 2003). However, thirty-six percent of Malawian women did not know what causes malaria and ninety-five percent of them mentioned one or more symptoms of malaria (Launiala et al., 2006).

Our study showed that, anaemia, miscarriage and low birth weight as complications of malaria during pregnancy were mentioned by $51.8 \%, 8.9 \%$ and $6.5 \%$ of the pregnant women respectively, and around one quarter (28.6\%) of the pregnant women did not mention any complication of malaria during pregnancy. Recently Mbonye and colleagues (Mbonye et al., 2006b), reported poor knowledge towards the complications of malaria during pregnancy e.g. anaemia and low birth weight.

Substantial concern about the use of IPT during pregnancy was expressed by the midwives and pregnant women in this study and the majority of the midwives and almost all the pregnant women (98\%) had no knowledge towards the IPT. More than one third of the interviewed midwives and pregnant women mentioned that SP is harmful and unsafe to be used during pregnancy. Although, the majority of women considered antimalarials to be less harmful than effects of malaria itself on pregnancy; they didn't realize the role of malaria chemoprophylaxis during pregnancy. Previously, a negative perception towards SP usage during pregnancy has been reported and SP has been believed to be a strong drug and might lead to abortion and congenital malformations (Mbonye et al., 2006c).

Thus, more effort is needed through different programmes (health education, training and teaching) urgently to raise the coverage of these preventive measures among the vulnerable group of pregnant women.

\section{ACKNOWLEDGMENTS}

This investigation received technical and financial support from the joint WHO Eastern Mediterranean Region (EMRO), Division of communicable Diseases (DCD) and the WHO Special Programme for Research and Training in Tropical Diseases (TDR): The EMRO/TDR Small Grants Scheme for Operational Research in Tropical and other Communicable Diseases." 


\section{REFERENCES}

Adam I, Khamis AH, Elbashir MI. (2005a). Prevalence and risk factors for malaria in pregnant women of eastern Sudan. Malaria J, 4, (1) 8.

Adam I, Khamis AH, Elbashir MI. (2005b). Prevalence and risk factors for anaemia in pregnant women of eastern Sudan. Trans R Soc Trop Med Hyg, 90: 739-743.

AFRO. (2002). Strategic framework for malaria control during pregnancy in the WHO African region, November 1.

Alaii JA, van den Borne HW, Kachur SP, Shelley K, Mwenesi H, Vulule JM, Hawley WA, Nahlen BL, Phillips-Howard PA. (2003). Community reactions to the introduction of permethrin-treated bed nets for malaria control during a randomized controlled trial in western Kenya. Am J Trop Med Hyg, 68 (4 Suppl):128-136.

A/Rahman SH, Mohamedani AA, Mirgani EM, Ibrahim AM. (1996). Gender aspects and women's participation in the control and management of malaria in central Sudan. Soc Sci Med, 42:1433-1446.

Cot M, Deloron P. (2003). Malaria during pregnancy: consequences and interventional perspectives. Med Trop, 63:369-380.

Dafallah SE, EL-Agib FH, Bushra GO. (2003). Maternal mortality in a teaching hospital in Sudan. Saudi Med J, 24: 369-373.

EIGhazali G, Adam I, Hamad AA, Elbashir MI. (2003). Malaria and pregnancy in an area of unstable transmission in eastern Sudan. East Mediterr Health J, 9: 571-580.

Govere J, Durrheim D, la Grange K, Mabuza A, Booman M. (2000). Community knowledge and perceptions about malaria and practices influencing malaria control in Mpumalanga Province, South Africa. S Afr Med J, 90: 611-616.

Himiedan YE, Elbashir MI, Adam I. (2004). Attractiveness of pregnant Sudanese women to malarial vector-Anopheles arabiansis. Ann Trop Med Parasitol, 98: 631-633.

Himeidan YE, Malik EM, Adam I. (2005). Epidemiology and seasonal pattern of malaria in an irrigated area of eastern Sudan. Am J infectious diseases, 1: 75-78.

Launiala A, Kulmala T. (2006). The importance of understanding the local context: women's perceptions and knowledge concerning malaria in pregnancy in rural Malawi. Acta Tropica, 98:111-117.

Malik EM, Khalafalla OM. (2004). Malaria in Sudan: past, present and the future. Gezira Journal of Health Sciences 1: (suppl) 47-51.

Mbonye AK, Neema S, Magnussen P. (2006a). Preventing malaria in pregnancy: a study of perceptions and policy implications in Mukono district, Uganda. Health Policy Plan, 21: 17-26.

Mbonye AK, Neema S, Magnussen P. (2006b). Treatment-seeking practices for malaria in pregnancy among rural women in Mukono district, Uganda. J Biosoc Sci, 38:221-237.

Mbonye AK, Neema S, Magnussen P. (2006c). Perceptions on use of sulfadoxine-pyrimethamine in pregnancy and the policy implications for malaria control in Uganda. Health Policy Plan, 77:279-289.

Nuwaha F. (2002). People's perception of malaria in Mbarara,Uganda. Trop Med Int Health, 7:462470.

Parise ME, Ayisi JG, Nahlen BL. (1998). Efficacy of sulfadoxine-pyrimethamine for prevention of placental malaria in an area of Kenya with a high prevalence of malaria and human immunodeficiency virus infection. Am J Trop Med Hyg, 59: 813-822.

Steketee RW, Nahlen BL, Parise ME. Menendez C. (2001). The burden of malaria in pregnancy in malaria-endemic areas. Am J Trop Med Hyg, 64: 28-35.

Ter Kuile FO, Terlouw DJ, Phillips-Howard PA, Hawley WA, Friedman JF, Kariuki SK, Shi YP, Kolczak MS, Lal AA, Vulule JM, Nahlen BL. (2003). Reduction of malaria during pregnancy by permethrin-treated bed nets in an area of intense perennial malaria transmission in western Kenya. Am J Trop Med Hyg, 68 (4 Suppl):50-60. 
Verhoeff FH, Brabin BJ, Chimsuku L, Kazembe P, Russell WN, Broadhead R. (1998). An evaluation of the effects of intermittent treatment in pregnancy on parasite clearance and risk of low birth weight in rural Malawi. Ann Trop Med Parasitol, 92: 141-150. 

Chapter 9

General discussion 


\section{DISCUSSION}

The studies in this thesis investigated different aspects of malaria during pregnancy in Eastern Sudan. The results showed that malaria during pregnancy is a substantial burden since pregnant women in eastern Sudan are susceptible to malaria, both peripheral and placental, and its related anaemia irrespective to their age or parity. While anaemia and low body mass index were found to be risk factors for poor perinatal outcomes, malaria alone was not found to be associated with low birth weight. While both pregnant women and midwifes in the area had good knowledge about malaria and its complications, there was poor knowledge about the effects and use of preventive measures, notably intermittent preventive treatment.

\section{Epidemiology of malraia and anemia in pregnancy}

Most of the studies on epidemiology and pathogenesis of malaria during pregnancy emerged from areas of stable malaria in Africa; while on the other hand data on the treatment of malaria during pregnancy emerged from western border of Thailand, which is characterized by unstable malaria transmission. The studies in Thailand investigated displaced Karen women located in a limited area in camps following local conflict in the area; these condensed living conditions themselves might have influenced the epidemiology of malaria during pregnancy. In the Karen women studied, malaria and malaria-related anaemia affect mainly primigravidae and secundigravidae (Nosten et al., 1991), while malaria and its related anaemia in eastern Sudan affect pregnant women irrespective to their age and parity (Adam et al., 2005a). This might be explained by the relatively high prevalence of malaria among the women in the refugee setting described in the Thailand study $(37.2 \%)$ versus the relatively low prevalence $(13.7 \%)$, especially in the second study (Chapter $3)$, in Eastern Sudan. In addtion, in the study from Thailand most parasitemic women were asymptomatic $(90 \%)$, which suggests that these women had existing antimalarial immunity, which in turn indicates a more stable transmission pattern than in eastern Sudan. Most of the studies in Thailand were community-based (with data obtained in camps), while 5 out of 7 of the studies included in this thesis were hospital-based, which potentially has an inherent bias. Hospital-based studies have several limitations, including not being representative of the disease pattern at the community level. Perhaps women opt for hospital delivery when they anticipate a complicated delivery. Furthermore, while both in Thailand and Sudan P. falciparum are endemic, in Thailand, P. vivax brings also a considerable burden on pregnant women. In summary, it is understandable that the results of the studies conducted in Thailand among Karen women and the studies presented in this thesis do deviate in their results.

In spite of differences, some similarities between data of Thailand and the data of eastern Sudan do exist, such as the existence of severe cases among the pregnant women (Luxemburger et al., 1997; Adam et al., 2004a).

In the first study in this thesis, which was designed mainly to investigate susceptibility of pregnant women in eastern Sudan to malaria, the birth weight of the babies born to infected mothers was significantly lower in comparison to the non-infected group. Although, it had a relatively small sample-size, the findings are in line with those of Nosten et al., who followed the infected women till the delivery and the birth weight was compared between the infected and non-infected women. In a follow-up study, we used malaria placental histopathology, and birth weight was compared between infected and non-infected women. With this design, there was no association between placental malaria and low birth weight. Multiple causes can be taken into consideration to explain these differences. These include submicroscopic malaria infections, stillbirth due to acute malaria, changing treatment for malaria, other infections (e.g. Schistosomiasis) and other confounding factors leading to low birth weight, that were not taken into consideration in our studies.

Several studies have shown that malaria is the most important cause of low birth weight in stable malaria-endemic areas, especially among primigravidae (McGregor, 1984; Brabin \& Piper, 1997). The mean birthweight in all parities was significantly lower at two sites with different transmission in Uganda (Ndyomugyenyi et al., 2001), and that was attributed to frequent and persistent malaria infection in pregnancy leading to maternal anaemia and intra-uterine growth retardation (Kramer, 1987). However, in areas of unstable transmission, acute malaria is common and could lead to abortion, stillbirths or premature delivery (Nosten et al., 1991). The high; rates of stillbirth observed at Kabale hospital compared to Hoima hospital in Uganda (with unstable and stable 
malaria transmission, respectively) support these findings. Malaria has been observed to affect primigravidae more than multigravidae in areas of stable transmission. Therefore, in these areas the influence of malaria infection on birthweight is more significant in primigravidae than multigravidae (McGregor, 1984). However, in areas of unstable malaria transmission, pregnant women of all parities are equally exposed to the risk of malaria and its associated hazards on birthweight owing to lack of sufficient malaria immunity. The rates of low birth weight decreased with parity in the area of stable transmission, but not in an area of unstable transmission (Verhoeff et al., 1999).

Stillbirth is common in areas with unstable malaria (Brabin et al., 2004; Cot and Deloron, 2001; Ndyomugyenyi et al., 2001). Newman et al. (2003) reported a seven-fold increased risk of stillbirth in association with placental parasitaemia in areas with unstable malaria transmission in Ethiopia. The impact of malaria on the risk of stillbirth and neonatal mortality is still under debate. Malaria could increase stillbirth risk through fetal anaemia or preterm delivery (Brabin et al., 1991). However, neither McGregor et al., (1983) in the Gambia, nor Anagnos et al. in Zaire (Anagnos et al., 1986), detected any statistical association between stillbirth and placental malaria. McGregor et al. reported some seasonal differences in stillbirth rates, with the lowest rate occurring during the three months of the late dry season when placental malaria prevalence was low. This difference occurred across all parities. Conversely Okoko et al., (2002) also in the Gambia, observed a twofold increased risk of stillbirth among mothers with malaria-infected placenta. Recently, van Geertruyden et al., (2004) performed a meta-analysis of 17 cross-sectional studies mostly from Africa, and observed on overall odds ratio of stillbirth of 2.19 ( $95 \%$ confidence interval $=1.49-3.22$, $P<0.001)$

In Africa, there have been few studies of malaria during pregnancy in areas of unstable, or epidemic-prone, transmission. One hospital-based retrospective study conducted in 2 different regions of Uganda found that the risk of hospitalization with malaria and the rate of stillbirths were significantly more common in an area of unstable than an area of stable transmission (Ndyomugyenyi et al., 2001). The two cross-sectional studies in Ethiopia found that peripheral parasitemia, as well as placental parasitemia, was very uncommon in areas of unstable transimission during a non-epidemic year and only moderately common in an area of stable but low transmission. However, although rates of parasitemia were relatively low, malaria during pregnancy was strongly and significantly associated with adverse pregnancy outcomes, including maternal anemia, low birth weight, premature delivery, and stillbirths. This in contrast to our findings in eastern Sudan (Chapter 3).

During the conduct of the studies included in this thesis, multidrug resistant $P$. falciparum strains were observed among pregnant and non-pregnant populations in eastern Sudan (the study area) (Adam et al., 2004c ). For this reason, Sudan as well as many other African countries changed their policy in the treatment of malaria from chloroquine to artemisinin based chemotherapy. Artesunate plus sulfadoxine/pyrimethamine is the recommended first line treatment for uncomplicated P. falciparum malaria including pregnant women. Thus, many of these pregnant women were treated effectively and safely with these compounds ( Adam et al., 2006). This might explain the lack of an association in between placental malaria amd low birth weight in our follow up study and might indicate a need to focus attention on other causes of low birth weight.

In the studies included in this thesis, peripheral, placental malaria and anaemia were not associated with age or parity. A plausible explanation includes the low endemic density of malaria during the study period in the area of eastern Sudan. This point needs to be considered in the implementation of the preventive measures for malaria in this vulnerable group. Thus, any preventive measures in eastern Sudan should be directed to all pregnant women irrespective to their age and parity.

Currently, In Africa the impact of malaria on maternal and perinatal outcomes are influenced by infections with the Human Immunodeficiency Virus (HIV). Not only the the bruden of malaria and its unfavourable effects might be higher in the presence of HIV infections, but also its treatment and its prevention (e.g. intermittent preventive treatment) can be negatively influenced too (Parise et al., 1998). These points need to be remembered when comparing the data in this thesis with that of other African countries. The prevalence of HIV among pregnant women of central Sudan was reported to be low (1\%) (Gassmelseed et al., 2006), despite poor knowledge of HIV counseling and 
testing (Mahmoud et al., 2007). Based on the low prevalence of HIV in Sudan, it is unlikely that the results of our studies would have been influenced by prevalent HIV infections.

In this thesis neither cortisol nor prolactin were found to have a role in the pathogenesis of malaria during pregnancy. These findings are not in line with the previous reports from other settings (Bouyou-Akotet et al., 2005). However, consisten with the data from Western and Southern Africa (Loscertales and Brabin, 2006), the susceptibility of pregnant with blood group $O$ to placental malaria has been confirmed in this thesis.

In summary, it seems that many factors intermingle with each other in the pathogenesis and susceptibility of malaria during pregnancy leading to multiple plausible hypotheses to be tested. Effective measures to reduce the burden of malaria in unstable transmission settings would differ from those recommended for high transmission areas. For instance, insecticide-treated bednets were not effective for preventing anaemia in pregnancy in a high transmission area in Kenya (Shulman et al. 1998), while they reduced anaemia in an area of low transmission on the ThaiBurmese border (Dolan et al. 1993). Chemoprophylaxis is effective in reducing the burden of malaria in primigravidae in high endemic areas (Shulman et al. 1999). However, it is not clear whether chemoprophylaxis during pregnancy should be offered routinely in low transmission areas and if so what parities should be targeted.

\section{PUBLIC HEALTH IMPLICATIONS}

Malaria has been reported as an important cause of morbidity and mortality in Sudan (Malik and Khalafalla, 2004). Malaria has deleterious effects on the maternal health.The core of this thesis is the report of the substantial burden of malaria during pregnancy (peripheral and placental malaria) in eastern Sudan, where it affects pregnant women irrespective to their age or parity. Based on these results public health officials, in cooperation with the antenatal clinic workers in Halfa, started implementing preventive measuress including house spraying, insecticide-treated bednet and intermittent preventive treatment to prevent these complications, and especialy anemia. Unfortunately, while both pregnant women and midwifes had a good knowledge about the risks of malaria and recognized its vector, they had a poor knowledge of the effects of the preventive measures, which were consequently underused. These latter findings are of interest for the public health workers, where efforts are needed in many dimensions. Guided by the results of this thesis, preventive measures should be given to all pregnant women in the Halfa area (eastern Sudan) irrespective to their age or parity. However, there is a need for continous health education both to pregnant women and to midiwifes, Future approaches should include not only the provision of preventive measures, but also health education, targeted at increasing knowledge about the effects of preventive measures. Furthermore, in the antenatal care package in those areas where malaria is an important issue routine invesitigation for malaria could be incorporated. Although, this thesis failed to find association between malaria and poor perinatal outcomes, it brought other important factors for poor perinatal outcome to the attention. These are maternal low body mass index and anaemia. Thus, public health workers might be in need to implement more efforts in the field of nutritional health for these women. To our knowledge there is no data cocerning the types of anaemia in Sudan, in pregnant and non- pregnant women. Hence, research into additional contributors to anemia (folate, vitamin B12, iron, other infestations) is urgently needed and could lead to targeted dietary supplements.

\section{IMPLICATIONS FOR FUTURE RESEARCH}

Although studies in this thesis provide additional information on malaria and anaemia during pregnancy in eastern Sudan, still more questions need to be answered. The susceptibility of the pregnant women to malaria need to be investigated in more depth. In other parts of the wolrd the plausible hypothesis of the chondrotin sulfate $A$, has been tested and it is worth to be investigated in this area. The peak time of the malaria during pregnancy, has been found to be in the later second trimester and early third trimester. The susceptibility of malaria has been reported to extend beyond pregnancy, to the postpartum period. The underlying mechanims needs to be investigated in the future and could lead to new insights, not only in pathogenesis, but potentially 
also for other treatment venues. The area of the eastern Sudan is endemic for Schistosomiasis mansoni, which could have its own effects on anaemia and other morbidity during pregnancy, this needs to be considered if anaemia is to be investigated and the overlap with malaria needs to be explored.

The thesis highlighted the poor community reaction to intermittent preventive treatment. However, their effects on malaria and anaemia and pregnancy was not investigated, so this area need to be explored.

A study included in this thesis showed no association between malaria and low birth weight. Low birth weight deserves more elaboration, with regard to other risk factors in relation to malaria, including the role of submicroscopic parasitaemia. An importtant, potentially confounding, issue is stillbirth, which we did not address in the current studies. This confounding factor shoud be adressed in future studies.

Anaemia was shown to be related to poor neonatal outcome, hence other causes of anaemia in these women deserve exploration. Although, pica, which is relatively common in eastern Sudan has been found to be associated with anaemia, its association, whether causative or not, with pregnancy outcomes need to be investigated further.

Anaemia during pregnancy it self, through many endocrine alterations may influence the maternal and fetal environment. Few data exist concerning the role of endocrine factors e.g. prolactin in restricting fetal growth in anaemia during pregnancy (Mahajan et al., 2008). So maternal and fetal endocrine profiles need further exploration.

Recently, reports of associations between malaria and hypertension during emerged from other African seettings (Brabin, 2005). No doubt that hyertension during pregnanacy is another eranda that has asubstantial burden of fetal and maternal morbidity. So it will be worth to invetigate the likagage between hypertension and malaria during pregnancy.

In comclusion, malaria and anaemia are important threaths to maternal and neonatal health in the area of eastern Sudan that was studies in this thesis. Until a complete evidence-based model of epidemiology and pathphysiology is ready, the information in this thesis could be used for the guidance in planning health care provision to to other parts of Sudan as well as for other settings with similar background. 


\section{REFERENCES}

Adam I, Ali DM, Elbashir MI. (2004a). Manifestations of falciparum malaria among pregnant of Eastern Sudan. Saudi Med J, 25: 947-951

Adam I, Osman ME, ElGhazali G, Ahmed GI, Gustafson LL, Elbashir MI. (2004c). Efficacies of chloroquine, sulphadoxine-pyrimethamine and quinine for the treatment of uncomplicated Plasmodium falciparum malaria in Eastern Sudan. Ann Trop Med Parasitol, 98: 661-666.

Adam I, Khamis AH, Elbashir M. (2005a). Prevalence and risk factors for anaemia in pregnant women of eastern Sudan. Trans R Soc Trop Med Hyg, 90 :739-743.

Adam I, Ali D M, Abdalla A. (2006). Artesunate plus Sulfadoxine-pyrimethamine in the treatment of uncomplicated P. falciparum malaria during pregnancy in eastern Sudan. Trans R Soc Trop Med Hyg, 100: 632-636.

Anagnos D, Lanoie LO, Palmieri JR, Ziefer A, Connor DH: Effects of placental malaria on mothers and neonates from Zaire. Z Parasitenkd 1986, 72(1):57-64.

Bouyou-Akotet MK, Adegnika AA, Agnandji ST, Ngou-Milama E, Kombila M, Kremsner PG, Mavoungou E. (2005). Cortisol and susceptibility to malaria during pregnancy. Microbes Infect, 7: 1217-1223.

Brabin BJ: The Risks and Severity of Malaria in Pregnant women. In Applied Field Research in Malaria Reports Volume 1. Geneva: World Health Organization; 1991.

Brabin BJ, Kalanda BF, Verhoeff FH, Chimsuku LH, Broadhead RL: Risk factors for foetal anaemia in a malarious area of Malawi. Ann Trop Paeds 2004, 24:311-321.

Brabin B, J, Peter M, Johnson P M. (2005). Placental malaria and pre-eclampsia through the looking glass backwards? J Reprod Immunol; 65:1-15.

Brabin, B. \& Piper, C. (1997). Anaemia and malaria attributable to low birth weight in two populations in Papua New Guinea. Annals of Human Biology, 24, 547-555.

Cot M, Deloron P: Malaria prevention strategies. Br Med Bull2003, 67:137-48.13.

Diagne N, Rogier C, Sokna CS, Tall A, Fontenille D, Roussilhon C, Trape JF. (2000). Increased susceptibility to malaria during early postpartum period. N Engl J Med 2000; 343: 598-603.

Dolan G, ter Kuile FO, Jacoutot V, White NJ, Luxemburger C, Malankirii L, Chongsuphajaisiddhi T, Nosten F. (1993). Bed nets for the prevention of malaria and anaemia in pregnancy.Trans $R$ Soc Trop Med Hyg.;87(6):620-6

Gassmelseed DE, Nasr AM, Homeida SM, Elsheikh MA, Adam I.(2006) Prevalence of HIV infection among pregnant women of the central Sudan. J Med Virol, 78:1269-1270.

Kramer, M. S. (1987). Determinants of low birth weight: methodological assessment and metaanalysis. Bulletin of World Health Organization, 65, 663-737.

Loscertales MP, Brabin BJ. (2006). ABO phenotypes and malaria related outcomes in mothers and babies in The Gambia: a role for histo-blood groups in placental malaria. Malar J, 5: 72.

Luxemburger C, Ricci F, Nosten F, Raimond D, Bathet S, White NJ. (1997). The epidemiology of severe malaria in an area of unstable and low transmission in Thailand. Trans $R$ Soc Trop Med Hyg, 91: 256-262.

Mahajan SD, Aalinkeel R, Shah P Singh S, Kochupillai N. Nutritional anaemia dysregulates endocrine control of fetal growth. British Journal of Nutrition 2008; 100:408-417.

Mahmoud MM, Naser AM, Gassmelseed DA, Abdalelhafiz MA, Elsheikh MA, Adam I. (2007). Attitude towards HIV and HIV voluntary counselling and testing among pregnant Sudanese women, J Med Virol, 79: 469-473.

Malik EM, Khalafalla OM. (2004). Malaria in Sudan: past, present and the future. Gezira Journal of Health Sciences 1: (suppl) 47-51.

Maubert B, Fievet N, Tami G, Cot M, Boudin C, Deloron P: Development of antibodies against chondroitin sulfate A-adherent Plasmodium falciparum in pregnant women. Infect Immun 1999, 67:5367-5371. 
McGregor IA, Wilson ME, Billewicz WZ.(1983). Malaria infection of the placenta in The Gambia, West Africa; its incidence and relationship to stillbirth, birthweight and placental weight. Trans R Soc Trop Med Hyg. 77;232-44.

McGregor, I. A. (1984). Epidemiology, malaria and pregnancy. American Journal of Tropical Medicine and Hygiene, 33,517-525.

Ndyomugyenyi R, Magnussen P: Malaria morbidity, mortalityand pregnancy outcome in areas with different levels of malaria transmission in Uganda: a hospital record-based study. Trans R Soc Trop Med Hyg 2001, 95(5):463-68.

Newman RD, Hailemariam A, Jimma D, Degifie A, Kebede D, Rietveld AE, Nahlen BL, Barnwell JW, Steketee RW, Parise ME: Burden of malaria during pregnancy in areas of stable and unstable transmission in Ethiopia during a non-epidemic year. J Infect Dis 2003, 187(11):1765-72.

Nosten F, Ter Kuile FO, Maelankirri L, Decludt B, White NJ. (1991). Malaria during pregnancy in an area of unstable endimicity. Trans R Soc Trop Med Hyg, 85: 424-429.

Okoko BJ, Ota MO, Yamuah LK, Idiong D, Mkpanam SN, Avieka A, Banya WA, Osinusi K.(2002). Influence of pacental malaria infection on fetal outcomes in the Gambia: twenty years after I an Mcgregeor. Journal of public health and Nutrition. 20, 4-11.

Parise ME, Ayisi JG, Nahlen BL. (1998). Efficacy of sulfadoxine-pyrimethamine for prevention of placental malaria in an area of Kenya with a high prevalence of malaria and human immunodeficiency virus infection. Am J Trop Med Hyg, 59: 813-822.

Shulman CE, Dorman EK, Tallsuna AO et al. (1998) A community randomized trial of insecticide treated bednets for the prevention of malaria and anaemia among primigravid women on the Kenya coast. Tropical Medicine and International Health 3, 197-204.

Shulman CE, Dorman EK, Cutts F et al. (1999) Intermittent sulphadoxine-pyrimethamine to prevent severe anaemia secondary to malaria in pregnancy: a randomised placebo-controlled trial. Lancet 353, 632-636.

Staalsoe T, Shulman CE, Bulmer JN, Kawuondo K, Marsh K, Hviid L. (2004). Variant surface antigenspecific IgG and protection against clinical consequences of pregnancy-associated Plasmodium falciparum malaria. Lancet, 363(9405):283-289.

van Geertruyden JP, Thomas F, Erhart A, D Alessandro U. (2004). The conribuation of malaria in pregnancy to perinatal mortality. American Journal of Tropical Medicine and Hygiene, 71: 3540.

Verhoeff, F. H., Brabin, B. J., Chimsuku, L., Kazembe, P. \& Broadhead, R. L. (1999). An analysis of the determinants of anaemia in pregnant women in rural Malawi-a basis for action. Annals of Tropical Medicine and Parasitology, 99, 119-133. 



\section{SUMMARY}

The study was conducted in New Halfa area in the eastern Sudan, which is characterized by unstable malaria transmission. The predominant malaria parasite species is Plasmodium falciparum and Anopheles arabiensis is the sole malaria vector in the area. The study aimed to investigate: the susceptibility of pregnant women to malaria in comparsion to non- pregnant controls, the burden of malaria and anaemia and their risk factors among pregnant women, effects of malaria on maternal and perinatal outcomes, pathogenesis of malaria during pregnancy in the area and to investigate ways to prevent malaria in the area.

A longitudinal community- based study was conducted at a village antenatal clinic (Chapter 2), 89 non-pregnant controls and 86 pregnant women were enrolled and followed every 2 weeks until 6 weeks after delivery to investigate the susceptibility of pregnant women to $P$. Falciparum malaria in comparison to their non-pregnant counterparts.

The incidence of $P$. falciparum infection was significantly higher among pregnant than control women $(17.4 \%$ versus $5.6 \%)$ with no difference between primigravidae and multigravidae $(22.2 \%$ versus $15.2 \%)$.

A cross sectional study was conducted (Chapter 3 and 4), where antenatal clinical attendants were investigated for malaria and anaemia and risk factors for these conditions were assessed.. In this group of patients both the prevalence of malaria and its risk factors and the prevalence of anemia was and its risk factors were descibed.

A total 102 (13.7\%) of 744 women had P. falciparum malaria, 18 (17.6\%) of these were severe cases (jaundice and severe anaemia). Univariate and multivariate analysis showed that, age and parity were not associated with malaria. Women who attended the antenatal clinic in the third trimester were at highest risk for malaria $(\mathrm{OR}=1.58,95 \% \mathrm{Cl}=1.02-2.4 ; \mathrm{P}<0.05)$.

Of the 74 women, $466(62.6 \%)$ had anaemia (haemoglobin $[\mathrm{Hb}]:<11 \mathrm{gm} / \mathrm{dl}$ ). $52.4 \%$ had mild anaemia (Hb: 9.0-10.9 gm/dl), 8.1\% had moderate anemia (Hb: 7.0-8.9 gm/dl), and $2.2 \%$ had severe anaemia $(\mathrm{Hb}:<7 \mathrm{gm} / \mathrm{dl})$, respectively. The prevalence of anaemia $(73.2 \%)$ was significantly high in grandmultigravidae. Univariate and multivariate analysis showed that age and parity, were not significantly associated with anaemia. Malaria $(\mathrm{OR}=4.5,95 \% \mathrm{Cl}=2.5-8.1 ; \mathrm{P}<0.0001)$ and pica $(\mathrm{OR}=1.6,95 \% \mathrm{Cl}=1.05-2.6 ; \mathrm{P}=0.03)$ were the risk factors for anaemia.

In a cross-sectional study, parturient women were investigated for anaemia, peripheral and placental malaria (Chapter 5 and 6). The prevalence and risk factors for placental malaria in eastern Sudan were descibed, as well as the effect of malaria and anaemia on maternal and perinatal outcomes.

$114(39.7 \%), 61(22.1 \%)$ and $118(38.2 \%)$ women were primiparae, secundiparae and multiparae, respectively. The $A B O$ blood group distribution was $82(A), 59(B), 24(A B)$ and $128(O)$. Placental histopathology showed acute placental malaria infections in $6(2 \%)$, chronic infections in $6(2 \%), 82$ (28.0\%) of the placentae showed past infection and $199(68.0 \%)$ showed no infection.

There was no association between the age $(O R=1.02,95 \% \mathrm{Cl}=0.45-2.2 ; \mathrm{P}=0.9)$, parity $(\mathrm{OR}=0.6$, $95 \% \mathrm{Cl}=0.3-1.2 ; \mathrm{P}=0.1$ ) and placental malaria infections. In all parity blood group $\mathrm{O}$ was associated with a higher risk of past $(O R=1.9,95 \% \mathrm{Cl}=1.1-3.2 ; \mathrm{P}=0.01)$ placental malaria infection. This was also true when primiparae were considered separately $(O R=2.6,95 \% \mathrm{Cl}=1.05$ 6.5, $\mathrm{P}=0.03$ ).

Among women with all placental infections / past placental infection, the mean haemoglobin was higher in women with the blood group $\mathrm{O}$, but the mean birth weight, feto-placental weight ratio was not different between these groups and the non- $O$ group.

A case- control study was conducted to investigate the role of cortisol and prolactin in the pathogenesis of malaria. There was no significant difference in concentration of total cortisol in pregnant women with malaria in comparison with the control group, and this is true for both primigravidae and multigravidae.

In women with uncomplicated malaria cortisol concentration did not differ significantly between primigravidae and multigravidae (Chapter 7). Cortisol was not correlated with the gravidity, gestational age or initial temperature, but positive correlation was observed in cortisol and parasite count. The total serum prolactin was not significantly different between the infected and non-infected group for both primigravidae and multigravidae. 
Finally, in a community- based survey the perceptions among midwives and pregnant women of the causes of malaria, its complications, its treatment and methods of prevention were assessed (Chapter 8).

More than three quarters (78.2\%) of the midwives and $(82.7 \%)$ pregnant women perceived that mosquitoes were the transmitters of malaria. The coverage of ITNs was $65.5 \%$ among the interviewed pregnant women.

There was poor knowledge about the complications of malaria during pregnancy, and the effect of malaria treatment on the fetus among the interviewed midwives and pregnant women. More than sixty percent, $59(67.8 \%)$ of the midwives and almost all the pregnant women $162(96.4 \%)$ had no knowledge towards the IPT. 


\section{SAMENVATTING}

De onderzoeken gepresenteerd in dit proefschrift zijn uitgevoerd in "New Halfa" in het oosten van Soedan. Het gebied wordt gekenmerkt door onstabiele maliara transmissie. De meest voorkomende malariaparasiet soort in Plasmodium faciparum en de enige malaria vector in het gebied is de Anopheles arabiensis.

De beschreven onderzoeken streefden ernaar: de ontvankelijkheid van zwangere vrouwen voor malaria te vergelijken met niet-zwangere controles, de morbiditeit ten gevolge van malaria en anemie gedurende de zwangerschap te beschijven, in relatie tot de aanwezigheid van risico factoren voor deze condities in het bestudeerde geografische gebied.

Een longitudinaal populatie-gebaseerd onderzoek (Hoofdstuk 2) werd uitgevoerd in een dorpsgebonden prenatale kliniek. Er deden 89 (controle) niet-zwangere vrouwen en 86 zwangeren mee. Deze werden iedere twee weken gevolgd, tot 6 weken na de bevalling van de zwangeren. De incidentie van P. Falciparum infection was significant hoger in zwangeren dan in controles $(17.4 \%$ versus $5.6 \%)$, echter er was geen significant verschil tussen primigravidae (22.2\%) en multigravidae (15.2\%).

In een cross-sectioneel onderzoek (Hoofdstuk 3 en 4) werden zwangeren die een antenatale kliniek bezochten onderzocht op het voorkomen van malaria en anemie en risico-factoren voor deze condities en de relaties tussen deze werden beschreven. Van de 744 zwangere vrouwen hadden er $102(13.7 \%)$ een infectie met P. falciparum. Hiervan waren 18 van de 102 ernstig (geelzucht en ernstige anemie). Univariabele en multivariabele analyses lieten zien dat leeftijd en pariteit niet geassocieerd waren met deze malaria infectie. Zwangeren die in hun derde trimester voor het eerst de antenatale kliniek bezochten hadden het hoogste risico voor malaria $(O R=1.58$, $95 \% \mathrm{Cl}=1.02-2.4 ; \mathrm{P}<0.05)$.

Van de 744 zwangeren leden 466 aan anemie (hemoglobine $<11 \mathrm{gram} / \mathrm{dl}$ ), oftewel 62.6\%. Dit was verdeeld in milde anemie ( $\mathrm{Hb}$ tussen 9.0 en $10.9 \mathrm{gram} / \mathrm{dl} ; 52.4 \%)$, matig ernstige anemie $(\mathrm{Hb}$ tussen 7.0 en $8.9 \mathrm{gram} / \mathrm{dl} ; 8.1 \%$ ) en ernstige anemie ( $\mathrm{Hb}$ onder $7.0 \mathrm{gram} / \mathrm{dl} ; 2.2$ ). De prevalentie van anemie was significant hoger in multi-multigravidae(73.2\%). Univariabele en multivariabele analyses lieten zien dat leeftijd en pariteit niet significant met anemie geassocieerd waren. Malaria $(\mathrm{OR}=4.5,95 \% \mathrm{Cl}=2.5-8.1 ; \mathrm{P}<0.0001)$ en pica $(\mathrm{OR}=1.6,95 \% \mathrm{Cl}=1.05-2.6 ; \mathrm{P}=0.03)$ bleken geassocieerd met anemie.

In een volgende cross-sectionele studie (opnieuw in het oosten van Soedan; Hoofdstuk 5 en 6) werden zwangeren ten tijde van de bevalling omderzocht op anemie, perifere en placentale malaria infectie. De prevalentie en risico-factoren voor placentale malaria werden beschrven en de invloed van placentale malaria en anemie op maternale and perinatale uitkomsten werd in kaart gebracht.

De prevalentie van anemie (73.2\%) was zeer hoog in multi-multigravidae. Univariabele en multivariabele analyses lieten zien dat leeftijd en pariteit niet significant geassocieerd waren met anemie. Echter, malaria $(\mathrm{OR}=4.5,95 \% \mathrm{Cl}=2.5-8.1 ; \mathrm{P}<0.0001)$ en pica $(\mathrm{OR}=1.6,95 \% \mathrm{Cl}=1.05$ 2.6; $\mathrm{P}=0.03$ ) waren significant geassocieerd met anemie. Er bleek geen associatie te bestaan met leeftijd $(\mathrm{OR}=1.02,95 \% \mathrm{Cl}=0.45-2.2 ; \mathrm{P}=0.9)$, pariteit $(\mathrm{OR}=0.6,95 \% \mathrm{Cl}=0.3-1.2 ; \mathrm{P}=0.1)$ of placentale malaria infecties. Onafhankelijk van pariteit was bloedgroep $O$ geassocieerd met een hoger risico op doorgemaakte placentale malaria infecties $(O R=1.9,95 \% \mathrm{Cl}=1.1-3.2 ; \mathrm{P}=0.01)$. Dit verschil bleef bestaan wanneer de analyse werd beperkt tot primiparae $(\mathrm{OR}=2.6,95 \% \mathrm{Cl}=$ $1.05-6.5, \mathrm{P}=0.03$ ).

Bij vrouwen met een placentale infectie (actief of doorgemaakt) was het gemiddelde hemoglobinegehalte hoger bij de groep met bloedgroep $\mathrm{O}$, echter het gemiddelde geboortegewicht, de feuto-placentale gewichts-ratio en het placentale gewicht was niet verschillend.

Een casus-controle onderzoek werd verricht (Hoofdstuk 7) om de potentiële betrokkenheid van prolactine en cortisol bij de pathogfenese van malaria te onderzoeken. Er was geen significant verschil tussen de concentraties van totaal cortisol tussen zwangere vrouwen met en zonder malaria, zowel in primigravidae als in multigravidae. Bij vrouwen met ongecompliceerde malaria was de concentratie van cortisol niet significant verschillend tussen primi- en multigravidae. De cortisol concentratie was niet gecorreleerd met graviditeit, zwangerschapsduur of lichaamstemparatuur bij opname. Wel was een positieve associatie tussen cortisol concetratie en 
geobserveerd aantal parasieten in het bloed. De totale serum prolactine concentratie was niet significant verschillend tussen de geinfecteerde en niet geinfecteerde groep, consistent voor primigravidae en multigravidae.

Tenslotte werden in een populatie-gebaseerde enquete (Hoofdstuk 8) de percepties en kennis bij vroedvrouwen en zwangere vrouwen omtrent de oorzaken van malaria, evenals de complicaties, behandeling en preventie van deze infectie bestudeerd.

Meer den drie-kwart (78.2\%) van de vroedvrouwen en (82.7\%) zwangere vrouwen wisten dat muggen de overbrengers van malaria waren. Ongeveer $65 \%$ van de geinterviewde zwangere vrouwen gebruikten geimpregneerde muskietennetten. De kennis omtrent de mogelijke complicaties van malaria gedurende zwangerschap, de effecten van behandeling, de effecten van malaria op de foetus was slecht, zowel bij vroedvrouwen als bij zwangeren. De meeste vroedvrouwen $68 \%$ en zwangeren (96\%) waren niet bekend met intermitterende prophylactisch behandeling, ter voorkoming van de malaria complicaties. 


\section{CURRICULUM VITAE}

Ishag Adam was born on third January, 1965 in Hajer Elteir, Sudan. He attended at Shendi in Sudan from 1980 to 1983 . He obtained his medical degree in January 1991 from Arab University, Libya. Following that, he worked in a number of different centers in order to gain practical experience. He worked during March 1991 to February 1992 as Internship; Arab Medical University Teaching Hospital, Benghazi, Libya.

Then he worked as S.H.O., Internal Medicine Department and Surgery Department, Wad Medani Hospital, Sudan, during June 1992 to Aug1993.

He obtained clinical MD in obstetrics and gynecology in April 1997 from the University of Khartoum, Sudan. Then immediately he shifted to New Halfa Teaching Hospital, where he has settled for eight years, he has established the unit of clinical research with the collaboration of the Ministry of health and university of Khartoum.

He is married to Ashawag A. Ahmed, vit, and has three children, Mohamed, Mustafa and Rahaf, with whom he resides in Khartoum, Sudan.

Ishag has been in teaching and training of the $5^{\text {th }}$ and $6^{\text {th }}$ year medical students at University of Khartoum. This includes lectures, seminars, and bedside clinical teaching. He is also participating in the teaching and clinical training of residents and postgraduate students who are studding MD Obstetrics and gynecology.

He currently works in a big unit in Khartoum Teaching Hospital. He care for general patients in Obstetrics and Gynecology wards with Emergency 24 hour service one per week. He run one outpatient clinic at Fath AIRahman Albashier referred clinic complex in Khartoum.

Ishag has been supervisor to many MD, theses as:

Hepatitis B virus and hepatitis C virus among Sudanese pregnant women, R. M. Elshiekh.

Anaemia and perinatal outcomes, A. A. Abdereldier.

Determinant of interpregnancy interval, K.S. Elfadeil.

Jaundice among pregnant women, R. E Mahgoub.

Blood group and deep venous thrombosis, A. A Abdeelgadier.

Malaria and antiphospholipids, E. O. Omer.

Malaria and pre-eclampsia, S. M. Ahmed.

Ishag has been external examiner to many MD theses, Sudan Medical Specialization Board like: Misoprostol for induction of labour, vaginal vs. oral route, N. Eltigani. October 2007. Urogenital complications following Cesarean section, M. Elmardi, November 2006. Trial of labour, S. Nour Elien, April 2006. CTG, N. Ahmed, April 2006.

Knowledge and attitude towards HIV voluntary counselling and testing services among pregnant women attending an antenatal clinic in Sudan, A.B. Fazari, December 2006.

Adherence to Artesunate plus sulfadoxine/pyrimethamine, A.M. Abdulsalam, December 2006.

He has been external examiner to many Faculties of Medicine, like University of Juba, Sudan. Febraury 2007. El Imam El amahdi University, Sudan. August 2006. Elzaim Elazhari University, Sudan. July 2006. University of AIGadarif, 2006. Nile Valley University, May, 2006. Kordofan (Obeid) University, April, 2006. Al-Fashir University, April, 2006-until now. University of Gizera, 2006. University of Shendi, 2005. University of Gezira, 2005. University of AIGadarif, 2005. The Academy of Medical Sciences and Technology 2005. Kassala University, 1997-until now.

Co-supervisor to the MD thesis, like: A. S. Ahmed, University of Gezira, completed. M. H. Ahmed, University of Khartoum, completed. A.M. Ibrahim, Department of Medicine, University of Khartoum, completed.

K.H Bakeit, Department of Biochemistry, Faculty of Medicine, University of Khartoum. N.M. Bayoumi, Department of Biochemistry, Faculty of Medicine, University of Khartoum.

I E. Elagib, Department of Biochemistry, Faculty of Medicine, University of Khartoum.

O.E. Fadiel Elseid, Department of Biochemistry, Faculty of Medicine, University of Khartoum. A. A. Daak, Department of Biochemistry, Faculty of Medicine, University of Khartoum. 
Reviewer to the following Journal:

International Journal of Gynecology and Obstetrics 2007 until now.

Journal of Public health, 2007, until now.

Indian Journal of Medical Sciences 2006 until now.

Journal of Pediatrics infectious Diseases 2006 until now.

Saudi Medical Journal, Jan 2003 until now.

Gezira Journal of Health Sciences since August 2004 until now.

Ishag is the Local contact points for CPN-YAS-PRD project June 2007 till now.

Head department of Obstetrics\& Gynecology, Khartoum Teaching Hospital, May -June 2007.

Acting head department of Obstetrics\& Gynecology, Faculty of Medicine, December 2005-Feb 2006.

Head, Department of Obstetrics \& gynecology (3 consultants), New Halfa Teaching Hospital, 1997-till February 2005.

General Director, New Halfa Teaching Hospital (8 consultants), June 2000-March 2002.

General Director, Health affairs, Nahar Atbara, province, 1997-1998.

Field supervisor of a collaborative research project with Dr. MI Elbashir, Department of Biochemistry, Faculty of Medicine, University of Khartoum, supported by Multilateral Initiative on Malaria MIM/TDR/WHO from Sep1999 until now.

Ishag is a member of the following

Sudanese association of Family Planning;

Sudanese association for obstetricians and gynecologists;

Sudanese association of community physicians;

International committee for antimalarial drugs safety and monitoring during pregnancy;

International Federation of Gynecologist and Obstetrician, FIGO;

Fellowship of the Royal Society of Tropical Medicine and Hygiene;

Editorial Board of the Journal of Sudanese community Physicians Association.

Editorial Board of the Sudan Monitor.

Ishag has attended African Meningococcal Carriage Consortium Meeting $21^{\mathrm{ST}}-23^{\mathrm{RD}}$ November 2007, London.

Workshop and proposal development on ACTs in the treatment of Schistosomiasis, Basel, Switzerland 23 August-2 September 2007.

Presenting to the $5^{\text {th }}$ European conference on Tropical Medicine and International Health, 23rd $28^{\text {th }}$ May 20, 2007, Amsterdam, The Netherlands.

Workshop on guidelines and technical advices on ethical, Fedral Ministry of Health, Sudan, March 2007.

FP7 training workshop in Ndola, Zambia, 19-29 February 2007.

Invited participant in the Fifth AMANET Biennial Scientific Conference, 26-28 February 2007, Zanzibar, Tanzania (full support for participation) oral presentation.

Annual meeting on maternal malaria operations group, Cape Town, 26-28 January 2007.

Teleconference on knowledge and familiarity with the treatment of malaria infection in Africa. Data monitor Healthcare, USA 6/8/2006

Teleconference, on Pharmacokinetics of Antimalarial during pregnancy, Oxford University, $12 / 6 / 2006$.

Workshop and Seminar on influence of malaria research on the policy- maker, Sudanese Ministry of Health, 22/3/2006. Oral presentation.

Oral presentation in Fortieth Arab and First African association conference, Khartoum, Sudan, Feb 2006.

Third annual scientific conference of the Academy of Medical Sciences and Technology Sudan, November, 2005.

First conference of the travel medicine and infectious disease, London, U.K, November 2005 an oral prestation. 
Fourth MIM pan- African Malaria International Conference, Yaoundé, Cameroon, November 2005. Poster prestation.

Workshop, Protocol Harmonization for Studies on Home Management of Malaria In Urban Areas, Nairobi, Kenya, 26-29 September 2005.

The International Conference of Infectious Disease and Parasitic infection, September 2005, Marseille, France.

The $5^{\text {th }}$ International Conference of Immunology, July 2002, Stockholm, Sweden.

Workshop on Malaria and pregnancy, Stockholm University, Sweden, July 2002.

The $18^{\text {th }}-20^{\text {th }}$ conferences of Sudanese Society of Obstetricians \& Gynecologists, and oral presentation on Praziquantel for the treatment of Schistosomiasis mansoni during pregnancy Feb 2005, Khartoum Sudan.

Ishag is the principle investigator in the projects entitled:

Prevention of meningococcal carriage by conjugate vaccination in countries of the African meningitis belt Supported by London School of Tropical Medicine, 2007.

Cortisol, prolactin and malaria during pregnancy. Supported by Toronto University, Canada, 2007. Pharmacokinetics of DHA-piperaquine. During pregnancy. Supported by Beijing Holley Cotec Pharmaceutics Co,.Ltd China, 2007.

Maternal and perinatal effects of interpregnancy interval. Supported by Maastricht University, The Netherlands, 2007.

Artesunate plus sulfamethoxypyrazine/pyrimethamine for the treatment of cutaneous leishmaniasis: A double-blind, placebo controlled clinical trial. Supported by Dafra pharma, Belgium, 2007

Multi-center trial: Two regimens of artesunate plus sulfamethoxypyrazine-pyrimethamine versus artemether-lumefantrine for the treatment of uncomplicated Plasmodium falciparum malaria in eastern Sudan. Supported by Dafra pharma, Belgium, 2006-2007.

A midwife-based strategy to increase coverage of pregnant women with intermittent preventive treatment and insecticide treated nets in an irrigated area in Eastern Sudan. Supported by EMRO/WHO, 2006-2007.

A fixed-dose 24-hour regimen of artesunate plus sulfamethoxypyrazine-pyrimethamine for the treatment of uncomplicated Plasmodium falciparum malaria in eastern Sudan, Dafra pharma, Belgium, 2005-2006.

Co-investigator in the project entitled: Home management for malaria Supported by EMRO/WHO, 2006.

Collaborator in the following executed projects:

Quinine for severe falciparum during pregnancy with Prof. Mamoun M. Homeida, supported by EMRO/WHO.

Is Praziquantel safe during pregnancy TDR/WHO supported project with Prof. Mamoun M Homeida.

Epidemiology of Malaria during pregnancy in areas of low and unstable transmission in eastern Sudan, small project supported by EMRO/WHO with Dr. Gehad Elghazali.

Clinical pattern and immunopathology of falciparum malaria in areas of low and unstable malaria transmission in Eastern Sudan. It was a three years project (A00003) supported by Multilateral Initiative on Malaria (MIM), MIM/TDR/WHO, with Prof. Mustafa Idris Elbashir. 



\section{PUBLICATIONS}

Adam, I., Babiker, S., Mohmmed, A., A., Salih, M. M., Martin H Prins, M.H., Zaki, Z. M. (2008). Low body mass index, anaemia and poor perinatal outcome in a rural hospital in eastern Sudan. Journal of Tropical Pediatrics, 54(3):202-204.

Adam, I., Elhardello, O. A., Elhadi, M. O., Abdalla, E., Elmardi, K. A., Jansen, F.H. (2008). Antischistosomal efficacy of artesunate plus sulfamethoxypyrazine-pyrimethamine and artemether-lumefantrine administered as treatment for uncomplicated Plasmodium falciparum malaria. Annals of Tropical Medicine and Parasitology, 102 (1): 39-44.

Adam I., Karsany, MS (2008). Case report: Rift Valley Fever with vertical transmission in a pregnant Sudanese woman. Journal of Medical Virology, 80(5):929.

Comments on the article: Impact of maternal Plasmodium falciparum malaria and haematological parameters on pregnancy and its outcome in southeastern Nigeria by C.J. Unekea et al., J Vector Borne Dis 44, 2008, 285-290.

Haggaz, A. A., Radi, E.A., Adam, I. (2008). High perinatal mortality in Darfur, Sudan. Journal of Materno-Fetal and Neonatal Medicine, (4):277.

Adam, I. Omer, EM, Salih, A., Khamis, Malik. EM. (2008). Perceptions of the causes of malaria and of its complications, treatment and prevention among midwives and pregnant women of Eastern Sudan. Journal of Public Health, 13: 129-132.

Elhassan, E.M., Abubaker M. S, Adam, I. (2008). Sublingual compared with oral and vaginal misoprostol for termination of pregnancy with second-trimester fetal demise. International Journal of Gynecology and Obstetrics, 100 (1): 82-83.

Adam, I., Babiker, S., Mohmmed, A.,A., Salih, M. M., Prins, M.H., Zaki, Z. M. (2007). ABO blood group system and placental malaria in an area of unstable malaria transmission in eastern Sudan. Malaria Journal, 10; 6(1):110.

El Zein, A.M., Bukhari, E.A., Homeida, S., Adam, I. (2007). Stroke in CT-Scan department of Khartoum Hospital, Sudan, Tropical Doctor, 37(4): 244-245.

Adam, I., Radi, E.A., Babiker, S. (2007). Comments on the article: Anaemia and pregnancy outcomes in a South African rural population by L.-J. Van Bogaert. Journal of Obstetrics and Gynaecology 2006; 26(7):617 - 619. Journal of Obstetrics and Gynaecology. 27(7):755

Elsheikh, R. M., Daak, A. A., Elsheikh, M. A., Karsany, M. S., Adam, I., (2007). Hepatitis B virus and hepatitis $C$ virus in pregnant Sudanese women. Virology Journal, 24; 4 (1):104.

Haggaz, A. A., Radi, E.A., Adam, I. (2007). High maternal mortality in Darfur, Sudan. International Journal of Gynecology and Obstetrics. 98 (3): 252-253.

Salah, M.T., Adam, I., Malik, E.M. Care -seeking behaviour for fever in children under five years in urban area in eastern Sudan. Journal of Family \& Community Medicine 2007;13(1): 1-5

Adam, I., Nour B. Y, Ibrahim, E.Y., Almahi, W., A., Omer, E.M., Ali, N. Y. (2007). Cortisol and susceptibility to malaria in pregnant women in an area of unstable malaria transmission in eastern Sudan, International Journal of Gynecology and Obstetrics. 98 (3): 260-261.

Ibrahium, A.M., Kheir, M.M., Osman, M.E., Khalil, IF., Alifrangis, M.M., Elmardi, K.A., Malik, E.M, Adam, I. (2007). Efficacies of artesunate plus either sulfadoxine- pyrimethamine or amodiaquine for the treatment of uncomplicated Plasmodium falciparum malaria in eastern Sudan. Annals of Tropical Medicine and Parasitology, 101 (1): 19-25.

Elhardello, O.A., Adam, E.S., Adam I. (2007). Abdominal wall mycetoma presented as obstructed incisional hernia of cesarean section in eastern Sudan. Infectious Diseases in Obstetrics and Gynecology, 7: 74643.

Elhassan, E.M., Nasr, A. M., Adam, I. (2007). Sublingual compared with oral and vaginal misoprostol for labor induction. International Journal of Gynecology and Obstetrics, 97(2): 153-154.

Mahmoud, M.M., Naser, A.M., Gassmelseed, D.A., Abdalelhafiz, M.A., Elsheikh, M.A., Adam, I. (2007). Attitude towards HIV and HIV voluntary counselling and testing among pregnant Sudanese women, Journal of Medical Virology, 79(5):469-473. 
Abdelrahim, I.I., Adam, I., Elghazali,G., Gustafsson, L.L., Elbashir, M.I., Mirghani, R.A. (2007). Pharmacokinetics of quinine and its metabolites in pregnant Sudanese women infected with Plasmodium falciparum malaria. Journal of Clinical pharmcy and Therapeutics, 32 (1); 15-19.

Himeidan, Y.E., Hamid, E., Rayah, E., Elbashir, M. I., Adam, I. (2007). Climatic variables and transmission of malaria: A 17-years data analysis in New Halfa Area in the Eastern Sudan. East Mediterranean Health Journal, 13 (1): 17-24.

Adam, I., Adam, E.S (2007). Spontaneous splenic rupture in pregnant Sudanese woman with falciparum malaria. Eastern Mediterranean Health Journal, 13(3): 735-736.

Haroun, S.A., Elnaiem, E.A., Zaki, Z. M., Adam, I. (2007). Aggressive rhabdo-myosarcoma of the vulva in a young Sudanese woman: a case report. Saudi Medical Journal, 28(3): 461-462.

Haroun, S. A., Radi, E.A., Adam, G. K., Adam, I. (2007). Maternal death due to severe pulmonary edema caused by scorpion sting: a case report. Sudan Medical Monitor, 2 (1): 37-38.

A/Magid Y., M.,. Elussein, E., A., Omer, M., M., Samaan, S.I., A/Rahim, F. Adam, I. (2007). Heparin and aspirin in pregnant Sudanese women with recurrent miscarriage associated with antiphospholipid antibodies. African Journal of Reproductive Health, 11 (2):95-98.

Adam, I. Ali, D. M., Abdalla, A. (2006). Artesunate plus Sulfadoxine-pyrimethamine in the treatment of uncomplicated P. falciparum malaria during pregnancy in eastern Sudan. Transactions of the Royal Society Tropical Medicine and Hygiene, 100: 632-636.

Adam, G. K., Hussein S. M., Adam I. (2006). Renal failure and neonatal death following snakebite during pregnancy. Case report. Journal of Venomous Animal and Toxins including Tropical Diseases 12 (4), 653-656

Adam, I., Magzoub, M.M., Osman, M.E., Khalil, I.F., Alifrangis, M., Elmardi, K.A., Malik, E.M. (2006). A fixed-dose 24-hour regimen of artesunate plus sulfamethoxypyrazine-pyrimethamine for the treatment of uncomplicated Plasmodium falciparum malaria in eastern Sudan. Annals of Microbiology and Antimicrobials, 5 (1):18.

Gassmelseed, D.E., Nasr, A.M., Homeida, S.M., Elsheikh, M.A., Adam I. (2006). Prevalence of HIV infection among pregnant women of the central Sudan. Journal of Medical Virology. 78(10):1269-1270

Salah, M. T., Faroug, M., Magzoub, M. M, Adam I. (2006). Efficacy of artemether-lumfantrine (CoArtesiane $\left.{ }^{\circledR}\right)$ suspension in the treatment of uncomplicated Plasmodium falciparum malaria among children under 5 years in eastern Sudan. Tropical Journal of Pharmaceutical Research. 5(1): 551-555.

Rahama, A.M., Kheir, M.M., Adam I. (2006). Intramuscular artemether in the treatment of uncomplicated Plasmodium falciparum malaria in Sudanese patients. Saudi Medical Journal, 27(1): 122-123.

A-Elgadir, T.M., Theander, T.G., Elghazali, G., Nielsen, M.A., A-Elbasit, I.E., Adam I., TroyeBlomberg, M., Elbashir, M.I., Giha, H.A. (2006). Determinants of Variant Surface Antigen Antibody Response in Severe Plasmodium falciparum Malaria in an Area of Low and Unstable Malaria Transmission. Scandinavian Journal of Immunology, 63(3):232-340.

Adam, I., Zaki, Z.M. (2006). Antimalarials during pregnancy: A review article, Sudanese Journal of Public Health. 1(1): 7-12.

Elbashir, M.l., Adam, I. (2006). Resistance of P. falciparum to antimalarial drugs in Sudan: Review. Khartoum Medical Journal, 1: 3-16.

Ahmed, M.I., Salih, A., Adam, I. (2006). Knowledge and attitude of women towards malaria during pregnancy in central Sudan. Sudan Monitor, 1(2), 57-60.

Elhassan, E., Mirghani, O., Adam, I. (2005). Misoprostol vs. oxytocin for induction of labor. International Journal of Gynecology and Obstetric, 91(3):254-255.

Elamin, S.B., Malik, E.M., Abdelgadir, T., Khamiss, A.H., Mohammed, M.M., Ahmed, E.S., Adam, I. (2005).Artesunate plus sulfadoxine-pyrimethamine for treatment of uncomplicated Plasmodium falciparum malaria in Sudan. Malaria Journal, 14 (4) 41. 
Himeidan, Y.E., Malik, E.M., Adam, I. (2005). Epidemiology and seasonal pattern of malaria in an irrigated area of eastern Sudan. American Journal of infectious diseases, 1(2): 75-78.

Adam, I., Khamis, A.H., Elbashir, M I. (2005). Prevalence and risk factors for malaria in pregnant women of eastern Sudan. Malaria Journal, 4, (1) 8.

Adam, I., Salih, I., Elbashir, M.I. (2005). Quinine for the treatment of uncomplicated Plasmodium falciparum malaria in eastern Sudan. Transactions of the Royal Society Tropical Medicine and Hygiene, 90 (10): 736-738.

Adam, I., Khamis, A.H., Elbashir, M.I. (2005). Prevalence and risk factors for anaemia in pregnant women of eastern Sudan. Transactions of the Royal Society Tropical Medicine and Hygiene, 90 (10): 739-743.

Mamoun, N., Homeida, S., Mabyou, M., Ahmed, H. M., Salah, M. T., Adam, I. (2005). Prevalence, types and risk factors for malnutrition in displaced Sudanese children. American Journal of Infectious Disease, 1(2): 84-86.

Giha, H.A., ELGhazali, G., Elhassan, T.M., Eltayib, I., Eltahir, E.M., Baraka, O.M., Khier, M.M., Adam, I., Blomberg, M.T., Theander, T.G., Elbashir, M.I. (2005) Clinical pattern of severe P. falciparum malaria in Sudan in an area characterized by seasonal and unstable malaria transmission. Transactions of the Royal Society Tropical Medicine and Hygiene, 99, 4: 243-251.

Adam, I., Abdalla, M.A. (2005). Is meningococcal polysaccharide vaccine safe during pregnancy? Annals of Tropical Medicine and Parasitology, 99(6): 627-629.

Adam, I., A/Elbasit, I., Idris, S.M., Malik, E. M., Elbashir, M. I. (2005). A comparison of the Efficacies of artesunate plus sulfadoxine-pyrimethamine versus sulfadoxine-pyrimethamine alone, in the treatment of uncomplicated P. falciparum malaria in eastern Sudan. Annals of Tropical Medicine and Parasitology, 99 (5): 449 -455.

Adam, I., Ali, D.M., Noureldin, W., Elbashir, M.I. (2005).Quinine for treatment of chloroquineresistant falciparum malaria in pregnant and non-pregnant Sudanese women. Annals of Tropical Medicine and Parasitology, 99 (4):427-429.

Adam, I., A/Elbasit I.E., Salih, I., Elbashir, M.I. (2005). Submicroscopic Plasmodium falciparum infections during pregnancy, in an area of Sudan with low malaria transmission. Annals of Tropical Medicine and Parasitology, 99(4):339-344.

Adam, I., A/Elbasit, I., Elbashir, M. I. (2005). Efficacies of mefloquine alone and artesunate followed by mefloquine for the treatment of uncomplicated Plasmodium falciparum malaria in eastern Sudan. Annals of Tropical Medicine and Parasitology, 99 (2): 111-117.

Adam, I., Elwasila, E., Homeida, M. (2005). Praziquantel for the treatment of Schistosomiasis mansoni during pregnancy, Annals of Tropical Medicine and Parasitology, 99 (1): 37-40.

Elhassan, E., Mirghani, O.A., Adam, I. (2005). Cervical ripening and labor induction with 25 micrograms versus 50 micrograms of intravaginal misoprostol. International Journal of Gynecology and Obstetric, 99(4):339-344.

Adam, I., Hassan, O.A, Elhassan, E.M. (2005). Oral misoprostol vs. vaginal misoprostol for cervical ripening and labor induction. International Journal of Gynecology and Obstetrics, 89 (2): 142 143.

Adam, I., Gerais, A. (2005). Abruptio placentae following snake bite in a Sudanese woman. Saudi Medical Journal, 26 (4):686-687.

Adam, I., Adam, E.S., Gerais, A. (2005). Randomized trial of ceftriaxone prophylaxis in elective caesarean section. Saudi Medical Journal, 26 (3), 500-501.

El Imam, M., EL Hassan, E.M., Adam, I. (2005). Vesicovaginal fistula in Sudanese women. Saudi Medical Journal, 26, (2): 341-342.

Salah, M.T., Mohammed, M.M., Himeidan, Y.E., Malik, E.M., Elbashir, M.I., Adam, I. (2005). A randomized comparison of sulphadoxine-pyrimethamine and combination of sulphadoxinepyrimethamine with chloroquine in the treatment of uncomplicated falciparum malaria in Eastern Sudan, Saudi Medical Journal, 26(1): 147-148. 
Giha, H.A., A-Elbasit, I.E., Elgadir, T. M., Adam, I., Berzins, K., Elghazali, G., Ebashir, M.I. (2005). Cerebral malaria is frequently associated with latent parasitemia among the semi-immune population of eastern Sudan. Microbes and Infection, 7(11-12):1196-1203.

Adam, l., Elbashir, M.I. (2005). Comments on "Risk factors for malaria infection and anemia for pregnant women in the Sahel area of Bandiagara, Mali" by A. Dicko et al. [Acta Trop. 89 (2003) 17-23]. Acta Tropica, 96 (1):60-61.

Himeidan, Y.E., Elbashir., M.I., ELRayah, E., Adam, I. (2005). Epidemiology of malaria in an irrigated area in the eastern Sudan. Eastern Mediterranean Health Journal, 11: (3) 499-504.

Adam, I., Elwasila, E., Homeida, M. (2004). Is praziquantel safe during pregnancy? Transactions of the Royal Society Tropical Medicine and Hygiene, 98 (9):540-543.

Adam, l., Elwasila, E., Ali, D.M., Elansari, E., Elbashir, M.I. (2004). Artemether in the treatment of falciparum malaria during pregnancy in Eastern Sudan. Transactions of the Royal Society Tropical Medicine and Hygiene, 98 (9): 509-513.

Homieda, M., Adam, I. (2005). Health in Post-Conflict Southern Sudan. British Medical Journal (rapid response) 25 July.

Hamza, A.M., Himeidan, Y. E., Adam, I., El Rayah, E. (2005). The ecology of A. Arabiensis and isectiside reistance/susceptibility status in Kassala area, eastern Sudan. Gezira Journal of Health Sciences, 1 (2): 46-54.

Adam, I., ElGhazali, G., Elbashir, M.I. (2005). Anaemia among pregnant women of Eastern Sudan, Gezira Journal of Health Sciences, 1 (2): 183-186.

Adam, I., Elbashir, M.I. (2004). Maternal death due to severe pulmonary edema caused by falciparum malaria: Case report. Eastern Mediterranean Health Journal, 10, (4-5): 685-688.

Adam, I., Ibrahim, M.H., A/elbasit, I.A., Elbashir, M.I. (2004). Efficacy of sulfadoxine- pyrimethamine for uncomplicated Plasmodium falciparum malaria in a small sample of Sudanese children. Eastern Mediterranean Health Journal, 10:309-314.

Ahmed, E.S., Mirghani, O.A, Gerais, A., Adam, I. (2004). Ceftriaxone versus ampicillin/cloxacillin as antibiotic prophylaxis in elective caesarean section. Eastern Mediterranean Health Journal, 10: 277-282.

Adam, I., Ibrahim, M.H., A/Elbasit, I., Elbashir, M.I. (2004). Low- dose quinine in the treatment of chloroquine-resistant falciparum malaria in Sudanese pregnant women. Eastern Mediterranean Health Journal, 10, (4-5): 554-559.

Adam, l., Idris, H.M., Elbashir, M.I. (2004). Quinine treatment for chloroquine-resistant falciparum malaria in Sudanese women in the first trimester of pregnancy. Eastern Mediterranean Health Journal, 10, (4-5): 560-565.

Adam, I., ElGhazali, G., Mohamedin, M., Elbashir, M.I. (2004). Anaemia in Pregnant Sudanese Women: Community-Based Study. Saudi Medical Journal, 25 (8): 1119-1120.

Adam, l., Elbashir, M.I. (2004). Acute gluteal abscess due to chloroquine injection in Sudanese pregnant woman. Saudi Medical Journal, 27 (7): 963-964.

Himiedan, Y.E., Elbashir, M.I., Adam, I. (2004). Attractiveness of pregnant Sudanese women to malarial vector-Anopheles arabiansis, Annals of Tropical Medicine and Parasitology, 98 (6): 631-633.

Ibrahim, M.H., Elbashir, M.I, Nasr, A.M., A/Elbasit, I.E., Kheir, M.M., Adam, I. (2004). Low-dose quinine is effective in the treatment of chloroquine-resistant falciparum malaria in Eastern Sudan. Annals of Tropical Medicine and Parasitology, 98 (4): 441-445.

Adam, I., Osman, M.E, ElGhazali, G., Ahmed, G.I., Gustafson, L.L., Elbashir, M.I. (2004). Efficacies of chloroquine, sulphadoxine-pyrimethamine and quinine for the treatment of uncomplicated Plasmodium falciparum malaria in Eastern Sudan. Annals of Tropical Medicine and Parasitology, 98, (7): 661-666

Adam, I., Elbashir, M.I. (2004). Extrapyramidal syndrome after treatment of P. falciparum malaria with sulphadoxine-pyrimethamine. Saudi Medical Journal, 25, (9): 1303-1304. 
Adam, I., Mirghani, O.M., Saed, O.K., Ahmed, S.M., Mohamadani, A.A., Ahmed, H.M., Mackenzie, C.D., Homeida, M.M., Elbashir, M.I. (2004). Quinine therapy in severe Plasmodium falciparum malaria during pregnancy in Sudan. Eastern Mediterranean Health Journal, 10, (1-2): 159-166.

Himeidan, Y., El-Rayah., E., Adam, I. (2004). Anopheles arabiensis: and insecticide resistance status in an irrigated area of eastern Sudan. Eastern Mediterranean Health Journal, 10, (1-2): 176175.

Adam, I., Ali, D.M., Elbashir, M.I. (2004). Manifestations of falciparum malaria among pregnant of Eastern Sudan. Saudi Medical Journal, 25 (12): 947-951.

Adam, I., Ali, D.M., Alwasila, A., Kheir, M.M., Elbashir, M.I. (2004). Mefloquine in the treatment of falciparum Malaria during pregnancy in the Eastern Sudan. Saudi Medical Journal, 25 (10): 400-402.

Adam, I., Elbashir, M.I. (2004). Suicide after treatment of chloroquine-resistant falciparum malaria with quinine. Saudi Medical Journal, 25 (2): 248-249.

Elhassan, E., Mirghani, O.A., Adam, I. (2004). Intravaginal misoprostol vs. dinoprostone as cervical ripening and labor-inducing agents. International Journal of Gynecology and Obstetrics, 85: 285-286.

Fadalla, F., Mirghani, O. A., Adam, I. (2004). Oral misoprostol vs. vaginal misoprostol for termination of pregnancy with intrauterine fetal demise in second-trimester. International Journal of Gynecology and Obstetrics, 86: 52-53.

Elnahas., A, Gerais, A., Elbashir, M.I., Sierag Eldien, E., Adam, I. (2003). Toxoplasmosis in Pregnant Sudanese Women. Saudi Medical Journal, 24 (8): 868-870.

EIGhazali, G., Adam, I., Hamad, A.A., Elbashir, M. I. (2003). Malaria and pregnancy in an area of unstable transmission in eastern Sudan. Eastern Mediterranean Health Journal, 9: 571-580.

Hagaz, A.A., Mirghani, O., Adam, I. (2003). Venous thromboembolism in pregnancy and puerperium in Sudanese women. International Journal of Gynecology and Obstetrics, 83 (3): 309-310.

Abdalla, I.A., Ahmed, S.M., Elhassan, E.M., Mirghani, O.A., Adam, I. (2003). Instrumental operative vaginal deliveries: Vacuum extraction compared with forceps delivery at Wad Medani Teaching Hospital, Sudan. Gezira Journal of Health Sciences, 1: 38-45.

Adam, I., Idris, H., Mohamed-Ali, A.A., A/elbasit, I.A., Elbashir, M.I. (2002). Quinine versus artemether in the treatment of severe falciparum malaria in Sudanese children. East African Medical Journal, 79: 621-625.

Elhassan, E., Mirghani, O., Habour, A., Adam, I. (2002). Methyldopa versus no treatment in mild Preeclampsia. East African Medical Journal, 79: 69-73.

Adam, I., Osman, M.E., Ahmed, G.I., Elbashir, M.I. (2001). In the Sudan: Quinine resistance is emerging and chloroquine resistance is worsening. Sudan Medical Journal, 39: 5-11.

Adam, I., Radi, E., A., Babiker, S. (2007). Comments on the article: Anaemia and pregnancy outcomes in a South African rural population by L.-J. VAN BOGAERT. Journal of Obstetrics and Gynaecology, 2006; 26(7): 617 - 619.

Adam, I. (2007). Comments on the article: The safety of artemisinins during pregnancy: a pressing question by Dellicour et al., Malaria Journal 2007, 6:15.

Ibrahim, E. A., Kheir, M. M, Elhardello, O. A., Almahi, W. A, Ali, N. I., Adam, I. Cortisol and uncomplicated Plasmodium falciparum malaria in an area of unstable malaria transmission in eastern Sudan, submitted.

Elussein, E. A., Magid, Y.M., Omer, M.M., Adam, I. Clinical patterns and major causes of infertility among Sudanese couples. Tropical Doctor, in press.

Bayoumi, N., Hussein, K., Mohmmed, A.A., Mohmedain, A., Elbashier, M.I., Mavoungou E., Adam I. Cytokine profiles in peripheral, placental and cord blood in an area of unstable malaria transmission in eastern Sudan, Journal of Tropical Pediatrics, online.

Hussein, K., Bayoumi, N., Mohmmed, A. A., Mohmedain, A., Elbashier, M.I., Adam I. Cytokines profile in Sudanese women with preeclampsia. Hypertension in pregnancy, accepted. 
Hussein, K., Bayoumi, N. K., Adam I., Peripheral, placental and cord cytokines profile in spontaneous labor and elective caesarean section. Iranian Journal of immunology, accepted.

Ahmed, R. E., Karsany, M. S., Adam, I. Acute viral hepatitis and poor maternal and perinatal outcomes in pregnant Sudanese women. Journal of Medical Virology, in press.

Adam, G. K., Elhassan E. M., Abedaziz A. M., Adam, l., Maternal and perinatal outcome in teenage pregnancies in Sudan. Journal of Pediatrics and Adolescent Gynecology, in press.

Haggaz, A. D., Ahmed, S., Adam, I. Use of antenatal care in Darfur, Sudan. International Journal of Gynecology and Obstetrics, in press.

Adam, I., Elmardi, K. A., Malik, E.M. Predictors of antimalarial treatment failure in an area of unstable malaria transmission in eastern Sudan. Transactions of the Royal Society of Tropical Medicine and Hygiene, in press.

Adam, I. Comments of the article: No evidence for implication of quinine treatment failure in development and fatality of cerebral malaria in Eastern Sudan by Giha et al., International Journal of Antimicrobial Agents, in press.

Ali, E. Y., Adam G. K., Ahmed, S., Ali, N. I., Adam, I. Maternal and Neonatal Hormonal Profiles in Anaemic Pregnant Women of Eastern Sudan, submitted.

Bayoumi, N., Elhassan E.M., Elbashier, M.I., Adam I. Prolactin, cytokines and susceptibility of pregnant Sudanese women to plasmodium falciparum malaria, submitted.

Abdelrahim, I.I., Adam G.K, Mohmmed, A.A., Salih, M.M., Elbashir, M.I Adam, I. Anaemia, folate and vitamin $B 12$ deficiency among pregnant women in an area of unstable malaria transmission in eastern Sudan, submitted.

Adam, I., Adam G. K., Mohmmed, A.A ., Salih, M.M., Ibrahuim, S.A., Anthony, R.C., Lack of antenatal care and placental malaria in an area of unstable malaria transmission in eastern Sudan, submitted.

Adam I, Ismail M. H., Nasr, A. M., Prins, M.H., Smits L.J. Low birth weight, preterm birth and short interpregnancy interval in Sudan. Journal of Materno-Fetal and Neonatal Medicine, accepted.

Gader, A.A., Abed Elrahium, D. Haggaz, A.D., Adam, I. Epidemiology of deep venous thrombosis during pregnancy and puerperium in Sudanese women, submitted. 